De bestudering van het Nieuwe Testament aan de Noordnederlandse universiteiten en het Remonstrants Seminarie van 1575 tot 1700

\title{
$I^{5}$ KAIN N \\ $\Delta \mathrm{IAOH}$ \\ - Noran \\ Teftamencum。
}

Ex̀ Reghis atiisoque optimis editionibus, hat

"nova expreffum: cuiquid accefferit. Prafatio docsbits.

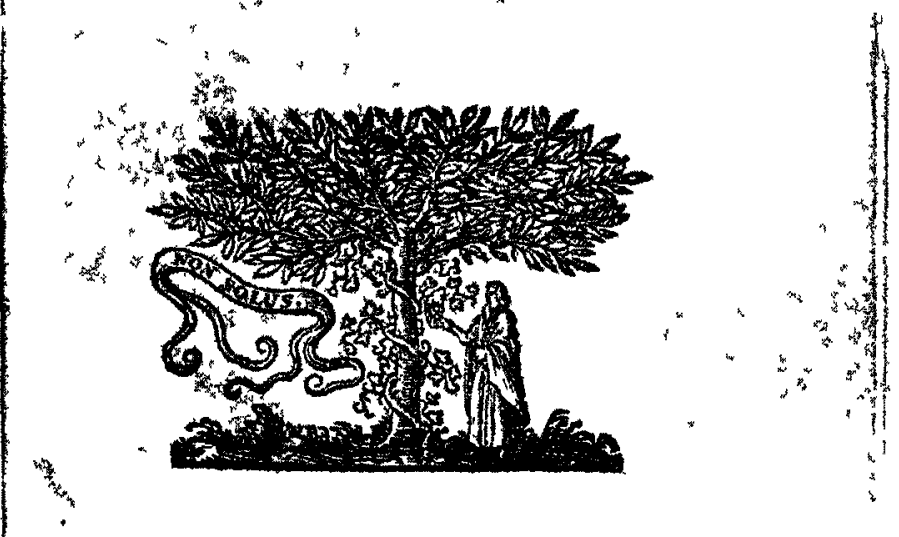

47 20.

Ex Officina Elzeviriorum.

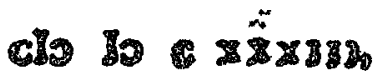

H.J. de Jonge 

De bestudering van het Nieuwe Testament aan de Noordnederlandse universiteiten en het Remonstrants Seminarie 


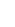




\section{De bestudering van het Nieuwe Testament aan de Noordnederlandse universiteiten en het Remonstrants Seminarie van 1575 tot 1700}

H. J. de Jonge

Verhandelingen der Koninklijke Nederlandse Akademie van

Wetenschappen, Afdeling Letterkunde, Nieuwe Reeks, deel 106

Noord-Hollandse Uitgevers Maatschappij

Amsterdam/Oxford/ New York, 1980 
Aangeboden in de vergadering van de Afdeling Letterkunde van 11 juni 1979 door Prof. Dr. S. Dresden en Prof. Dr. C.C. de Bruin ISBN 0444855017 


\section{Inhoud}

Voorwoord 7

\section{Dogmatische en filologische interesse in het Nieuwe Testament 11}

Onderwijs in een dogmatisch leersysteem tijdelijk uitgesloten 11 , evenals elders 12 , deste meer dogmatische interesse in de exegese 13 , de scholastieke inslag daarvan 14 , de hermeneutische achtergrond 14, de sociologische achtergrond 16, het vrijwel ontbreken van specifieke leeropdrachten Nieuwe Testament 16, ondogmatische interesse in de bijbel bij filologen 17 .

\section{Tekstkritiek en edities van oude vertalingen 21}

Aandacht voor patristische bijbelcitaten bij Scaliger en Coddaeus 21, een briljante conjectuur van Scaliger op Philip. $2: 30$ 22, heerschappij van de textus receptus 22, hoe Hoelzlin de tekst van Elzevier 1633 uitgaf 22, conservatisme bij Daniël Heinsius 23, en Rivetus 23, varianten verzameld door Thysius sr. 24, en Curcellaeus 24, consequentere kritische zin bij Clericus 24 , belangrijke edities van oude vertalingen 26

\section{Het Grieks van het Nieuwe Testament 29}

Het onderwijs Grieks voor theologen 29, Amama's actie, 29, hoogleraren Grieks doceren nieuwtestamentisch Grieks 29, leermiddelen 30, Pasor, zijn woordenboeken 30 , en grammatica 31, twist tussen Salmasius en Heinsius over de dialectus hellenistica 32 , hebraïsten en puristen 35 , het gematigd purisme mondt uit in de observationes-literatuur 37.

\section{De filologische verklaring van het Nieuwe Testament 39}

De annotationes-commentaar vergeleken met de dogmatische commentaar 39 , als antiek vergelijkingsmateriaal benut Drusius vooral judaica 41 , De Dieu oude vertalingen 47, Dan. Heinsius onder meer de exegese der patres 51, andere annotatores: Grotius 54, exegetische compilaties 55, Clericus 55 
V. Harmonistische en oudheidkundige verhandelingen

over Nieuwtestamentische stof 56

De genealogie van Jezus 56, Schoockius over de Asiarchen 57, Spanheim over Petrus te Rome 57, Gronovius en Perizonius over Judas' dood 58, Perizonius over Augustus' volkstelling 58, en over het praetorium in Philip. $1: 13$ 59, Witsius en A Marck 59, incidentele literair-historische kritiek bij Scaliger, Salmasius en Clericus temidden van heersend harmonisme en historisering 60

VI. Vroegchristelijke letterkunde 63

De datering van enige geschriften ingrijpend gewijzigd door Scaliger 63, Polycarpus en Barnabas uitgegeven uit een codex Salmasianus 63, beide uitgegeven en gecommentarieerd door Le Moyne 64, Clericus' uitgaven van de Apostolische Vaders 66

Conclusie 67

Appendix I. De vermeende rol van G. Voetius in de polemiek over het Hellenistisch Grieks 69

Appendix II. Het oordeel van Van Unnik over Grotius als uitlegger van het Nieuwe Testament 72

Appendix III. De noten op het Nieuwe Testament van Josephus Scaliger 77

Appendix IV. Een officieel standpunt van de Leidse theologische faculteit inzake de aard van het Nieuwtestamentisch Grieks (1637) 82

Summary $8 \dot{4}$

Bibliografie 85

Verantwoording van de illustraties 92

Index locorum 94

Index nominum 95

Index variorum 98 


\section{Voorwoord}

In de reeds lang bestaande behoefte aan een geschiedenis van de nieuwtestamentische wetenschap heeft W. G. Kümmel in 1958 tot op zekere hoogte voorzien met zijn werk Das Neue Testament. Geschichte der Erforschung seiner Probleme $\left(1970^{2}\right)$. Dit boek behandelt de geschiedenis van de bestudering van het Nieuwe Testament van Marcion tot Bultmann. Pas vanaf het midden der achttiende eeuw echter wordt deze geschiedenis bij Kümmel een werkelijk samenhangende, doorlopende ontwikkelingsgang. Uit de zestien eeuwen tot Bengel, Wettstein en Semler, een periode die in slechts 50 van de 600 bladzijden wordt afgedaan, geeft Kümmel niet meer dan een aantal grepen. Deze aanpak mag door het oogmerk waarmee hij het boek schreef voldoende worden gerechtvaardigd, het desideratum van een geschiedenis der nieuwtestamentische wetenschap is daarmee althans voor de tijd tot 1750 nog niet vervuld.

Ook in de meeste andere boeken en studies over de geschiedenis van de bestudering van het Nieuwe Testament laat de behandeling van vroegere fasen, met name van de $16 \mathrm{de}$ en $17 \mathrm{de}$ eeuw, te wensen over. W. F. Howard bij voorbeeld beschreef in The Romance of New Testament Scholarship (1949) de tijd van Hiëronymus tot F.C. Baur in de volgende zin: 'For fourteen centuries the critical study of the New Testament runs into a tunnel'.

Dat veel overzichten over de geschiedenis van de nieuwtestamentische wetenschap juist in hun beschrijving van de 17 de eeuw tekort schieten, valt intussen niet te verwonderen. De nodige voorstudies zijn schaars. Algemeen wordt erkend, en met recht, dat Hugo Grotius de belangrijkste uitlegger van het Nieuwe Testament in de 17 de eeuw is geweest. Verscheidene auteurs weten nog te melden, dat Joseph Scaliger zijn leermeester was. Maar hoeveel de laat-humanistische wetenschappelijke traditie van Noord-Nederland, waarin Grotius stond, ook vóór en na hem voor het Nieuwe Testament heeft betekend, is weinig onderzocht en daardoor in moderne geschiedenissen der exegese op ontoereikende wijze beschreven.

De belangrijke, doch langzamerhand onbekend geworden episode der wetenschap die de nieuwtestamentische studiën in Noord-Nederland van Drusius tot Clericus hebben gevormd, is het onderwerp van de volgende schets. Het is een onderwerp dat even goed in tien als in duizend bladzijden kan worden behandeld. De onderhavige bijdrage beoogt niet te uitvoerig en niet te onvolledig te zijn. 
De beschrijver van zelfs de beperkte episode die hier aan de orde is staan zo talrijke en zo omvangrijke bronnen ter beschikking, dat zijn onderzoek onmogelijk ooit exhaustief zal kunnen zijn. Naast een menigte gedrukte werken over, en commentaren op het Nieuwe Testament, zijn er collegedictaten, gepubliceerde en ongepubliceerde correspondenties, libri annotati en adversaria. Het aantal gedrukte bronnen is niet goed te begrenzen: in boeken waarin men het het minst verwacht komen de belangwekkendste uitlatingen over het Nieuwe Testament voor. Voorts is de grens tussen werken over het Nieuwe Testament en die van oudheidkundige en dogmatische aard moeilijk te trekken. Bovenal echter waren 17 de-eeuwse theologen auteurs van lijvige boekwerken. Ze lieten niet graag iets aan de intuïtie van hun lezers over en kenden evenmin de aanvechting om kort van stof te zijn. Wie slaat in de kolossale folianten, waarvan ze er makkelijk een stel vol schreven, niet eens twee bladzijden tegelijk om?

De volgende beschrijving berust daarom noodzakelijkerwijs op een keuze uit het beschikbare bronnenmateriaal. Die keuze werd veelal gedaan ten gunste van hetgeen methodisch van duurzaam belang was. Maar wàt precies van duurzaam belang was, staat niet objectief vast; het wordt als zodanig gewaardeerd. Aan de gemaakte keuzen gaat onvermijdelijk een waardeoordeel vooraf - het zal de lezer van de volgende bladzijden niet óntgaan.

Tenslotte, men kan een geschiedenis van het bijbelonderzoek natuurlijk zo schrijven, dat daarin opnieuw de namen domineren van hen die reeds in brede kringen van hun tijdgenoten als de voornaamste vertegenwoordigers van deze wetenschap golden. Maar men kan ook met de meerderheidsopvattingen van de beschreven tijd wat minder rekening houden, zelf bepalen wat in die periode wetenschappelijk het beste gehalte had en aan dit laatste reliëf geven ten koste van hetgeen eertijds prevaleerde. Zo'n geschiedenis met gewijzigd reliëf zal men hier aantreffen. Mannen als Rivetus, Van Limborch, Jacobus Alting en Witsius zullen enigszins wijken voor zulke als Drusius, De Dieu en Heinsius, om slechts enkele namen te noemen. Coccejus doet een stap terug, Clericus een stap voorwaarts, Scaliger twee. Zo schikt en regisseert de historicus zijn toneel - toneel dat hem op wonderlijke wijze zo toegankelijk en tegelijk zo vreemd is. Toegankelijk en vertrouwd, omdat dit zijn eigen voorgeschiedenis is en blijft, vreemd omdat het zo definitief voorbij is.

Leiden, 15 mei 1979 



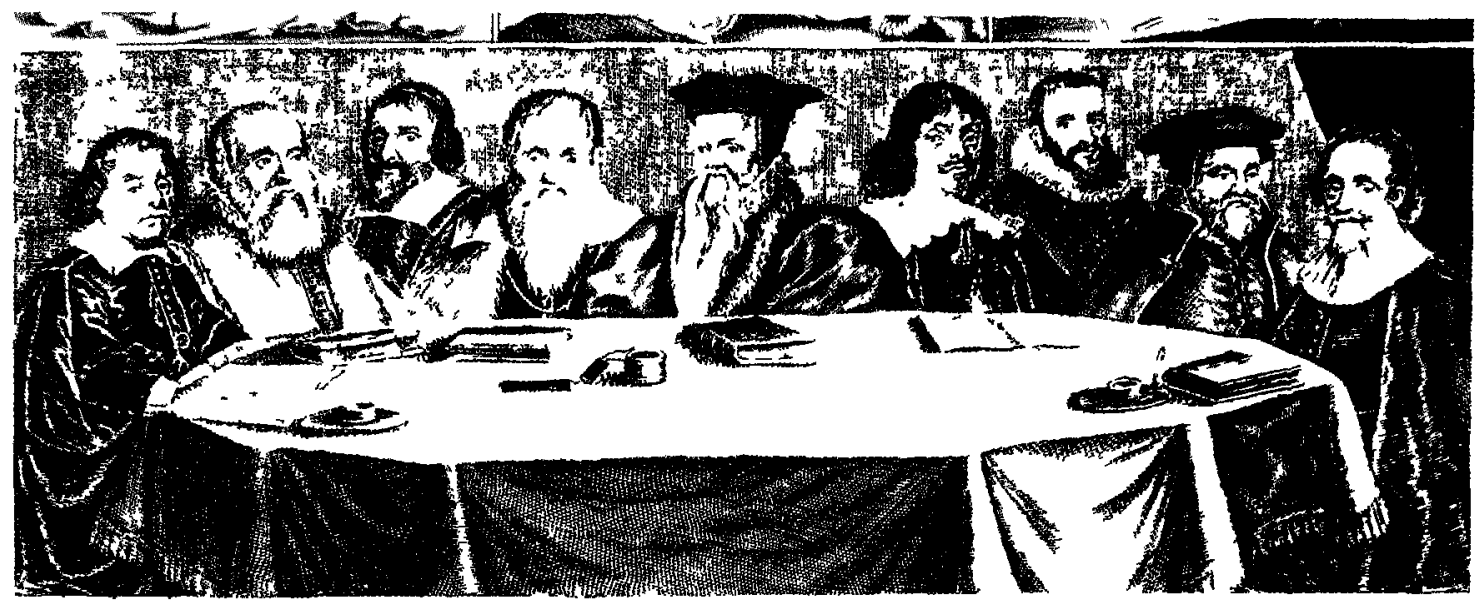

1 Internationale ontmoetıng van vooraanstaande onderzoekers van het Nieuwe Testament uit de 16de en 17de eeuw Van links naar rechts D Heınsıus (Leiden), F Gomarus (Leiden, Gronıngen), F Spanheim (Geneve, Leıden), J Scalıger (Leiden), Th Beza (Geneve), C Salmasius (Leiden), L de Dieu (Leiden), J Camerarius (Tubingen, Leıpzig), H Grotıus (Parıs) Selectiecriterıum was belang voor de filologische en historische verklaring van het Nieuwe Testament Deze maatstaf gaat dogmatische tegen stellıngen te boven calvinist en lutheraan, contra remonstrant en arminiaan zitten aan eén tafel, hoewel Heınsıus en Gomarus niet voor niets zo ver mogelıjk van Camerarıus en Grotius afzitten Opvallend is, dat Scaliger naast de presiderende nestor Beza de ereplaats inneemt 


\section{Dogmatische en filologische interesse in het Nieuwe Testament}

Het eerste universitaire onderwijs in de theologie dat in de Noordelijke Nederlanden is gegeven, heeft bestaan uit lessen over het Nieuwe Testament. In februari 1575 werd de Leidse universiteit ingewijd. Gedurende vijftien weken daarna, van februari tot in mei, gaf de predikant Caspar Coolhaes, tijdelijk aangesteld als professor theologie, openbare lessen waarin hij Paulus' brief aan de Galaten expliceerde. ${ }^{1}$

Dat Coolhaes geen dogmatisch onderwerp, maar een bijbelboek tot stof voor zijn lessen koos, weerspiegelt waarschijnlijk al een weloverwogen opvatting van wat de theologische opleiding moest zijn. Zijn directe opvolger Guillaume Fugueray heeft in juni 1575 deze opvatting in krachtige, deels polemische bewoordingen geformuleerd in een concept-leerplan voor de Leidse universiteit. Voor een juist begrip daarvan moet men zich herinneren, dat ook in katholieke universiteiten de Sacra Pagina werd gedoceerd, maar dat dit onderricht voor een deel niet aan de hand van de Schrift, maar naar aanleiding van de Sententzen van Petrus Lombardus of de Summa van Thomas werd gegeven. Te Leuven bij voorbeeld volgden sinds 1546, toen er twee keizerlijke leerstoelen voor schriftuitlegging en Sententiën waren ingesteld, alle studenten dagelijks minstens een uur exegese en een uur systematische theologie. ${ }^{2}$ Tegen deze praktijk, waarin behalve over de Schrift over een leersysteem werd gedoceerd, neemt Fugueray in zijn ontwerp voor de inrichting van het onderwijs te Leiden met nadruk stelling. Hij meent, dat de opleiding, afgezien van preekoefeningen en disputaties, alleen lessen over het Hebreeuwse Oude Testament en over het Griekse Nieuwe Testament moet omvatten. Hij wijst onderwijs over een theologisch leersysteem uitdrukkelijk af. Minachtend doet hij de auteurs van dogmatische werken die in andere universiteiten worden behandeld (hij doelt waarschijnlijk op Petrus Lombardus en Thomas) af als 'sofisten' en 'folteraars' die hun ondervraging van de Schrift eindeloos voortzetten en hun bronnen kwellen om er de door hen zelf gewenste antwoorden uit te persen. Het voorstel van Fugueray luidt als volgt:

1 Illustrum Hollandiae et Westfrisiae Ordinum Alma Academa Leidensts, Lugdunı Batavorum 1614, p 5 H J Witkam, Immatnculatze en recensıe in de Letdse Universttet, Leiden 1975 1976, II B, p 189

${ }^{2} \mathrm{E} J \mathrm{M}$ van $\mathrm{E}_{\mathrm{l}} \mathrm{l}$, 'De Theologische Facultelt te Leuven in de $\mathrm{xv}^{\mathrm{e}}$ en $\mathrm{xvl}^{\mathrm{e}}$ eeuw organısatıe en opleıding', in id , Facultas $S$ Theologiae Lovaneensts 1432 - 1797, Leuven 1977

(Bıbl Ephemerıdum Theologicarum Lovaniensıum 45), pp 69 - 153, zie p 131 
'Opdat men hier (in Leiden) theologie kan leren, worden er geen folteraars of sofisten, die aan de waarheid niet gewend zijn, behandeld; maar die twee hemelse en goddelijke zonnen, de een van het Oude, de andere van het Nieuwe Testament, worden er uit de Hebreeuwse en Griekse tekst geïnterpreteerd.'

'Hic, ut theologiam discere queat, non quaestionarii aut sophistae veritatis insolentes proponuntur, sed soles illi duo caelestes ac divini, alter Testamenti veteris Hebraice alter novi Graece exponuntur' ${ }^{3}$

Beperking van het theologisch hoger onderwijs tot explicatie van de Schrift was in 1575 reeds een hechte protestantse traditie. Aan de door Zwingli gereorganiseerde theologische opleiding te Zürich was al in 1525 de gebruikelijke scholastieke dogmatiek afgeschaft en de uitlegging van Oude en Nieuwe Testament tot enig object van het onderwijs gemaakt. ${ }^{4}$ Sinds 1531 kende Bazel in de theologische faculteit maar twee ordinarii: een oud- en een nieuwtestamenticus: vulgata, Glossa en Petrus Lombardus hadden er afgedaan. ${ }^{5} \mathrm{Bij}$ de reformatie van de universiteit van Tübingen in januari 1535 werd in de theologische faculteit alleen nog in onderwijs over Oude en Nieuwe Testament voorzien. ${ }^{6}$ Ook te Wittenberg, waar in 1519 nog over Petrus Lombardus werd gedoceerd, ${ }^{7}$ vormde sedert 1536 de interpretatie van de heilige Schrift nog vrijwel het enige onderwerp der theologische lessen. ${ }^{8}$ De van 1547 daterende Leges van de Academie van Lausanne bepaalden dat de theologische hoogleraar zijn gehele onderwijs moest inrichten als uitlegging van Oude en Nieuwe Testament; voor zover hij bij zijn voortgaande behandeling van de bijbeltekst gegevens ontmoette die met de locı communes verband hielden, moest hij die in de lessen exegese behandelen. ${ }^{9}$ In de Geneefse Leges academıae van 1559 omschreef Calvijn de taak van de twee professores publıcı in de theologie in niet meer dan drie woorden: 'Sacros libros interpretantor'. ${ }^{10}$ Ook in de theologische faculteit van de in 1556 calvinistisch geworden universiteit te Heidelberg werd in 1569 alleen over Oude en Nieuwe Testament gedoceerd. ${ }^{11}$ Deze voorbeelden mogen volstaan ter aanduiding van de traditie waaraan Leiden

3 P C Molhuysen, Bronnen tot de geschiedents der Lezdsche Untversitett I, 's-Gravenhage 1913, p $41^{*}$

$4 \mathrm{H}$ H Kuyper, De oplezding tot den dienst des Woords by de gereformeerden, 's-Gravenhage 1891, pp $114-121$

5 E Bonjour, Die Untversitat Basel, Basel 1960, pp $207-208$

6 Urkunden zur Geschichte der Universitat Tubingen aus den Jahren 1476 bis 1550 (ed R Roth), Tubingen 1877, pp $183-184$

7 K Aland, 'Die theologische Fakultat Wittenberg wahrend des 16 Jahrhunderts', in 450 Jahre Martin-Luther-Unversitat Halle-Wittenberg I, Wittenberg 1952, pp 155 - 237, zie p 167

8 W Friedensburg, Geschichte der Untversitat Wittenberg, Halle 1917, p 181

9 L Junod en H Meylan, L'Académıe de Lausanne au XVI siècle, Lausanne 1947, p 31

${ }^{10} \mathrm{Ch}$ Borgeaud, Histotre de l'Université de Genève L'Académıe de Calvın 1559 - 1798, Genève 1900, p 632

11 E Winkelmann, Urkundenbuch der Universitaet Hezdelberg I, Heıdelberg 1886, p 308 - 309 
zich in 1575 aansloot. Want al is het leerplan van Fugueray nooit officieel aanvaard, met zijn idee dat in de theologische faculteit alleen over de Schrift en niet over de dogmatiek gedoceerd moest worden is de praktijk althans de eerste twintig jaar in overeenstemming geweest. De series lectionum vermelden bij voorbeeld lessen van A. Saravia over Hebreeën (1587), van L. Trelcatius sr. over Matthaeus (1587) en I Corinthiërs (1592) en van F. Gomarus over Romeinen (1595). ${ }^{12}$

$\mathrm{Nu}$ moet men zich wel zeer hoeden voor de gedachte, dat met de nieuwe aanpak van het theologisch onderwijs de dogmatiek zou zijn uitgebannen en een exegese haar intree zou hebben gedaan die de bijbelse geschriften beschouwde als antieke godsdienstige documenten die zich uitsluitend richten tot een in ruimte en tijd beperkt publiek in het verleden. Het tegendeel is het geval. Niet alleen keerden te Leiden, zoals in alle protestantse universiteiten, na verloop van enige tijd speciale lessen over de dogmatiek, de loci communes, in het onderwijsprogramma terug; te Leiden begon Trelcatius sr. er mee in 1595. Maar vooral werd de dogmatiek, toen die tijdelijk niet in aparte lessen onderwezen werd, eenvoudig ondergebracht in de lessen bijbelexegese: en zo is het, ook toen de loci communes weer apart gedoceerd werden, eeuwen lang gebleven, in de Leidse universiteit zo goed als in die van Franeker (gesticht in 1585), Groningen (1614), Utrecht (1636) en Harderwijk (1648). En niet veel anders was het bij de theologische professoren van het Remonstrants Seminarie te Amsterdam (gesticht 1634).

Van de exegeet werd in de 16de en 17 de eeuw nu eenmaal verwacht, dat hij de Schrift zó uitlegde, dat (naar een woord van Calvijn ${ }^{13}$ ) 'de gezonde staat der leerstellingen gehandhaafd werd', ut dogmatum sanitas retineatur. In die visie is van de exegese de dogmatiek vooronderstelling en doel. De vraagstelling van de exegeet wordt beheerst door dogmatische interesse. In de praktijk betekende dit, dat de exegeet bij het behandelen van een bijbelboek gedurig dogmatische uitweidingen maakte, waarin hij uit de bijbeltekst actueel theologische zienswijzen distilleerde. ${ }^{14}$ Het procédé is reeds beschreven door Joh. a Lasco. Deze vertelt, dat hij te Londen in 1552 het Johannes-evangelie exegetiseerde en daarbij de doop van Johannes aangreep om uitvoerig over de sacramenten te handelen. ${ }^{15}$ Te Lausanne schreven de Leges academiae, als boven vermeld, de behandeling van loci communes in de lessen exegese zonder meer voor. Deze in gereformeerd milieu algemeen verbreide methode nu weerspiegelt zich duidelijk in de bijbelcommentaren van de 16 de en 17 de-eeuwse theologen. Hierin worden steeds aan korte passages van een bijbelboek dogmatische uiteenzettingen en conclusies vastgeknoopt. Zulke commentaren zijn er o.m. van F. Junius (Leiden 1592 - 1602), F. Gomarus (Leiden 1594-1611 en Groningen 1618 - 1641), J. Coccejus (Franeker 1636 - 1650 en Leiden

12 Molhuysen, Bronnen, I, pp. 157*, 192* 362*.

13 Commentaar op Eph. 4: 11.

14 P. Fraenkel, De l'Ecriture à la dispute (Cahiers de la Revue de théologie et de philosophie 1), Lausanne 1977, pp. 7 en 13.

${ }^{15}$ Kuyper, Opleiding, p. 296. 
1650 - 1669) en Jac. Alting (Groningen 1667 - 1679, professor oosterse talen vanaf 1643). ${ }^{16}$ De commentaren van de remonstrantse hoogleraren J. Arminius en Ph. van Limborch zijn niet minder dogmatisch bepaald dan die der rechtzinnigen. In Coccejus' commentaren vindt men wel her en der de vruchten van zijn belezenheid in de rabbijnse literatuur, maar dat neemt in het geheel niet weg, dat ook hier de exegese dient om met beroep op de bijbel een dogmatisch systeem te legitimeren: op de meest ongeschikte plaatsen van het Nieuwe Testament ziet Coccejus kans, aanwijzingen te vinden van de onderscheiden verbonden Gods die het stramien van zijn eigen dogmatisch leersysteem vormen.

Het instrument waarmee de 17 de-eeuwse theologen in hun commentaren de Schrift ommuntten tot de systematische theologie die zij aanhingen wordt gevormd door een gesofisticeerd systeem van scholastieke distincties waarmee de bijbeltekst werd ondervraagd en op de gewenste manier tot spreken gebracht. Jac. Alting bij voorbeeld onderzoekt van de in Hebr. 6:17 genoemde eed die God bij zichzelf zwoer om Abraham van zijn zegen te verzekeren achtereenvolgens de res ipsa, de forma rei, de finis, de causa efficiens, de causa impulsiva, de materia circa quam seu objectum en het subjectum. ${ }^{17}$ Met deze als heuristisch apparaat dienende onderscheidingen kan Alting o.m., hoewel in Hebr. zelfs de geringste bedenking omtrent de toelaatbaarheid van eden afwezig is, de vraag aansnijden, of eden geoorloofd zijn. Daarentegen laat hij geheel buiten beschouwing, dat de reden waarom God bij zichzelf zwoer ook door Philo opgegeven wordt, hetgeen enig licht werpt op de relatie van Hebr. 6:13 tot de Hellenistisch-joodse exegetische traditie, althans bij Gen. 22:16. Grotius had de parallellen gesignaleerd, maar dat hierdoor zoiets als een literair milieu of een traditie was aangeduid, stond buiten de belangstellingssfeer van Alting.

Dat bij theologen de belangstelling voor dogmatische kwesties ook wanneer zij exegese bedreven zo intens was en de interesse voor wat de bijbelse geschriften in hun ontstaanstijd voor de oorspronkelijke belanghebbenden hadden betekend zo gering, hangt samen met wijd verbreide aprioristische opvattingen omtrent de plaats van de bijbel in het geheel van de theologie en van de theologie in de christelijke samenleving. Op beide moge hier kort worden ingegaan.

Ter illustratie van de visie die in de 17 de eeuw menig theoloog in Noord-Nederland op de bijbel had diene hier een passage uit het 'Overzicht van de gezuiverde theologie', de Synopsis purioris theologiae, door de vier hoogleraren van de Leidse theologische faculteit gezamenlijk in 1625 in het licht gegeven en representatief voor de in brede kring aanvaarde gereformeerde leer van het tweede kwart der 17de eeuw. Men schrikke niet van het Aristotelisch jargon: het is voor de calvinistische neoscholastiek van de tijd heel gewoon.

16 Men vindt de nieuwtestamentische commentaren van deze theologen gemakkelijk in de uitgaven van hun verzamelde werken.

17 Jac. Alting, Praelectiones in Epistolam ad Hebraeos, in: Opera omnia IV, Amsterdam 1686, zie ad Hebr. 6:16 - 20. 
'Materia scriptionis, est sermo, quo res, mens sententiaque divina, puta de natura Dei, ejusque gratuita et benevola voluntate, enunciatur; estque hic sermo, seu sermonis genus et character plane divinus, 1 Cor. 2,13. Forma autem est in veritatis et mentis divinae, sermone prolatae, divina expressione, scripto facta. Finis denique, est omnium, et praesentium, maxime absentium, de rebus divinis institutio, 2 Cor. 10, $10-11$; Joh. 20, 31 ; Rom. 15,4, quae, prout scriptio vel ad pauciores, vel plures primo dirigebatur et spectabat, ita vel particularior, vel communior fuit'. ${ }^{18}$

'De stof (materia) van hetgeen er geschreven staat is de taal waarin de realiteit, de bedoeling en het oordeel van God, bv. over Gods wezen en zijn onbaatzuchtige en welwillende wil, tot uitdrukking wordt gebracht en deze taal, of de aard en het wezen van deze taal, is volstrekt goddelijk (1 Cor. 2,13). De vorm (forma) echter bestaat in de goddelijke, in schrift neergelegde weergave van de goddelijke realiteit en bedoeling, in taal meegedeeld. Het doel (finis) tenslotte is de onderrichting van alle mensen, zowel van degenen tot wie het geschrevene zich oorspronkelijk richtte, als vooral van hen die er in ruimte en tijd ver van afstaan (2 Cor. 10, 10 - 11; Joh. 20, 31; Rom. 15,4). En dit onderricht was, naar gelang het geschrevene gericht was tot of betrekking had op minder dan wel meer mensen, meer bijzonder of meer algemeen van aard'.

In deze thesis van de hoogleraar Antonius Thysius wordt erkend, dat de bijbel iets geschrevens, een scriptio of scriptum, is, bestaande uit taal, sermo. Erkend wordt ook, dat er oudtijds een publiek geweest is, contemporain met het ontstaan van de bijbelboeken, voor wie het geschrevene bestemd was: de praesentes. In een volgende, hier niet geciteerde thesis wordt dan nog gezegd, dat de sermo, voor zover het het Nieuwe Testament betreft, het Grieks is, omdat dat destijds de meest verbreide taal was in Oost en West. Dan volgt nog een niet eens zo slechte typering van de stijl van dit Grieks van het Nieuwe Testament als deels vulgaris, deels Hebraeo-graecus en als de stijl gebruikt door de joodse Hellenisten. Maar daarmee is de literairhistorische interesse van de auteurs van de Synopsis uitgeput. Voor deze theologen gaat het in de bijbel niet om het scriptum, om de sermo, om de betekenis ervan voor de praesentes in een ver verleden. Voor hen staat tegenover de sermo de goddelijke realiteit, de res divina; en de bijbelse geschriften zijn, behalve voor de oorspronkelijke geadresseerden en betrokkenen in de oudheid, bestemd voor alle mensen, vooral voor hen die in de tijd ver van het ontstaan van die geschriften verwijderd zijn: voor omnes, maxime absentes.

Het onderscheid tussen sermo en res en dat tussen praesentes en absentes stelt de exegeet in staat, het bestaan van de linguistische, literaire en godsdiensthistorische aspecten van bijbelse geschriften te erkennen en ze

18 J. Polyander, A. Rivetus, A. Walaeus, A. Thysius, Synopsis purioris theologiae (ed. H. Bavinck), Lugduni Batavorum $1881^{6}$, p. 18 (Disputatio III, thesis IX). 
tegelijk te veronachtzamen. De theologisch gemotiveerde exegeet richt zijn blik over de tijdgebonden eigenschappen van de bijbel, al met al niet meer dan stof (materia), héén op het wezenlijke van de Schrift, de res, dat is de goddelijke werkelijkheid, de veritas divina, die eeuwig geldig is.

De juist geschetste opvattingen behoeven hier niet gekritiseerd te worden. Wat hier vooral de aandacht verdient, is dat de gereformeerde orthodoxie met behulp van de Aristotelische categorieën stof en vorm ( = het wezenlijke) onderscheid maakte tussen enerzijds het tijdgebondene en anderzijds het duurzaam geldige in de bijbel. Dit maakte het mogelijk, dat theologen hun aandacht onevenredig verdeelden over de twee onderscheiden grootheden. Voor de bijbelse geschriften als antieke literair- en godsdiensthistorische documenten hadden zij relatief zeer weinig interesse. Hun belangstelling gold bijna uitsluitend de Schrift als bron van een absoluut geldige leer. Voor hen was de bijbel de theologiae causa instrumentalis (Synopsis I, 14), het principium omnis veritatis (III, 18).

Eén van de oorzaken waardoor de theologische exegeten overwegend dogmatisch geïnteresseerd waren, was gelegen in de rol die men gewoonlijk de gereformeerde theoloog toedacht in de samenleving. Gereformeerde theologen waren geen misdienaren, maar predikanten, die geacht werden in staat te zijn de nieuwe religie, één van de dingen waarom de Nederlanden tot 1648 in oorlog waren, effectief te verdedigen tegen roomsen, anabaptisten, joden, arminianen, socinianen en tal van andere heterodoxe belagers van de waarheid. Voor deze polemiek werden de theologische studenten constant intensief getraind in disputaties, dat nog altijd zo vitale erfdeel van de middeleeuwse universiteit. Daar de polemiek steeds dogmatische geschilpunten betrof, moest ook de ammunitie waarmee in de talrijke, soms heftige disputaties werd gestreden, van dogmatische aard zijn. Maar tegelijk mocht alleen de Schrift (sola scriptura) argumenten leveren. Het was daardoor de onontwijkbare taak van de exegeten, vanuit de Schrift het materiaal voor de dogmatische polemiek te leveren. De 17de-eeuwse theologen gaan in hun bijbelcommentaren trouwens ook zonder didactische noodzaak gemakkelijk tot polemiek over actuele en zelfs antieke dogmatische geschillen over. Zo droeg de opvatting van het predikantschap en van de taak van de gereformeerde theoloog in het algemeen ertoe bij, dat de exegese aan de dogmatiek onderhorig bleef.

Natuurlijk was al evenmin bevorderlijk, dat in de 16 de en 17 de eeuw de theologische hoogleraren geen specifieke leeropdrachten hadden, maar zonder nader onderscheid voor het onderwijs in de theologie werden aangesteld. De zeldzame keren dat aan theologische hoogleraren meer in het bijzonder de uitlegging van het Nieuwe Testament werd opgedragen brachten geen enkele verbetering. In 1611 werd in Leiden Joh. Polyander benoemd; van hem werd inzonderheid de interpretatie van het Nieuwe Testament verwacht. ${ }^{19}$ Gedurende 35 jaar heeft hij de universiteit met

19 J. Polyander, in: Orationes inaugurales a SS. Theologiae professoribus ... habitae, Lugduni Batavorum 1620, fol. *3r.; Ioa. Meursius ed., Athenae Batavae, Lugduni Batavorum 1625, p. 329 . 
toewijding gediend en zich als docent en op bestuurlijk, organisatorisch, representatief en ook pastoraal vlak verdienstelijk gemaakt. Maar het vak Nieuwe Testament heeft hij geen bijzondere impulsen gegeven. Zijn enige als een 'verclaringhe' van een gedeelte Nieuwe Testament aangediende werk is zijn Grondt onser salucheyt ${ }^{20}$ Hierin knoopt hij evenwel aan de verzen Eph. 1:3-7 en 2:1 - 10 een reeks dogmatische, ten dele schoolse en stichtende tractaten vast waarin hij, overigens op een heel sympathieke wijze, de infralapsarische praedestinatie- en verlossingsleer van de Dordtse orthodoxie uiteenzet. ${ }^{21}$

In het jaar van Polyanders dood, 1646, werd ook te Groningen een theologisch hoogleraar benoemd aan wie speciaal de 'professio Novi Testamenti' werd toevertrouwd: de humane Abdias Widmar. Hij bekleedde dit ambt 22 jaar, tot zijn dood in 1668, maar was te bescheiden om te publiceren. In zijn openbare lessen expliceerde hij inderdaad nieuwtestamentische passages, maar met name de in de dogmatiek omstreden bewijsplaatsen. Deze verdedigde hij tegen valse interpretaties van vooral socinianen. Ook exploreerde hij nieuwtestamentische tekstgedeelten op hun nut voor de kerkelijke praktijk. ${ }^{22}$ De literairhistorische bestudering van het Nieuwe Testament heeft hij even weinig als Polyander bevorderd. Hetzelfde moet worden gezegd van de theologische hoogleraar Carolus de Maets aan wie te Utrecht de uitlegging van het Nieuwe Testament werd toebedeeld (1640 - 1651). ${ }^{23}$ Hij moge zich in zijn lessen hierop hebben toegelegd, zijn publicaties zijn uitsluitend van dogmatische en ethische inhoud en van Voetiaanse signatuur.

Toch zijn het vooral Noordnederlanders geweest die in de 17 de eeuw aan de ondogmatische bestudering van het Nieuwe Testament een zelfstandige plaats naast de leerstellige en polemische theologie hebben weten te geven. In oorsprong heeft deze ontwikkeling, anders dan soms betoogd wordt, ${ }^{24}$ weinig of niets te maken met de opkomst van een inductieve wetenschapsbeoefening en van het rationalisme. Weliswaar

20 Grondt onser salucheyt Dat us, De leere onser Verkiesinghe ende Verlossinghe van den doot der Sonden/door Jesum Christum Wt eenighe versen des eersten ende tweeden Capittels des Sentbriefs Paull tot den Ephesien, voorghestelt, Leyden 1630 Ik betuig mijn oprechte dank aan dr A J Lamping, Leiden, die mıjn aandacht op de Grondt wilde vestigen, en aan ds A J de Jong, Leiden, die mij zijn exemplaar van dit zeldzame boek ter leen gaf

21 Interessant is wat Polyander op p 326 signaleert, nl dat dienaren des Woords 'het Evangelıum Chrıstı nu oock gaen vercondighen in Amerca, het vierde ende laetste deel der werelt, tot het welcke nu oock onlancx ghecomen is het licht des Heeren' Met recht mag men hierom met Paulus uitroepen, aldus Polyander 'Is God alleen der joden God? Niet ook der heidenen? Ja, ook der heidenen' (Rom 3 29)

22 Effigzes et vitae professorum academıae Groningae $\mathcal{B}$ Omlandıae, Gronıngae 1654, p 194 Voor Widmars lessen $\mathrm{P}$ Dibon, 'Le schema lectıonum publicarum de 1647 Premıère serıes lectionum imprimée de l'Unıversité de Groningue', Quaerendo 7 (1977), pp 58 - 65, zie 60

${ }^{23} \mathrm{C}$ Sepp, Het godgeleerd onderwiss in Nederland gedurende de 16e en 17 e eeuze, II, Leiden 1874, pp 163 - 164, A C Duker, Gisbertus Voetius, III, Leiden 1914, pp 2 - 3, beider bron C Burman, Trajectum eruditum, Traj ad Rh $1750^{2}$, pp 203vv, J A Cramer, De Theologesche Facultett te Utrecht ten tyde van Voetzus, Utrecht 1932, pp 10, 16, G W Kernkamp, De Utrechtse Academe 1636 - 1815, Utrecht 1936, p 238

${ }^{24}$ B v door R M Grant, die in zijn The Bible in the Church A Short History of Interpretalion, 
hebben de veranderingen die een Copernicus, een Descartes en een Spinoza in het Europese denken teweeg gebracht hebben, bijgedragen tot de ondergang van oude ideologieën, ook de gereformeerde, en daarmee indirect ook tot het afsterven van de door de dogmatiek beheerste exegese. Maar naast dit in de 19de eeuw vrijwel ondergegane type exegese is in de 16 de en 17 de eeuw reeds een ander soort bijbelwetenschap tot ontplooiing gekomen, geinspireerd niet door het rationalisme. maar door de trilingue filologie die een vrucht van het humanisme is. Filologen konden zich nu eenmaal makkelijker dan de theologen vrij maken van de plicht, de bijbel te transponeren in termen van een $16 \mathrm{de}$ - of 17 de-eeuwse doctrine. Daardoor waren zij het, die zich konden concentreren op het onderzoek naar wat de geschriften van het Nieuwe Testament hadden betekend in de historische context van hun ontstaanstijd. Deze meer filologische bestudering van de bijbel vindt men evenzeer in rechtzinnig als in remonstrants milieu: beide kampen hadden, naast dogmatische exegeten, beoefenaars van een historisch-filologische bijbelinterpretatie. Op dit punt bestaat er tussen 'preciezen' en 'rekkelijken' geen wezenlijk verschil. Wèl waren de meeste vertegenwoordigers van deze nieuwe bijbelwetenschap in de 17de eeuw nog werkzaam buiten de theologische faculteiten: zij waren doorgaans verbonden aan de faculteiten der artes, ook wel aan het Waals College en het Remonstrants Seminarie. Maar in de 17de eeuw hebben zij buiten de theologische faculteiten een ontwikkeling ingezet, die in de $19 \mathrm{de}$ eeuw daarbinnen kon worden voortgezet.

New York 1948, tussen Reformatie en 19de eeuw slechts één hoofdstuk zet onder de titel 'The Rise of Rationalism', waarın na Erasmus en Colet ter sprake komen zulke rationalisten als Matthew Hamond, Thomas Hobbes, Spınoza, Zwicker en L Meyer, maar niet Grotıus, Heinsıus, Drusıus, De Dieu of zelfs Clericus en Wettstein K Scholder, Ursprunge und Probleme der Bibelkrtık ım 17 Jahrhundert, Munchen 1966, interesseert zich niet zozeer voor de geschiedenıs der exegese en bujbelwetenschap, als voor het proces van de ondergang van het vertrouwen in het gezag der Schrift, daardoor spelen filosofen voor hem een grotere rol dan exegeten Een (te) lichte correctıe hierop vormt V P Furnish, 'The Historical Critıcism of the N T A Survey of Origıns', Bulletin of the John Rylands University Ltbrary 56 (1974), pp $336-370$ 



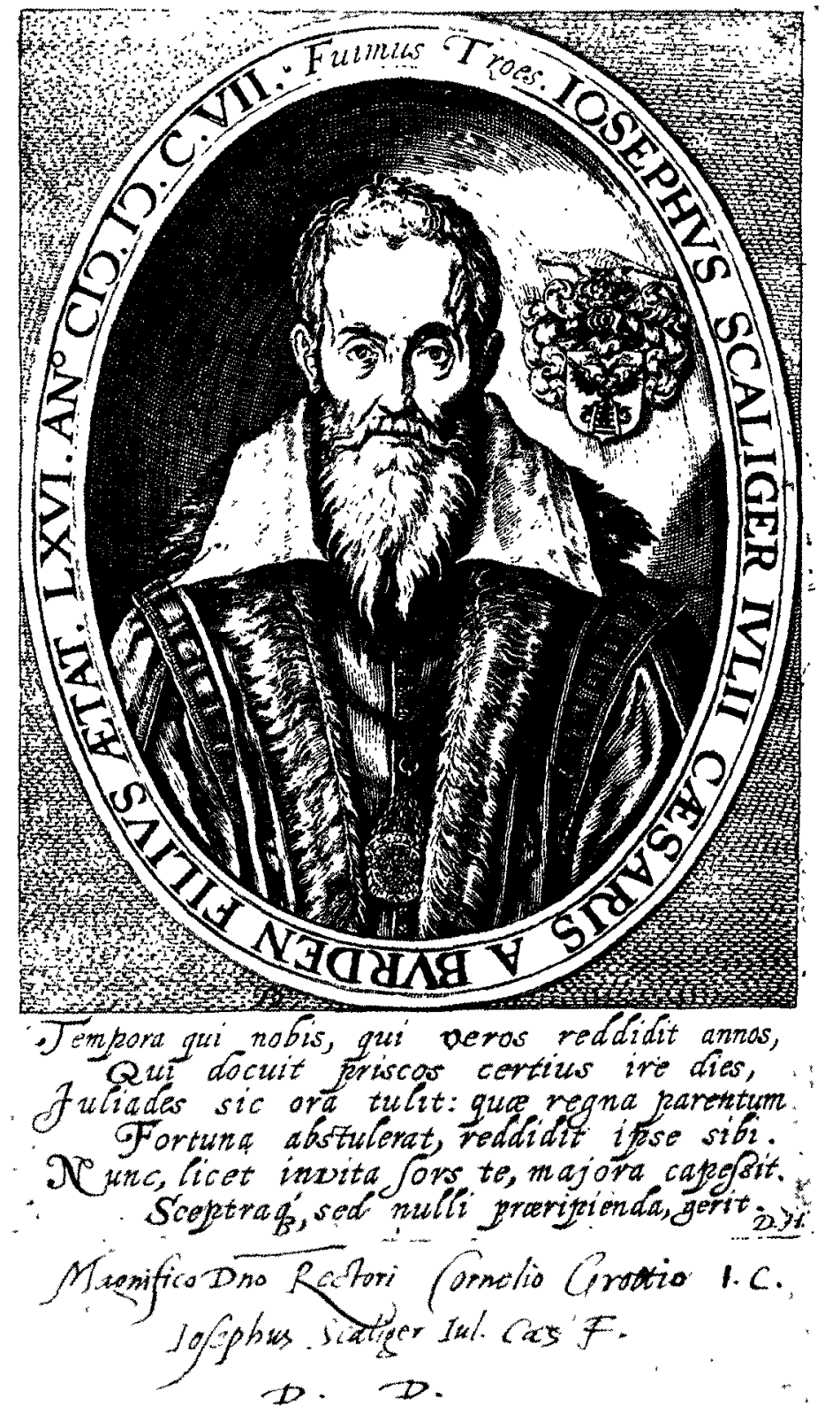

2. Josephus Scaliger, 1607. 


\section{Tekstkritiek en edities}

van oude vertalingen

Weinig vooruitgang werd voorlopig gemaakt op het terrein van de tekstkritiek. De Griekse tekst van het Nieuwe Testament nam in de gedrukte uitgaven van de 16 de eeuw, en met name in de negen onderling weinig verschillende edities die de Geneefse kerkleider Th. Beza van 1565 tot 1604 uitgaf, een min of meer vaste vorm aan, waar het calvinistische NoordNederland zich met een onbekommerd vertrouwen bij neerlegde. Door de opkomende leer van de verbale inspiratie der Schrift werd dit vertrouwen nog versterkt. Tegen de op dit gebied algemeen heersende zorgeloosheid steekt evenwel scherp het oordeel af van Joseph Scaliger, de zeldzaam schrandere en geleerde chronoloog en criticus die van 1593 tot zijn dood in 1609 in een erefunctie verbonden was aan de Leidse universiteit. Niet in het openbaar - dat was hem te gevaarlijk - maar in een besloten kring van studenten, verklaarde Scaliger, dat de in zijn tijd bereikbare manuscripten van het Nieuwe Testament 'zeer corrupt' waren en dat men een oudere, betere tekst zou kunnen winnen uit de bijbelcitaten bij kerkvaders. ${ }^{25}$ Scaligers negatieve oordeel over de beschikbare handschriften zal, behalve op de in zijn bezit zijnde collaties van enige nieuwtestamentische tekstgetuigen, ${ }^{26}$ vooral gebaseerd geweest zijn op zijn ervaring, dat de evangeliën hem als chronoloog en historicus her en der voor onoverkomelijke harmonisatieproblemen stelden. Hij weet deze aporieën aan christelijke interpolaties in oude evangeliehandschriften. ${ }^{27}$ Maar dit neemt niet weg, dat zijn pleidooi voor een tekst uit patristische citaten een juist inzicht in de tekstgeschiedenis en een heilzame onafhankelijkheid tegenover de gangbare tekst verraadt. Het was vermoedelijk onder Scaligers invloed, dat de Leidse hoogleraar Hebreeuws W. Coddaeus $\left(1601\right.$ - 1621) ${ }^{28}$ inderdaad werkte aan een verzameling van 'Nieuwtestamentische citaten bij patristische en andere Griekse auteurs, voor zover deze van de gedrukte teksten der bekende handschriften en hun varianten afwijken, of reeds

25 Scalgerana, etc (ed P des Malzeaux), Amsterdam 1740, p 589

26 Deze collaties stelde hij ter beschikkıng van zijn leerling Ant Thysius sr, wiens afschrift bekend was aan J J Wettstein, Novum Testamentum Graecum I, Amsterdam 1751, p 47, en onlangs door de Leidse U B is verworven (1978) liber annotatus 765 A 9

27 Scaligerana, pp 304, $398-399$

28 Zie over hem J C H Lebram, 'Hebraische Studien an der Universitat Leiden in den Jahren 1575 - 1619', Ned Archıef voor Kerkgeschiedenis 56 (1975), pp 317 - 357, vooral $351-354$ 
vastgestelde varianten bevestigen en steunen' ${ }^{29}$ Het werk is nooit gepubliceerd.

De onafhankelijke houding van Scaliger tegenover de gangbare tekst blijkt eveneens uit de vrijmoedigheid waarmee hij hem met conjecturen trachtte te verbeteren. Eén hiervan bestond uit niet minder dan een door Scaliger zelf uitgedacht Grieks werkwoord, dat nog nergens in de hele toenmaals bekende Griekse literatuur voorkwam, maar dat later inderdaad op de bewuste plaats, Philip. 2:30, in oude handschriften bleek te staan: paraboleusamenos, 'die (zijn leven) op het spel gezet heeft'.${ }^{30}$ Momenteel wordt deze lezing in alle kritische uitgaven gedrukt. Deze conjectuur is naar mijn weten de enige die, zij het ook dankzij bevestiging door gezaghebbende handschriften, deel is geworden van de moderne kritische tekst van het Nieuwe Testament. Indien niet vergeten was, dat de lezing paraboleusamenos in 1600 werd voorgesteld als conjectuur, dan had deze ene conjectuur een eeuwen lange discussie over de vraag of conjecturen in het Nieuwe Testament toelaatbaar zijn, overbodig kunnen maken.

Intussen drukten de officiële universiteitsdrukkers te Leiden, Raphelengius en de Elzeviers, van 1591 tot 1641 zo'n acht edities van het Griekse Nieuwe Testament, waarvan de tekst in hoofdzaak ofwel via de Antwerpse Polyglot terugging op de Complutensische Polyglot, ofwel via Beza en Robert Estienne op Erasmus. ${ }^{31}$ In beide gevallen is het resultaat een late, inferieure, Byzantijnse recensie. Hoe onbeholpen de tekst van zulke edities werd vastgesteld, kan worden geillustreerd aan het geval van de tweede Elzeviersuitgave, die verscheen in 1633. De Leidse hoogleraar Grieks, Jeremias Hoelzlin, nam een exemplaar van de voorafgaande Elzeviersdruk en collationeerde die tegen een exemplaar.van een editie gemaakt door Henri Estienne jr., Genève $1576 .{ }^{32}$ Hij wijzigde de Elzevierstekst op 13 plaatsen in overeenstemming met de tekst van Henri Estienne, op nog 3 plaatsen overeenkomstig een editie van Robert Estienne van 1550 of 1551 en dit was vrijwel alle tekstkritische arbeid besteed aan de nieuwe uitgaaf. Het resultaat werd door Daniël Heinsius, wetenschappelijk adviseur van de Elzeviers, in het namens de drukkers geschreven voorwoord aangeprezen als 'de tekst, zoals die nu door iedereen wordt aanvaard, vrij van elke opzettelijke of door een fout veroorzaakte afwijking (nl. ten opzichte van de oorspronkelijke tekst)'. Uit deze passage stamt de term textus receptus.

Daniël Heinsius, graecus en hoogleraar geschiedenis, handelde uitvoerig over de tekst van het Nieuwe Testament in de prolegomena tot zijn eigen Exercitationes sacrae van 1639. Zijn uiteenzetting is een pleidooi voor de grootst mogelijke terughoudendheid in de tekstkritiek. Hij erkent dat van

${ }^{29}$ Meursius, Athenae Batavae, p. 284. Het werk wordt nog niet aangekondigd in het boven in n. 1 geciteerde Alma Academia Leidensis van 1614.

$30 \mathrm{Vgl}$. 'Eine Konjektur Joseph Scaligers zu Philipper II 30', Novum Testamentum 17 (1975), pp. 297 - 302. Ook Hand. 16:12 wordt nu vaak met een conjectuur gedrukt, zie p. 25. 31 Ed. Reuss, Bibliotheca Novi Testamenti Graeci, Brunsvigae 1872.

32 Vgl. "Jeremias Hoelzlin: Editor of the "Textus Receptus" printed by the Elzeviers, Leiden, 1633', in: T. Baarda e.a. (edd.), Miscellanea Neotestamentica I, Leiden 1978. (Supplements to Novum Testamentum 47), pp. 105 - 128. 
oudsher in de handschriften lezingen voorkomen die afwijken van die in de gangbare gedrukte tekst, maar deze varianten doen niet af aan wat men moet geloven, noch leren ze wat men niet moet geloven. De onverwachte tekstvorm van nieuwtestamentische passages in citaten bij kerkvaders schrijft Heinsius, geheel anders dan Scaliger, toe aan een vrije manier van citeren. Daarom moet er z.i. tegen gewaakt worden, dat wat inmiddels als tekst aanvaard is lichtvaardig veranderd wordt: 'caveatur, ne quod iam receptum, facile immutetur'. ${ }^{33}$ Alleen zó wordt voorkomen, dat Gods woord verandert in het woord van een editor. Vergelijking van handschriften en signalering en beoordeling van varianten acht Heinsius toegestaan, maar lezingen van één of enkele getuigen mogen niet die van de algemeen aanvaarde tekst vervangen. Verder dan de marge mogen varianten niet komen. Conjecturen mogen worden voorgesteld, mits ze niet meer dan één of twee letters van de overgeleverde tekst wijzigen. Ze mogen echter niet in de tekst worden opgenomen, omdat dit tot het ontstaan van een 'persoonlijke recensie', een 'propria editio' zou leiden. Eigenlijk vormt de tekstkritiek van het Nieuwe Testament in Heinsius' ogen een reeds afgesloten hoofdstuk in de geschiedenis der wetenschap: 'Het is nauwelijks te zeggen of te bevroeden, hoeveel menselijke inspanning er besteed is aan het herstel van de ware, oorspronkelijke tekst, vooral door mensen van onze huidige tijd, waarin de letteren en talen herboren zijn'. ${ }^{34}$ 'De beste en oudste codices zijn thans allang gecollationeerd; welnu, daaronder is er nauwelijks één zo vrij van fouten, dat die tegen alle overige op alle onzekere plaatsen gevolgd zou moeten worden'. ${ }^{35}$

Bij alle belezenheid en kennis waarop Heinsius kon roemen, was zijn standpunt inzake de tekstkritiek van het Nieuwe Testament merkwaardig conservatief. Maar het was in zijn tijd de gebruikelijke zienswijze, en het kon ook erger. Zijn theologische collega Andreas Rivetus (Leiden, 1620 1632) bij voorbeeld schreef: 'De tekst van het Nieuwe Testament is vlekkeloos bewaard gebleven. Weliswaar komen er her en der varianten voor, maar die zijn als zodanig ook nauwkeurig gemarkeerd en de verstandige en aandachtige lezer hoeft er zich, wanneer hij ze vergelijkt met hetgeen in de tekst voorafgaat en volgt, niet door te laten ophouden, vooral niet in passages die op de regel des geloofs betrekking hebben' ${ }^{36}$ Zo'n mededeling is niet geheel boven alle verdenking van onwaarachtigheid verheven, want hoe kan iemand beweren dat de varianten in kwestie 'religiose etiam notatae' zijn; maar tekenender is de nonchalance tegenover het door de varianten opgeroepen tekstkritisch probleem die uit Rivetus' woorden blijkt. Het vertrouwen in de gangbare tekst, door godsdienstige scrupules gevoed, was nog onvoldoende op de proef gesteld. Er moesten blijkbaar eerst nog veel meer varianten verzameld en gepubliceerd worden, alvorens het idee

33 D. Heinsius, Exercitationes sacrae, Lugduni Batavorum 1639, p. (6).

${ }^{34}$ Ibid., p. (3).

35 Ibid., p. (6).

${ }^{36}$ Rivetus' voorwoord tot Biblia sacra, sive Testamentum Vetus, ab Im. Tremellio et Fr. Iunio ex Hebraeo Latine redditum, et Testamentum Novum a Theod. Beza e Graeco in Latinum versum. Amstelodami 1648, fol. A 2 v. 
kon postvatten, dat de textus receptus niet moest worden opgelapt met wat lezingen uit edities met een even dubieuze tekst, maar geheel moest worden opgegeven.

Reeds omstreeks 1600 had Antonius Thysius sr., de latere professor theologie te Harderwijk (1601 - 1619) en Leiden (1619 - 1640), met Scaligers hulp de collaties van tien edities en handschriften van het Nieuwe Testament bijeengebracht in een exemplaar van de editie van Robert Estienne, 1550. In deze uitgaaf waren in de marge al varianten uit veertien manuscripten en de Complutensische Polyglot gedrukt, zodat Thysius lezingen uit zo'n 25 tekstgetuigen bijeen had. ${ }^{37}$ Tot een publicatie van dit materiaal kwam Thysius echter niet.

Op de weg die zou leiden naar de publicatie van omvangrijke variantenverzamelingen in de 18de eeuw (Mills, Bengel, Wettstein), was het een bescheiden stap voorwaarts, toen in 1658 te Amsterdam de editie van het Griekse Nieuwe Testament van Stephanus Curcellaeus verscheen. Curcellaeus ${ }^{38}$ was professor aan het Remonstrants Seminarie te Amsterdam (1643 - 1659), dat in 1634 was opgericht, nadat in 1619 Arminiaanse theologen buiten de universiteit van Leiden waren gesloten. In Curcellaeus' editie ${ }^{39}$ staat onder de textus receptus een groot aantal varianten, geput uit het apparaat van Robert Estienne, uit verscheidene edities en nog vier handschriften. In zijn voorwoord bepleitte Curcellaeus nut en noodzaak van het verzamelen van varianten en wees hij het verwijt van de hand dat dit werk het gezag van de Schrift zou ondermijnen. Doordat hij verzuimde, bij zijn varianten aan te geven uit welke bron zij stamden, was zijn werk slechts van beperkt nut voor latere onderzoekers op hetzelfde gebied. Niettemin heeft Wettstein in Curcellaeus de man geëerd, die de tekstkritiek van het Nieuwe Testament in de 17de eeuw nieuw leven heeft ingeblazen en John Fell en John Mills tot hun edities heeft geïnspireerd. ${ }^{40}$ Aan de betekenis van Curcellaeus' werk heeft ongetwijfeld afgedaan, dat kort voor de verschijning ervan de Londense Polyglot voltooid werd met enige delen waarin het Nieuwe Testament met varianten van de Codex Alexandrinus en een apparaat met lezingen uit bijna dertig handschriften en edities vervat waren (1657).

Nog minder dan Curcellaeus voelde Clericus (Jean Le Clerc) zich aan de textus receptus gebonden. Ook hij was als professor aan het Remonstrants Seminarie verbonden, van 1684 tot 1731, d.w.z. bijna vijftig jaar. ${ }^{41} \mathrm{Hij}$ overleed in 1736 . Het Nieuwe Testament vormde slechts één

37 Thysius' arbeid is bewaard in Leiden U B , 765 A 9, vgl boven n 26

${ }^{38} \mathrm{~J}$ P de Bie en J Loosjes, Biographisch Woordenboek van Protestantsche Godgeleerden in Nederland, II, p $337 \mathrm{vv}$

39 Novum Testamentum Editio nova, in qua diligentıus quam unquam antea, variantes lectiones tam ex manuscriptis quam impressis codicibus collectae et parallela annotata sunt Amstelaedamı $1658 \quad 1675^{2}$

40 Wettstein, Novum Testamentum I, p 172

41 Zie over hem behalve oudere literatuur van o a A Barnes het recente werk van S A. Golden, Jean Le Clerc, New York 1972 (Twayne's World Authors Series 209), dat Clericus vooral tekent als exponent in de wetenschappelıjke, wijsgerige en literaire uitwisselıng tussen Engeland en het continent 


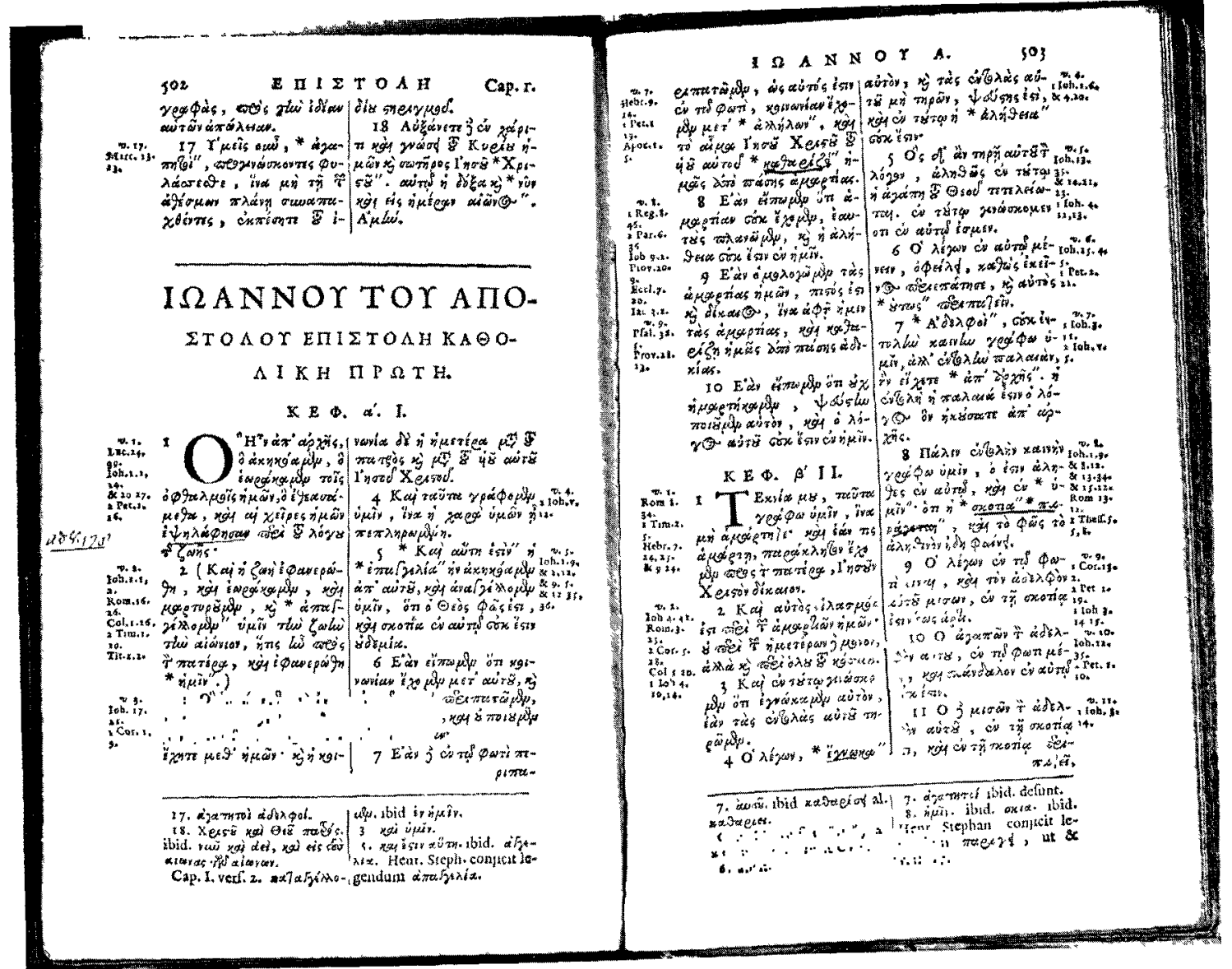

3. Teksteditie van het Nieuwe Testament van Steph. Curcellaeus, Amsterdam $1685^{3}$. Kritisch apparaat onderaan, parallellen in de marges. Schaal $1: 1,4$.

van de zeer talrijke terreinen waarop hij met verbijsterende productiviteit werkzaam is geweest. Aan zijn eigen Franse vertaling van het Nieuwe Testament (1703) had hij het liefst de oude Codex Alexandrinus ten grondslag gelegd. Omdat die nog niet gepubliceerd was, moest hij hiervan afzien. ${ }^{42}$ Bekendheid geniet nog altijd Clericus' conjectuur prôtès in plaats van prôtè tès in Hand. 16:12: ' . . een stad van het eerste district van Macedonië'. Deze lezing, die Clericus zelf uiteindelijk niet heeft durven aanvaarden, werd in de 20ste eeuw voorgestaan door o.m. C. H. Turner, J. M. S. Baljon, E. Preuschen, A. C. Clark, E. Haenchen en door de meerderheid van de redactiecommissie van The United Bible Societies' Greek New Testament. ${ }^{43}$ Belangrijker is ongetwijfeld geweest, dat Cleri-

$42 \mathrm{~J}$. Le Clerc, Le Nouveau Testament traduit sur l'original Grec, Amsterdam 1703, fol. ** 2r. 43 Ik wijt het aan een schrijffout, dat de Nestle-uitgave, die de conjectuur uiterlijk sinds de 12 de editie (1923, ed. Erwin Nestle) vermeldt, haar toeschreef aan 'Crell' i.p.v. aan 'Cler'. W. Bowyer, Critical Conjectures and Observations on the N.T., London $1812^{4}$, p. 383 noemt Artemonius en Le Clerc als autoriteiten. De tenaamstelling is correct in W. Bauer, Wörterbuch zu den Schriften des N.T., s.v. meris, bv. Berlin $1963^{5}$, kol. 999, maar fout in Nestle $26 \mathrm{e}$ dr. ('Turner'). 
kon postvatten, dat de textus receptus net moest worden opgelapt met wat lezıngen uit edities met een even dubieuze tekst, maar geheel moest worden opgegeven

Reeds omstreeks 1600 had Antonius Thysius sr, de latere professor theologie te Harderwık (1601 - 1619) en Leiden (1619 - 1640), met Scalıgers hulp de collaties van tien edities en handschriften van het Nieuwe Testament bijeengebracht in een exemplaar van de editie van Robert Estienne, 1550 In deze uitgaaf waren in de marge al varıanten uit veertien manuscripten en de Complutensische Polyglot gedrukt, zodat Thysius lezingen uit zo'n 25 tekstgetuigen bijeen had ${ }^{37}$ Tot een publicatie van dit materiaal kwam Thysius echter niet

Op de weg die zou leıden naar de publicatıe van omvangrıjke varıantenverzamelingen in de 18de eeuw (Mills, Bengel, Wettstein), was het een bescheiden stap voorwaarts, toen in 1658 te Amsterdam de editıe van het Griekse Nieuwe Testament van Stephanus Curcellaeus verscheen Curcellaeus ${ }^{38}$ was professor aan het Remonstrants Seminarie te Amsterdam (1643 - 1659), dat in 1634 was opgerıcht, nadat in 1619 Armınıaanse theologen buiten de universiteit van Leiden waren gesloten In Curcellaeus' editıe ${ }^{39}$ staat onder de textus receptus een groot aantal varianten, geput uit het apparaat van Robert Estıenne, uit verscheidene editıes en nog vier handschriften In zijn voorwoord bepleitte Curcellaeus nut en noodzaak van het verzamelen van varianten en wees hy het verwijt van de hand dat dit werk het gezag van de Schrift zou ondermijnen Doordat hij verzuimde, bij zljn varianten aan te geven uit welke bron zlj stamden, was zljn werk slechts van beperkt nut voor latere onderzoekers op hetzelfde gebied Niettemin heeft Wettstein in Curcellaeus de man geeerd, die de tekstkritıek van het Nieuwe Testament in de 17 de eeuw nieuw leven heeft ingeblazen en John Fell en John Mills tot hun edities heeft geinspireerd ${ }^{40}$ Aan de betekenis van Curcellaeus' werk heeft ongetwiffeld afgedaan, dat kort voor de verschijning ervan de Londense Polyglot voltooid werd met enige delen waarın het Nieuwe Testament met varianten van de Codex Alexandrinus en een apparaat met lezıngen uit bijna dertig handschriften en editıes vervat waren (1657)

Nog minder dan Curcellaeus voelde Clerıcus (Jean Le Clerc) zıch aan de textus receptus gebonden Ook hy was als professor aan het Remonstrants Semınarie verbonden, van 1684 tot 1731, d w z bijna vijftıg jaar ${ }^{41} \mathrm{H}_{1 \mathrm{j}}$ overleed in 1736 Het Nieuwe Testament vormde slechts één

37 Thysius' arbeid is bewaard in Leiden U B , 765 A 9, vgl boven n 26

${ }^{38} \mathrm{~J}$ P de Bie en J Loosjes, Brographisch Woordenboek van Protestantsche Godgeleerden in Nederland, II, p $337 \mathrm{vv}$

${ }^{39}$ Novum Testamentum Editıo nova, in qua diligentıus quam unquam antea, variantes lectiones tam ex manuscriptıs quam impressis codicibus collectae et parallela annotata sunt Amstelaedamı $1658 \quad 1675^{\circ}$

40 Wettstein, Novum Testamentum I, p 172

${ }^{41} \mathrm{Z}$ e over hem behalve oudere literatuur van o a A Barnes het recente werk van S A Golden, Jean Le Clerc, New York 1972 (Twayne's World Authors Series 209), dat Clerıcus vooral tekent als exponent in de wetenschappelijke, wijsgerige en literaire uitwisseling tussen Engeland en het continent 


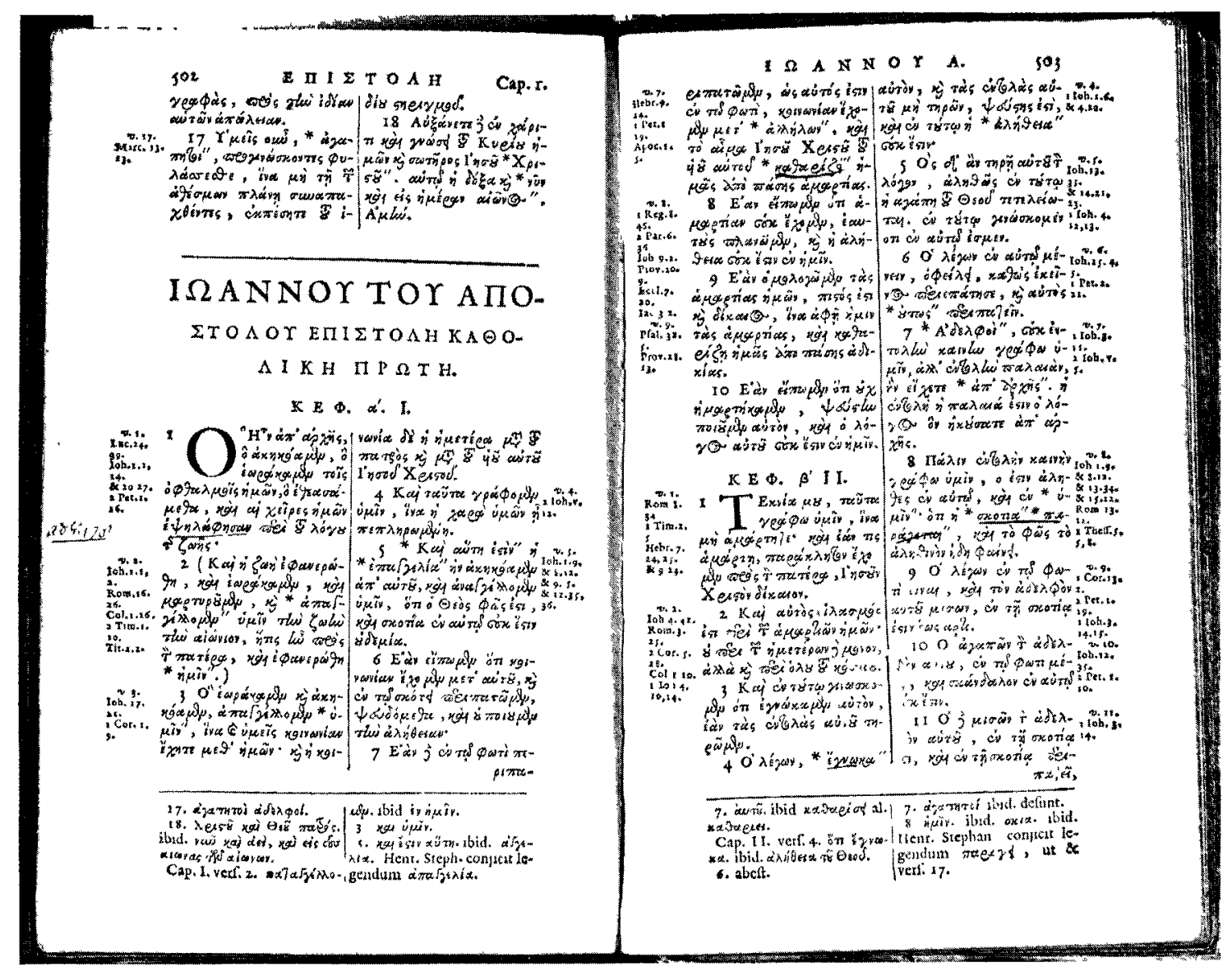

3. Teksteditie van het Nieuwe Testament van Steph. Curcellaeus, Amsterdam $1685^{3}$. Kritisch apparaat onderaan, parallellen in de marges. Schaal $1: 1,4$.

van de zeer talrijke terreinen waarop hij met verbijsterende productiviteit werkzaam is geweest. Aan zijn eigen Franse vertaling van het Nieuwe Testament (1703) had hij het liefst de oude Codex Alexandrinus ten grondslag gelegd. Omdat die nog niet gepubliceerd was, moest hij hiervan afzien. ${ }^{42}$ Bekendheid geniet nog altijd Clericus' conjectuur prôtès in plaats van prôtè tès in Hand. 16:12: ' . . een stad van het eerste district van Macedonië'. Deze lezing, die Clericus zelf uiteindelijk niet heeft durven aanvaarden, werd in de 20 ste eeuw voorgestaan door o.m. C. H. Turner, J. M. S. Baljon, E. Preuschen, A. C. Clark, E. Haenchen en door de meerderheid van de redactiecommissie van The United Bible Societies' Greek New Testament. ${ }^{43}$ Belangrijker is ongetwijfeld geweest, dat Cleri-

42 J. Le Clerc, Le Nouveau Testament traduit sur l'original Grec, Amsterdam 1703, fol. **2r.

43 Ik wijt het aan een schrijffout, dat de Nestle-uitgave, dic de conjectuur uiterlijk sinds de 12de editie (1923, ed. Erwin Nestle) vermeldt, haar toeschreef aan 'Crell' i.p.v. aan 'Cler'. W. Bowyer, Critical Conjectures and Observations on the N.T., London 1812 ", p. 383 noemt Artemonius en Le Clerc als autoriteiten. De tenaamstelling is correct in W. Bauer, Wörterbuch zu den Schriften des N. T., s.v. meris, bv. Berlin $1963^{5}$, kol. 999, maar fout in Nestle $26 \mathrm{e}$ dr. ('Turner'). 
cus in zijn voor het eerst in 1696 gepubliceerde, vaak herdrukte Ars Critica, een systematische beschrijving van de methode der klassieke filologie, er zonder meer van uitging, dat het Nieuwe Testament is overgeleverd met dezelfde risico's van corruptie als elke andere antieke tekst en bij gevolg volgens dezelfde kritische wetten moest worden hersteld. Onder de canones voor de tekstkritiek prijkt hier voor het eerst de regel, dat een lectıoobscurnor meer aanspraak maakt op authenticiteit dan een lectıo clarıor, ${ }^{44}$ een regel overigens die ongeveer tegelijkertijd geformuleerd werd door John Mills (zij het nog niet in een methodisch handboek ${ }^{45}$ ) en waarvan het principe reeds bekend geweest is aan Erasmus. ${ }^{46}$

Noord-nederlandse, veelal Leidse oriëntalisten hebben in de 17 de eeuw ook de belangrijke rol die de oude vertalingen later als getuigen van de nieuwtestamentische tekst zijn gaan spelen helpen voorbereiden door de publicatie van baanbrekende edities. Een Arabische tekst van de Brief aan Titus ${ }^{47}$ werd voor het eerst in druk uitgegeven te Leiden in 1612 door Joh. Antonides (Teunisz.), lector Arabisch aldaar (1612 - 1613). ${ }^{48}$ De uitgaaf diende slechts als leesstof voor beginners in het Arabisch, maar was toch de edıtıo princeps van het betreffende geschrift. De hoogleraar die Antonides opvolgde, Thomas Erpenius (1613 - 1624), publiceerde in 1616 niet minder dan de edıtıo princeps van het complete Nieuwe Testament in het Arabisch. ${ }^{49}$ Lous de Dieu, hervormd predikant en later (1637-1642) Regent van het Waals College te Leiden, gaf in 1627 voor het eerst de Apocalyps uit in de Syrische recensie van Thomas van Heraclea (7de eeuw). ${ }^{50}$ Anoniem belastte De Dieu zich met het ter perse bezorgen en de editoriale begeleıding van de edıtıo princeps van de vier kleınere Katholieke Brieven in de Syrische recensie van Philoxenus (6de eeuw), voor de druk aangeboden door de jonge Engelsman Ed. Pococke, uitgebracht te Leiden in $1630 .^{51}$ Zonder directe relatie met enige hogeschool verschenen in

44 Ars Critica, Pars III, Amstelaedamı 1712, p 293

$45 \mathrm{~J}$ Millus, Novum Testamentum Graecum, Oxonı 1707, ed secunda, Rotterdam 1710, Prolegomena, par 1146

$46 \mathrm{~J} H$ Bentley, 'Erasmus, Jean Le Clerc, and the Princıple of the Harder Readıng', Renaissance Quarterly 31 (1978), pp 309 - 321

47 D Paulı Apostolı Eptstola ad Titum, Arabicè, Cum Ioannis Antoniadae Alcmanant interlınear versione Latınâ ad verbum, [Leıden] In Officına Plantınıana Raphelengı 1612

${ }^{48}$ H F W Wynman, 'Jan Theunisz alıas Joannes Antonıdes (1569-1637) ', Jaarboek Amstelodamum 25 (1928), pp 29 - 122, ıd, 'De Hebraicus Jan Theuniszoon Barbarossıus alias Johannes Antonides als lector van het Arabisch aan de Leidse Universiteit (1612 1613) ', Studia Rosenthaliana 2 (1968), pp 1-29, 149 - 176

49 Novum $D N$ Jesu Christı Testamentum arabice, Leidae 1616 Erpenius baseerde deze uitgaaf als geheel op het door Scalıger aan de Leidse U B nagelaten ms thans Or 217 (van 1342) Voor de evangelıen vergeleek hij bovendien zijn eigen twee mss thans Cambridge Gg v 33 (van 1271) en Gg v 27 (van 1285) Voor Acta en epp had hy voorts ter vergelıkıng een collatie van een door Raphelengius tegen Or 217 vergeleken ms

50 Apocalypszs $S$ Johannts ex manuscripto exemplan è bibliotheca Jos Scaligert deprompto, edita charactere Syro et Ebraeo, cum versione Latına et notıs, Lugdunı Batavorum 1627 De editie berust op een door Scalıger aan de Leidse U B nagelaten ms, thans Or 4735 (van 1580).

51 Epistolae catholicae, Syrace, Latine et Graece ex celeberrimae Bibliothecae Bodleianae Oxoniensis Ms exemplan nunc primum depromptae , Lugdunı Batavorum 1630 
Nederland ook de editiones principes van de evangeliën in het Gotisch (Dordrecht 1665) en van de gehele bijbel in het Armeens (Amsterdam 1666). ${ }^{52}$ In interuniversitaire samenwerking daarentegen bereidden de Utrechtse hoogleraar Hebreeuws en Grieks Joh. Leusden (1650 - 1699) en de Leidse lector Oosterse talen Car. Schaaf (1680 - 1720, hoogleraar tot 1729) een monumentale editie voor van de Syro-Pesjitta van het Nieuwe Testament. ${ }^{53}$ Negen jaar na Leusdens dood verscheen de uitgaaf te Leiden $\left(1708 ; 1717^{2}\right)$; nog Tischendorf citeerde haar voor de vermelding van Pesjitta-lezingen in zijn editio critica octava major van 1872.

Noch een John Mills, noch een Richard Simon is in Nederland opgestaan. Evenmin heeft Noord-Nederland iets voortgebracht dat met de Antwerpse of Londense Polyglot vergelijkbaar is. Leiden zou in de eerste helft van de $17 \mathrm{de}$ eeuw de wetenschappelijke kennis en technische bekwaamheid voor de productie van een polyglot hebben gehad, maar niet het geld, noch voldoende morele steun van het toenmalig establishment: Erpenius' plan voor een polyglot van het Nieuwe Testament strandde in de Dordtse synode. In de tweede helft der eeuw zou Amsterdam wellicht de financiële middelen en de technische capaciteiten hebben gehad, maar het had de kennis niet. Toen in 1657 Waltons polyglot verscheen was de kans op een polyglot uit Holland trouwens definitief verkeken. Maar Curcellaeus' handzame editie in duodecimo, na de eerste druk van 1658 nog drie maal herdrukt $(1675,1685,1699)$, confronteerde misschien meer mensen met het probleem van de variatie in de Griekse tekst dan Waltons polyglot en zal bij velen een heilzame argwaan hebben gewekt. Ook de minutieuze en geduldige arbeid verricht aan de Oosterse vertalingen heeft, afgezien van de waarde die zulke studiën in zichzelf bergen, aanwijsbare impulsen aan toekomstig onderzoek gegeven.

52 Over deze edities, evenals over de in nn. 49 - 51 en 53 genoemde, raadplege men ook B. M. Metzger, The Early Versions of the New Testament, Oxford 1977.

53 Novum Domini Nostri Jesu Chrestz Testamentum Syracum, Lugduni Batavorum 1708, $1717^{2}$. 


\section{MERGII PASORIS,}

Gr. L. Profefloris,

GR A M M A T I C A

G R 2 C A S A C R A

NOVITESTAMENTI

DOMINI NOSTRI JESU

CHALST,

In tres Libros tributa:

In gratiam S.Literarum. \&Lingux Græcx Studioforum.

NUNC PRIMUM

E D I T A.

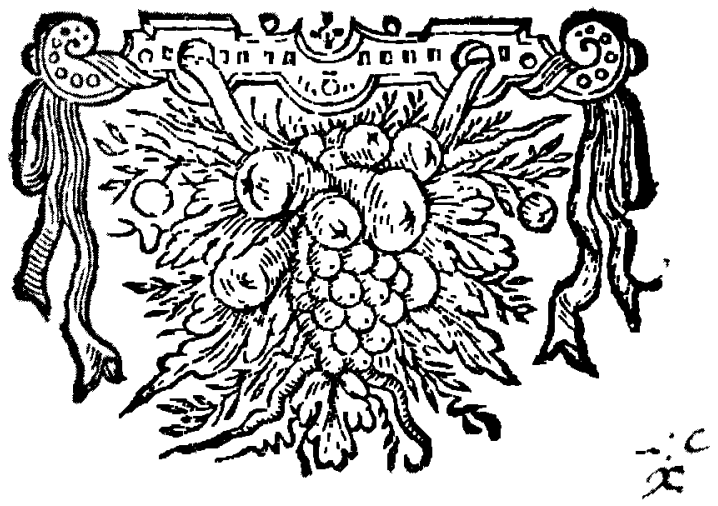

GronING Fristorum,

Typis TOA bus ox.

Amftelredamenfis, apud quem etiam proftat,

$$
\text { Antocio Des }
$$

4 Titelblad van Georg Pasor, Grammatzca Graeca Sacra, Gronıngen 1655, eerste grammatica van het Griekse Nieuwe Testament Schaal 10,75 


\section{Het Grieks van het Nieuwe Testament}

Veel aandacht is in de 17 de eeuw in de Republiek besteed aan het Grieks waarın het Nieuwe Testament geschreven is, en dit op diverse niveaux

Studenten die predikant wilden worden in de Gereformeerde kerk deden doorgaans geen enkel universitair examen, maar moesten vanaf ongeveer 1625 op hun examen voor de classis wel met testımonia van de hoogleraren Hebreeuws en Grieks kunnen aantonen, dat zij het Oude en Nieuwe Testament vlot in het Hebreeuws en Grieks konden lezen, vertalen en grammaticaal verklaren Veelal moesten $z 1$ daarvan ook een proeve afleggen door cursorische vertalıng van ongeprepareerde passages uit beide Testamenten Tot het stellen van deze eis hadden de particulıere synoden van Friesland en Zuıd-Holland besloten naar aanleıdıng van een persoonlyke actıe van de Franeker hoogleraar Hebreeuws Sixtınus Amama (1616 1629), die in een gedrukt vertoog, op beide synoden in vele exemplaren verspreid, met kracht de noodzaak van de kennıs der grondtalen voor dienaren des Woords en van het herstel der erudıtıo trilınguts onder hen had bepleit ${ }^{54}$ Amama's actie had ook elders effect aan alle universiteiten in Noord-Nederland doceerde na 1625 de hoogleraar Grieks in de faculteit der artes nieuwtestamentısch Grieks, soms wellıcht ook Griekse grammatica en syntaxis, ten behoeve van theologische studenten Menigmaal heeft dit Grieks voor theologen het piece de résistance gevormd van de leeropdracht Grieks, dıe dan ook maar al te vaak werd toevertrouwd aan de hebraicus Gezien echter het algemeen verval en de dreigende ondergang van de un1versitaire studie van het Grieks in grote delen van het 17 de-eeuwse Europa, is de haast contınue traditıe van de leeropdrachten Grieks in de Nederlandse universiteiten (hoe vaak ook met andere opdrachten gecombineerd of op lectoraatsniveau vervuld) een positief te waarderen toestand geweest Daaraan, en indirect aan de herleving van de studie van het Grieks in de 18de eeuw, heeft de Gereformeerde kerk het hare bijgedragen door redelijke eisen te stellen aan de intellectuele bekwaamheden van haar voorgangers

Het staat vast, dat de volgende hoogleraren Grieks nieuwtestamentısch Grieks voor theologen hebben gedoceerd Te Franeker G Pasor (1626 -

54 Uitvoeriger wordt op deze zaak ingegaan in Th Lunsingh Scheurleer (ed), Leiden Unversity in the Seventeenth Century, Leiden 1975, pp 6768 
$1637)^{55}$ en Christ. Schotanus $\left(1639\right.$ - 1646) ${ }^{56}$ Te Groningen: Tob. Andreae (1635 - na 1655), ${ }^{57} \mathrm{~J}$. Gousset $\left(1691\right.$ - 1704) ${ }^{58}$ en M. Rossal (1706 1744). ${ }^{59}$ Te Utrecht: Joh. Leusden $\left(1650\right.$ - 1699). ${ }^{60}$ Te Leiden: Jac. Gronovius. ${ }^{61}$ Dat de meeste andere hoogleraren Grieks eveneens nieuwtestamentisch Grieks gegeven hebben, mag men aannemen. ${ }^{62}$

Werden in de 16de eeuw in het academisch onderricht Grieks te Leiden, ${ }^{63}$ en vermoedelijk ook te Franeker, ${ }^{64}$ nog de Griekse grammatica en syntaxis van Nic. Glenardus gebruikt, in de 17de eeuw is in Groningen de Syntaxis graecae linguae en de Polygraphia van J. Posselius (1528 - 1591, hoogleraar te Rostock) in gebruik. Dit leert ons een hoogst interessante blik die Abraham Trommius ons gunt in het 'collegium graecum practicum' zoals professor Andreae dat kort na 1650 te Groningen hield. Trommius verhaalt, ${ }^{65}$ dat Andreae in het Latijn exercitza, wij zouden zeggen 'thema's', samenstelde uit het Latijnse (!) leerboek van Comenius, de Janua linguarum reserata (ca. 1630), en dat de studenten die in het Grieks moesten vertalen met behulp van Posselius' Syntaxis en Polygraphia.

Naast de algemene grammatica's en woordenboeken voor het Grieks waren er in de geschetste omstandigheden, naar zich laat verstaan, speciale hulpmiddelen nodig voor de studie van het Grieks van het Nieuwe Testament. De graecus Georg Pasor, die in 1626 uit Herborn naar de universiteit van Franeker kwam, wordt terecht beschouwd als de grondlegger van zowel de lexicografie als de grammatica van het Griekse Nieuwe Testament. ${ }^{66}$ Nog te Herborn voltooide Pasor zijn Lexicon (1619), het

55 Dit blıjkt uit de praefatio van zıjn zoon tot de Grammatica Graeca Sacra Novi Testamenti, Groningae 1655, p 7

${ }^{56} \mathrm{~J}$ Ros, De Studze van het Bijbelgreksch van $H$ Grotıus tot A Deıssmann, Nijmegen/Utrecht $1940, \mathrm{p} 58$

57 Dit mag wel geconcludeerd worden uit het hieronder te vermelden verslag van Trommius, al noemt die niet expliciet Andreae's lessen over Grieks van het Nieuwe Testament

${ }^{58}$ J G Gerretzen, Schola Hemsterhusiana, Nımegen/Utrecht 1940, p 28

59 Gerretzen, Schola, p 32

60 Dit blıkt uit zıjn didactısch goed bedoelde, maar overıgens soms hoogst bizarre leermateriaal voor de beginner in het nieuwtestamentısch Grieks

61 Blıjkens zujn Dictata ad epıstolam Paulı ad Ephesios, Leiden U B , Ms B P L 2376 Dergelyjke dictaten zijn er van de 18de- en 19de-eeuwse Leidse graecı P Burmannus, $T$ Hemsterhuis, D Ruhnkenıus, L C Valckenaer, J Luzac en D Wyttenbach

62 De Leidse staan opgesomd in Lunsingh Scheurleer, Letden Universtity, p 102, n 58 Voor een 18de-eeuws Utrechts voorbeeld, zie Kernkamp, Acta III, p 84 n 1 (R M van Goens) ${ }^{63}$ Molhuysen, Bronnen I, p 233*

64 W B S Boeles, Freslands Hoogeschool en het Rijks Athenaeum te Franeker, I, Leeuwarden 1878, p 23, waar wel sprake is van het onderwijs Grieks op de Latıjnse scholen, maar aan de hogeschool zal dezelfde grammatica gebruıkt zijn Zie voor in de 17de eeuw gebruikte Griekse grammatica's (waaronder vooral die van G J Vossius domineerde), H W Fortgens, Schola Latina, Zwolle 1958, pp 66 - 68

65 In zyn Bevindingen van hem selven gedurende syn levensloop, Groningen 1720, ook afgedrukt voorin zijn concordantie op de Statenvertaling, Groningen 1750

66 Over Pasor en zijn werk zie men G Delling, 'Das erste griechisch-lateinische Worterbuch zum N T', Novum Testamentum 18 (1976), pp 213 - 240, H Schlosser, 'Die erste Grammatık des neutestamentlichen Griechisch ', in Neutestamentliche Studien fur $G$ Heinnci, Leipzig 1914, pp 252 260, A Deissmann, Licht vom Osten, Tubingen 1923 4, pp 346 - 347, G Friedrich, Theologisches Worterbuch zum $N T$, X, 1(1978), p 8 Cf n 67 
eerste woordenboek op de Griekse tekst, en zijn Etyma (1622), een verklaring van eigennamen en semitische woorden in het Nieuwe Testament. Voorts een beknopte uitgave van zijn woordenboek, het zgn. Manuale (1624), waaraan toegevoegd de Libellus de accentibus Novi Testamenti, een gedetailleerde inleiding in de Griekse accentleer. Uit de tijd van zijn Franeker professoraat dateert eerst de Syllabus (1632), een zeer verkorte versie van zijn woordenboek, niet veel meer dan een Griekse woordenlijst met vermelding van betekenissen in het Latijn, en voorts de Idea Graecarum Novi Testamenti dialectorum (1633), een tractaat waarin de overblijfselen van de oude Griekse dialecten in het nieuwtestamentisch Grieks worden geïnventariseerd. In zijn Franeker periode bleef Pasor deze werken, ook zijn Lexicon en Manuale, steeds voor verbeterde edities bewerken. Na zijn dood (1637) werden $z i j$ nog talrijke malen herdrukt, tot in het laatste kwart der 18de eeuw. ${ }^{67}$

De Griekse grammatica van het Nieuwe Testament die Pasor bij zijn dood in manuscript naliet is waarschijnlijk ontstaan in Franeker. Daarop lijkt o.a. te wijzen, dat hier en daar Griekse taalverschijnselen met analogieën uit het Nederlands worden geillustreerd. Zoals b.v. het Attisch prattô gebruikt in plaats van prassô, kent het Nederlands meten in plaats van messen en dat in plaats van dass (p. 6); en het Griekse woord prochthes is net zo gevormd als het Nederlandse voorgisteren (p. 239). Pas in 1655, achttien jaar na Pasors dood, is deze Grammatica graeca sacra Novi Testamenti door zijn zoon Matthias Pasor, hoogleraar in de theologie te Groningen, gepubliceerd. Het werk telt 785 bladzijden in-octavo en omvat een vormleer, een syntaxis, en een reeks appendices over o.a. de woordvoorraad, de onregelmatige werkwoorden, dialectische verschijnselen en accenten in het Nieuwe Testament, alsmede Griekse stukjes voor oefening in de grammaticale analyse en Latijnse thema's ter vertaling in Grieks proza en metrische poëzie! Het boek houdt rekening met de beginner, vangt dus aan met het alfabet, maar bespaart hem geen detail, ook de in het Nieuwe Testament geheel ontbrekende dualisvormen niet. Pasor citeert royaal voorbeelden uit tal van profane auteurs van Homerus tot Lucianus. De syntaxis is zeer uitvoerig. Geregeld worden afwijkende opvattingen van andere grammatici gesignaleerd. Evenals Pasors andere werken had ook deze grammatica primair een didactisch doel, maar door haar rijkdom aan materiaal en degelijkheid vormde zij een eerste-klas bijdrage aan de filologische studie van het Nieuwe Testament. Dat dit boek nooit is herdrukt, is waarschijnlijk een gevolg van zijn kwaliteit. In de tweede helft van de $17 \mathrm{de}$ eeuw werden de finesses van het Grieks al gauw te moeilijk gevonden. Er is helaas weinig fantasie nodig om zich voor de geest te roepen, hoe zeer de modale student plots gesteld kan zijn op zijn beknopte schoolgrammatica. ${ }^{68}$

67 Zie Dellings artikel. Cf. id., 'Pasor als Lexikograph', Nov. Test. 22 (1980), 184 - 192.

68 Ik signaleer hier nog, dat Pasor op p. 208 de lezer verwijst naar 'notas meas in Syntaxin Posselii'. Hij zal dus ooit Posselius' syntaxis in zijn onderwijs gebruikt hebben en er een bewerking van gemaakt hebben. 
Een tot op de huidige dag omstreden probleem, te weten de aard van het nieuwtestamentisch Grieks, is in de 17de eeuw het onderwerp van ernstige wetenschappelijke strijd en geleerdenruzies geworden. Een hoog oplopende twist speelde zich omstreeks 1640 af tussen de twee grootste coryfeeen van de Leıdse universiteit, Daniel Heınsıus en Claudıus Salmasius. Laatstgenoemde bezette sinds 1633 de ereplaats van Scaliger, wat hem natuurlık nıet innam voor Heinsıus, die wel een voornaam professoraat, dat in de geschiedenis, bekleedde, maar toch slechts een gewone professor was ${ }^{69}$ Men zal begrijpen, dat hun polemiek over het Grieks van het Nieuwe Testament, waarvan hier in het kort verslag moet worden gedaan, niet minder door persoonlijke animositeit dan door wetenschappelijke interesse werd gevoed.

Heinsius had reeds in zijn Arnstarchus sacer van 1627 betoogd, dat de 5deeeuwse christelijke Griekse dichter Nonnus in zijn hexametrische bewerking van het Johannes-evangelie er dikwijls blijk van gaf, onvoldoende met het eigene van de lingua Hellenistıca waarin het evangelie en het overige Nieuwe Testament geschreven is vertrouwd te zijn geweest. Dit eigene zou daarin bestaan, dat deze taal uiterlijk uit Griekse woorden, maar semantisch uit Hebreeuwse en Aramese concepties bestaat. In deze opvatting ging Heinsius zo ver, dat hij in Joh 1:5, 'En het licht scheen in de duisternis, en de duisternis heeft het niet gegrepen', een Aramees woordspel meende op te merken tussen 'duisternis' ( $q^{e} b a l$ ) en 'grijpen' (qabbel). ${ }^{70}$ In zijn Exercitationes sacrae van 1639 duidde Heinsius deze taal van Griekse woorden en semitische concepties aan met de benaming dialectus Hellen tıca, een uitdrukking overigens die reeds Johannes Drusius, de hebraïcus te Franeker, in 1612 incidenteel had gebruikt in een opmerking over Acta 6:1 in zijn Annotationes in totum Jesu Christi Testamentum, sive praeteritorum libr $X X^{71}$ Met de term 'Hellenistisch dialect' doelde Heinsius op het idioom van de zogenaamde 'Hellenisten'. Hellenisten waren, sinds Scaliger deze term had geijkt en de erdoor aangeduide categorie had gedefinieerd en geprofileerd. joden, en alleen joden, die geen Hebreeuws of Aramees kenden, het Oude Testament slechts in de Septuagınt konden lezen, en uitsluitend Grieks spraken en schreven. Tot hen rekende Scaliger bij voorbeeld Philo, de auteurs van II Maccabeeen en van de toevoegsels Susanna en Bel bij Daniël, Paulus, de evangelisten en de schrijver van de brief aan

69 Professoren waren in de $16 \mathrm{de}, 17 \mathrm{de}$ en $18 \mathrm{de}$ eeuw geenszins een byzonder hoog geschatte maatschappelıjke groep De amateur, de erudiet, de gentleman die reisde en aan hoven en in kabinetten en salons verkeerde had maatschappelıjk meer prestige (W S M Knight, The Life and Works of Hugo Grotzus, London 1925, p 15) Vooral in Holland genoten professoren betrekkelijk weinig achting $(\mathrm{H}$ L Benthem, Hollandischer Kirch und Schulen-Staat, Frankfurt/Leipzig 1698, II, p 53) Salmasius deponeerde dan ook een heftig protest bij de Leidse curatoren toen 1emand van hem gesproken had als 'professor honorarıus' die titel achtte hy ver beneden zın waardigheid (Molhuysen, Bronnen, II, p $\left.350^{*}\right)$

$70 \mathrm{~J}$ Levy, Chaldarsches Worterbuch uber die Targumım, II, Leıpzig 1868, p 341, noemt voor q bal o a Targum Onqelos op Gen 1512 en 17

71 In hetzelfde werk gebruikt Drusıus de uitdrukkıng 'lingua Hellenıstıca', in een commentaar op Lucas 1518 
de Hebreeen Heinsius nu ging een stap verder dan Scaliger en verbond met de categorıe van de Hellenisten (griekstalige joden) het idee van een specifiek aan de Hellenısten eigen trant van spreken en schrijven de dialectus Hellenistica, een taal van Griekse woorden, maar met semitische betekenissen, die men vooral uit de targumim moest leren kennen In zijn Exercitationes sacrae vermeldt Heinsius voortdurend de Aramese en Hebreeuwse equivalenten van Griekse woorden en wendingen uit het Nieuwe Testament, ten einde de Aramese of Hebreeuwse noties en connotaties die zijns inzıens onder het Griekse oppervlak van de dialectus Hellenistıca schuil gaan in het licht te stellen

Van Salmasius' kant verschenen aanvallen op Heinsıus' standpunt in de praefatie tot zijn De modo usurarum van 1639, in De Hellenistzca commentarius van 1643 en in zıjn Funus linguae Hellentstıcae, eveneens van 1643 Steun kreeg Salmasius in zın strıd tegen Heınsıus vanuit Genève, waar $J$ de Croy tegen Heinsius' visie op de 'dialectus Hellenistica' te keer ging in zun Sacrae et historicae in Novum Foedus observationes van 1644 De verded1ging van Heinsius werd gevoerd in een Exercıtatıo prima de Hellenistis et lingua Hellenistıca, van de hand van de veelzıjdige Groningse hoogleraar in de filosofie M Schoockius, doch anoniem verschenen te Utrecht in 1641 Aan de bittere polemiek kwam een einde doordat de Leidse curatoren Heinsius en Salmasius tot een formele verzoening wisten te bewegen de door beiden ondertekende overeenkomst is bewaard gebleven ${ }^{72}$ Tegen De Croy verweerde Heinsius zich nog met een Apologia in $1646^{73}$

Wat Salmasius tegen Heinsius inbrengt komt hierop neer, dat volgens hem het Grieks van het Nieuwe Testament noch een 'dialectus', noch 'Hellenistisch' is geweest Het is geen dialect, omdat het niet de taal van een bepaalde volksstam of van een bepaald gebied is en net Hellenistisch, omdat het deel uitmaakte van de contemporaine Griekse wereldtaal en er geen Hellenıstische natie of stam is geweest die aan deze taal zijn naam heeft kunnen geven, zoals Ioniers aan het Ionısch en Doriers aan het Dorisch Salmasius was het met Heinsıus eens, dat in het Nieuwe Testament tal van woorden Grieks van uiterlıjk, maar semitısch van betekenıs en connotatie waren, hij verklaarde dit fenomeen echter anders Volgens hem waren alle geschriften van het Nieuwe Testament, behalve die van Lucas en Paulus, ut het Hebreeuws of Aramees vertaald en deed de sem1tische achtergrond van de oorspronkelıjke teksten zich in de Griekse versies gelden Lucas en Paulus hadden wel in het Grieks geschreven, maar doordat zij tweetalıg waren hadden zij, net als de vertalers van de overige

72 Molhuysen, Bronnen, II, p 343* (februarı 1644)

73 Kort zijn over de affaire G B Winer, Grammatık des Ntlıchen Sprachidioms , 6 Aufl, Leipzig 1855, pp 26 - 27 met de noten, Aem Springhettı, Introductio HistorcaGrammatica in Graecitatem Nou Testament, Romae 1966, 37 - 38 Voor het kader Ros, Studie van het Bybelgrieksch, pp 14 - 15 (teleurstellend kort) en 60, n 18 In Ros' literatuurlysst ontbreken zowel Salmasius' De modo usurarum en Funus, als Schoockius' Exercatatıo prima Zie ook D J H ter Horst, Daneel Heinszus (1580 1655), Utrecht 1934, pp 132137 en vooral Richard Simon, Historre critrque du texte du Nouveau Testament, Rotterdam 1689, pp 315 - 335, voorts onze Appendix I hierna 
nieuwtestamentische geschriften, een Grieks met semitische inslag geproduceerd.

Herhaaldelijk is opgemerkt, dat de strijd tussen Heinsius en Salmasius slechts over woorden ging, met name over de termen 'dialect' en 'Hellenistisch' en hun geschiktheid voor de karakterisering van het nieuwtestamentisch Grieks. Inderdaad lijkt Salmasius er vooral op uit, de onbruikbaarheid van die termen te bewijzen en hierin is wellicht de zwakke stee in zijn offensief gelegen. De Griekse term dialektos is door antieke auteurs zeker niet alleen gebruikt voor 'taal van een bepaalde volksstam of natie', 'taal van een bepaalde streek', maar evenzeer voor 'dictie', 'stijl' (bij voorbeeld: een dichterlijke dialektos), 'idioom', 'spreektrant', 'bepaalde verschijningsvorm of variant van een taal', dit laatste bij voorbeeld in de uitdrukking koinè dialektos als gebruikt door Diodorus Siculus (I, 16) in de eerste eeuw v. Chr. Heinsius' gebruik van de term is dus niet ongerechtvaardigd. Ook de term 'Hellenistisch' is, zij het in een geheel andere betekenis dan bij Heinsius (namelijk in uitsluitend chronologische zin), uiteindelijk de best bruikbare gebleken voor de aanduiding van het Grieks waarin de nieuwtestamentische geschriften gesteld zijn: 'Hellenistisch' en 'textus receptus' zijn de grote terminologische successen van Heinsius op nieuwtestamentisch gebied. Maar er is, zoals Salmasius ook zelf geaccentueerd heeft, tussen hem en Heinsius niet slechts een meningsverschil over termen, maar wel degelijk ook over historische zaken. Het eigenlijke verschil van opvatting betrof de vraag, of het semitiserend Grieks van het Nieuwe Testament al dan niet buiten de geschriften waarin men het ontmoet zelfstandig en enigszins duurzaam bestaan heeft. Heinsius beschouwde dit type Grieks als een verschijnsel dat rondom de aanvang van de eerste eeuw gedurende een zekere periode een zelfstandige grootheid had gevormd. Salmasius daarentegen zag de in dit semitiserende Grieks geschreven geschriften als incidentele resultaten van vertaling of tweetaligheid: deze taal had niet een zelfstandig bestaan gekend, maar kon nu en dan te voorschijn komen als resultaat van vertaling van Hebreeuwse of Aramese geschriften in het Grieks, of als effect van tweetaligheid bij sommige joden. Voorts was volgens Salmasius dit Grieks in principe niets dan de algemeen verbreide Griekse taal zoals die na Alexander in een groot deel van de oude wereld gesproken werd. Dit inzicht is van gewicht. Terwijl achteraf gezien Heinsius zijn 'Hellenistisch dialect' veel te scherp isoleerde van het overige contemporaine Grieks en overdreven intensief Griekse nieuwtestamentische woorden trachtte toe te lichten door Hebreeuwse, Aramese en Syrische equivalenten aan te voeren, toonde Salmasius een wonderlijk correct begrip voor de organische samenhang van het Grieks binnen het Nieuwe Testament met dat erbuiten, vooral niet-literair profaan Grieks. Overigens is Salmasius' verklaring voor de semitische inslag in het nieuwtestamentisch Grieks als effect van vertaling of tweetaligheid slechts in zeer beperkte mate, en in een zin die hij nog niet bevroedde, ${ }^{74}$ juist. Ook is het de vraag, of Salmasius niet al te drastisch

74 Voor geen van de geschriften van het Nieuwe Testament behoeft te worden aangenomen, dat het als geheel uit een semitische taal in het Grieks is vertaald. Maar 
heeft willen afrekenen met het min of meer semitiserende Grieks als zelfstandige historische entiteit. Maar zoveel moge duidelijk zijn: Heinsius en Salmasius streden over een serieus wetenschappelijk probleem.

Een andere strijd, zowel binnen als buiten de Nederlanden gevoerd, staat bekend als die van hebraisten en puristen en betrof eveneens de aard van het Grieks van het Nieuwe Testament. ${ }^{75}$ In de 16 de eeuw en het begin van de 17 de eeuw waren geleerden als Erasmus, Castellio, Beza en Drusius niet blind geweest voor het feit dat in het Griekse Nieuwe Testament heel wat taalkundige onzuiverheden en hebraïsmen voorkomen. Toen in het 17 de-eeuwse protestantisme het vacuum dat ontstaan was door de afschaffing van het kerkelijk leergezag zich vulde met een steeds massievere leer van de verbale inspiratie der Schrift, ontstond voor velen het probleem: hoe kan de bijbel, indien van woord tot woord geïnspireerd, grammaticale onzuiverheden bevatten? Dat het probleem door de confrontatie van incompatibele gegevens als filologische constateringen en dogmatische opvattingen zijn, vals gesteld was, zag nog niemand in.

Vanaf het tweede kwart van de 17 de eeuw, toen het slechte Grieks in Gods woord een urgent probleem begon te worden, gingen de opvattingen van hen die de kwestie trachtten op te lossen in twee richtingen uiteen. Sommigen waren bereid, de aanwezigheid van hebraïsmen te erkennen, maar beschouwden deze niet als barbarımen, doch als sieraden die aan het Grieks van het Nieuwe Testament zijn religieuze luister en waardigheid gaven en die nodig waren om de bijzonderheden en diepten van de goddelijke inhoud adequaat tot uitdrukking te brengen. Klassiek Grieks zou hiertoe te kort geschoten zijn. Deze zienswijze is die der zogenaamde hebraïsten. Tegenover hen stonden de zogenaamde puristen, die geheel of tot op grote hoogte ontkenden, dat het Nieuwe Testament ontsierd werd door barbarismen en grammaticale onvolkomenheden: zoveel mogelijk probeerden zij de hebraïsmen die hun tegenstanders aanwezen als correct Grieks voor te stellen door er parallellen naast te leggen uit niet-bijbelse Griekse (en ook wel klassieke Latijnse) bronnen.

De internationale polemiek tussen puristen en hebraïsten - waarvan hier slechts het Nederlandse toneel geschetst wordt - werd in 1629 ingeleid door de in Amsterdam uitgegeven Diatribe de linguae Graecae purtate van Sebastiaan Pfochen. De auteur, een leerling van Pasor in Franeker, ont-

bepaalde individuele klemere teksteenheden, zoals sommige woorden van Jezus, kunnen in een vroeg overleverıngsstadıum van Aramees of Hebreeuws in het Grieks zunn overgebracht en daarbi] semitismen hebben opgelopen Deze kunnen zowel op het niveau van woordkeus en syntaxıs, als op dat van de betekenıs liggen Zulke aan vertaling te wijten semitısmen zullen echter gemeenlıjk ontstaan zınn vóórdat de evangelisten hun werk deden - Of semitısmen het gevolg van tweetalıgheıd zıjn, valt dáárdoor moeilık uit te maken, dat die tweetaligheid zelf niet bewijsbaar is

${ }^{75}$ D G Morhofius, Polyhistor, Lubeck $1732^{3}$, I, pp $790-791$ (tevens over het geschil Heinsius-Salmasius pp 788 - 789) J F Buddaeus, Isagoge, Lipsiae 1730, pp 1302 -1303 Winer, Grammatık, pp $11-18$ Ros, Studie van het Bijbelgrieksch, pp 12 - 20 Springhettı, Introductıo, pp 34 - 46, P Vullıaud, La clé traditıonnelle des Evangiles, Parıs 1936, chap I J Irmscher, 'Der Streit um das Bibelgriechisch', Acta Antıqua Academiae Sctentiarum Hungancae 7 (1959), pp 127 - 134 Friedrich, Theologisches Worterbuch, X, pp $23-27$ 
kent dat in het Nieuwe Testament hebraïsmen voorkomen en wil bewijzen, dat voor zover hebraïsmen zijn verondersteld, deze evenzeer bij profane Griekse schrijvers te vinden zijn. Misschien in reactie op Heinsius, die in zijn Aristarchus van 1627 geschreven had, dat Plato en Aristoteles het Nieuwe Testament vanwege zijn oriëntaalse, semitiserende stijl niet zouden hebben kunnen begrijpen, stelt Pfochen, dat dit Grieks begrijpelijk zou zijn geweest voor Homerus, Demosthenes en andere Grieken: het is van klassieke zuiverheid.

Dit radicale standpunt van Pfochen, dat in 1648 een uitvoerige bestrijding heeft gevonden in een De Novi Instrumenti stylo dissertatio van de Engelse theoloog en graecus Thomas Gataker, werd in de Nederlanden slechts door zeer weinigen gedeeld. Johannes Coccejus, toen nog Pfochens medestudent te Franeker, in wedijver met en tegen wie hij zijn Diatribe geschreven schijnt te hebben, ${ }^{76}$ schreef eveneens in 1629 in de inleiding tot zijn Duo tztul Thalmudrce, Sanhedrn et Maccoth, dat de apostelen het Griekse dialect van de synagoge hadden geschreven. De betekenissen en bijbetekenissen van de woorden waren in dit Grieks, aldus Coccejus, vervormd naar de aard van het Aramees, zodat dit bijzondere dialect zich verre van de antieke spreekwijze der Grieken verwijderd had en kennis van de Talmud tot het verstaan van het Nieuwe Testament veel bijdraagt. ${ }^{77}$ Pfochens leermeester Pasor gaf in zijn Idea van 1632 als zijn mening te kennen, dat in het Nieuwe Testament vele hebraïsmen voorkomen, ook al wilde hij het nieuwtestamentisch Grieks daarom nog niet 'onzuiver' noemen.

In Leiden was Heinsius dezelfde opvatting als Pasor toegedaan: dit hebraiserende Grieks diende om de volle zin van wat bedoeld werd uit te drukken. Hij ontkende overigens niet, dat ook profaan Grieks tot het verstaan van het Nieuwe Testament kon bijdragen. ${ }^{78}$ Ondanks het diepgaand meningsverschil dat tussen Heinsius en Salmasius bestond over de vraag of een semitistisch Grieks als in het Nieuwe Testament wordt aangetroffen ooit als zelfstandige tongval bestaan had en door een bepaalde groep joden gesproken was, waren beiden het eens over de aanwezigheid van semitismen in het Nieuwe Testament en beiden moeten als hebraïsten worden beschouwd. Dit geldt als vanzelf ook voor Constantin L'Empereur, de Leidse hoogleraar Hebreeuws sinds 1627, later ook in het Aramees, van 1646 tot 1648 uitsluitend in de theologie. In de inleiding tot zijn De legibus Ebraeorum van 1637 beveelt hij de studie van de Misjna aan, omdat men hierin de stijl en dictie van de geschriften van het Nieuwe Testament ontmoet. Want weliswaar zijn Alexander en de diadochen erin geslaagd het Grieks ingang te doen vinden bij de onderworpen joden, maar daarbij

${ }^{76}$ Ros, Studie van het Bybelgreksch, p 12

$77 \mathrm{G}$ van Gorkom, De J Coccejo s Codicıs interprete, Utrecht 1856, p 8 Coccejus heeft op Pfochens Diatribe nooit een weerwoord gepubliceerd, doch wel korte Stracturae bij Pfochens vertoog nagelaten, die pas in 1701 door Rhenferdius in zljn onder te noemen Syntagma zıjn gepubliceerd

78 Exerctationes sacrae, Prolegomena, p 34 'scriptoribus profanis et hic locus esse potest' De pp $20-34$ bieden Heinsius' visie op het Grieks van het N T, voor een samenvatting Th Lunsingh Scheurleer ed, pp $95-96$ 
heeft de volkstaal van de onderworpenen allerlei connotaties van haar eigen woorden, stilistische, syntactische en semantische eigenaardigheden overgedragen op het Grieks. Dit Grieks heeft zo zijn elegantie verloren, al kan aan het 'Hellenistisch' (d.w.z. joods-griekse) taaleigen een eigen elegantie niet worden ontzegd.

Hebraïsten waren voorts: te Groningen M. Schoockius blijkens zijn Exercitatıo prima de Hellenıstıs et lingua Hellenıstica van 1641, te Utrecht Joh. Leusden blijkens zijn Phlologus Hebraeo-Graecus van 1670 en te Franeker de in 1682 tot gewoon hoogleraar Hebreeuws en oosterse talen benoemde Jac. Rhenferd. De laatste liet zijn leerling Moses Solanus een Dissertatıo philologica de stylo Novi Testamentı contra Seb Pfochenıum (Franeker 1696) schrijven. Rhenferd gaf zelf in 1702 te Leeuwarden zijn Syntagma uit, een bundel studies van vroegere auteurs uit zowel het puristische als het hebraïstische kamp, waaraan hij een eigen verhandeling van hebraïstische signatuur over de wending 'de toekomende eeuw', ho azoon ho melloon, toevoegde.

Het zou kunnen lijken dat in de Nederlanden, anders dan in Duitsland, de hebraïsten het terrein volkomen beheersten. Dit beeld behoeft echter enige modificering. Ten eerste dient vermeld, dat een jaar na de verschijning van het evenwichtig samengestelde Syntagma van Rhenferd, de Amsterdamse predikant Van den Honert eveneens een Syntagma dissertationum de stylo Novi Testamentı graeco publiceerde, waarin overwegend puristisch georiënteerde bijdragen van o.a. Van den Honert zelf verzameld waren. Volgens hem is de stijl van het Nieuwe Testament zuiver en volmaakt. Hij erkent wel, dat er hebraïsmen in het Nieuwe Testament voorkomen. Dit zijn echter geenszins barbarismen, noch taalfouten of stijlgebreken, aangezien ze voor de vertolking van de inhoud noodzakelijke, onvermijdelijke termen zijn, waarvan ook de Attische redenaars zich zouden hebben bediend als ze hetzelfde te zeggen hadden gehad. Veel als hebraïsmen aangeziene wendingen zijn bovendien evenzeer gebruikt door profane Griekse auteurs: het aantal hebraïsmen kan aanzienlijk worden gereduceerd. Van den Honert werd in 1714 hoogleraar theologie in Leiden (-1734), waardoor het gematigd purisme een academisch steunpunt kreeg, trouwens niet het eerste.

Ten tweede immers moge worden aangestipt, dat een soortgelijk getemperd purisme gedurende de 18de eeuw een nieuw, karakteristiek en productief genre wetenschappelijke literatuur heeft voortgebracht, de zogenaamde observationes-literatuur. Tientallen boeken zagen het licht, vooral in Duitsland, maar ook hier te lande, waarin parallellen tussen de taal van het Nieuwe Testament en andere antieke Griekse geschriften werden geregistreerd. Ze zijn veelal zo ingericht, dat ze uit één enkele Griekse auteur parallellen bij het Nieuwe Testament bieden; vaak dragen ze dan titels als: Observatzones in Novum Testamentum ex , bij voorbeeld Flavio Josepho ${ }^{79}$ Maar ook kunnen plaatsen uit een veelheid van antieke auteurs worden

79 Dit werk, van de hand van Jo Tobıas Krebsius, verscheen te Leipzig in 1755 Vele titels uit de observationes-literatuur worden opgesomd in de biblografie van Ros, Studue van het Bijbelgrieksch, pp 49 - 56 en in Springhettı, Introductio, pp $45-47$ 
aangevoerd ter illustratie van het nieuwtestamentisch taalgebruik. Misschien het vroegste specimen van dit tweede type observationes is een werk van de Franeker hoogleraar Grieks Lambertus Bos (1704 - 1717), Exercitationes philologicae in quibus Novi Foederis loca nonnulla ex auctoribus Graecis illustrantur et exponuntur (Franequerae $1700 ; 1713^{2}$ ). Tot hetzelfde type behoren de Observationes philologicae in sacros Novi Foederis libros (Lugduni Batavorum 1725) van Joa. Alberti, later hoogleraar theologie te Leiden (1740 1762). Ontdaan van Pfochens overdrijving is het 'purisme' een hechte en zinvolle wetenschappelijke traditie geworden, met zekere variaties voortgezet tot op de huidige dag. 


\section{De filologische verklaring van het Nieurve Testament}

Niet om thesen of lessen of philosophische verklaringen is het te doen, maar om de eenvoudige beteekenis der dingen in hun tigd J. Huizinga, recensie op P Hazard, La crise de la Conscience Européenne, in Verzamelde Werken, IV, Haarlem 1949, p. 338 .

Hier is het de plaats om aan de uitlegging zelf, met name aan de commentaren enige aandacht te wijden. De vernieuwing die op dit gebied in de 16 de en 17 de eeuw plaats had, tekent zich het duidelijkst af in de opkomst en bloei van de filologische annotationes-commentaar. Deze ontwikkelde zich naast de nog volop vitale theologische commentaar. Het onderscheid tussen de twee is aanzienlijk ${ }^{80}$ De theologische commentaar analyseert; hij poogt in de tekst als geheel, zijn onderdelen, de woorden en woordbetekenissen door te dringen door die uiteen te leggen en door daarin gedurig verdergaand onderscheid aan te brengen tussen elementen en facetten die vaak niet in de tekst gegeven, zelfs niet verondersteld zijn, maar die de theoloog-commentator nu eenmaal nodig heeft voor de stoffering van zijn eigen moderne theologische leerstelsel. De verlangde bijzonderheden worden uit de tekst opgedolven middels een ondervraging die schijnbaar zeer technisch is, doordat ze opereert met aan de retoriek, logica en dialectiek ontleende categorieën, maar in werkelijkheid zeer subjectief, doordat aan de Schrift steeds precies die dogmatiek wordt ontlokt die de exegeet vooraf al aanhing. In laatste instantie is dogmatische exegese een rijkelijk vicieus proces: het levert de exegeet op wat hij wil en wat hij al wist. De annotationes-commentaar, geschapen door Valla en Erasmus, analyseert niet zozeer, maar belicht; hij licht de bijbeltekst toe met gegevens uit naburige literatuur.

De theologische commentaar is voorts meestal (Gomarus is een gunstige uitzondering) buitensporig breedvoerig, mede doordat het enige omslag vergt alvorens uit de oude bijbeltekst gedetailleerde actuele dogmatische zienswijzen zijn voortgebracht. Hiertoe zijn gedurig excursen nodig, waarin ver doorgevoerde analysen een plaats vinden, maar ook de bestrijding van afwijkende theologische visies uit heden en verleden en soms ook uiteenzettingen over de betekenis van het bereikte resultaat voor de praktijk van de prediking, bij voorbeeld voor de paraenese. Daarentegen bestaat de filologische commentaar uit korte losse opmerkingen, citaten uit antieke bronnen, vermelding van afwijkende lezingen en vertalingen,

80 Even aanzienlijk is daarom de verbreide misvatting, dat bij voorbeeld de Exercitationes sacrae van Heinsius een 'theologisch' werk zouden zijn. In de context van hun tijd en tegen de achtergrond van wat toenmaals een theologische commentaar was moeten de Exercitationes juist als niet-theologische schriftuitlegging, als filologie worden beschouwd Men noemde deze wetenschap toen: philologia sacra of critzca sacra 
kortom, allerhande literair-historische informatie vervat in beknopte mededelingen. Deze hangen onderling niet of weinig samen; hun eenheid ligt slechts in de bijbeltekst die ze illustreren.

Terwijl de theologische commentaren de Schrift geschikt maken voor modern dogmatisch gebruik, maken de filologische commentaren haar verstaanbaar als antiek document. In theologische commentaren wordt het behandelde bijbelboek doorgaans als een samenhangend, gestructureerd geheel beschouwd; onderdelen worden gezien in relatie tot het geheel. In de filologische commentaren wordt de bijbeltekst niet in zijn geheel behandeld, maar details worden geselecteerd, op zichzelf beschouwd en als detail toegelicht, terwijl andere tekstgedeelten geheel onbesproken worden gelaten. Een visie op een bijbelboek als geheel en op het oogmerk ervan is in filologische commentaren zelden expliciet aan de orde; zo'n kijk op het geheel behoort tot de verzwegen vooronderstellingen van de commentator. Deze beschouwt het bijbelboek, heel sober, als een geschrift uit een ver verleden waarin een antieke auteur zich met een historisch bepaalde bedoeling tot een bepaald publiek van zijn tijd heeft gericht. Die bedoeling van de auteur meende de filoloog in hoofdzaak bekend te mogen veronderstellen: hij gaat er nauwelijks op in en brengt de door hem verklaarde bijzonderheden van de tekst er niet steeds mee in verband.

Elk op hun eigen manier lijken de theologische en de filologische commentatoren een groot vertrouwen in de verstaanbaarheid van de bijbel te hebben gehad en zich in beginsel met de daarin besloten liggende wereld vertrouwd te hebben gevoeld. De theologen hebben niet de geringste moeite om in de Schrift hun theologie terug te vinden. De 17de-eeuwse filologen lijken van hun kant in het algemeen geen onoverkomelijke problemen te zien in de literair-historische vragen (men zou nu zeggen: de 'Einleitung') van de bijbelboeken, noch zien zij een serieus probleem in de vroegchristelijke theologie, haar eenheid en verscheidenheid en haar ontwikkeling. Met hun globale onuitgesproken opvattingen stelden zij zich tevreden. Veel filologen wisten zich door hun studie van oude talen en literaturen zo goed in het verleden te verplaatsen en te bewegen, dat ze het Nieuwe Testament niet als een hun vreemde wereld ervoeren, maar er zich tot op grote hoogte mee verwant voelden. $\mathrm{Zij}$ gingen er eenvoudig van uit, dat het Nieuwe Testament over het geheel genomen redelijk toegankelijk is en historisch en theologisch verstaanbaar is; het zijn slechts de details waarover nieuw licht kan worden ontstoken en daarop legden zij zich toe.

Was de methode van de theologische tekstverklaring in wezen de analyse, die van de filologische benadering was: vergelijking - vergelijking met andere antieke literatuur. Drie complexen van oude literaire bronnen kwamen voor dit vergelijken in eerste instantie in aanmerking:

a. de oude Hebreeuwse en joodse literatuur;

b. de oude vertalingen van het Nieuwe Testament;

c. de exegese der kerkvaders.

Tot het eerste complex behoren behalve het Oude Testament in het 
Hebreeuws en in het Grieks, de pseudepigrafen, Philo en Josephus, de targumim, de talmud en de overige omvangrijke rabbijnse literatuur. Illustratief materiaal uit dit gebied werd voor het eerst op enigszins uitgebreide schaal aangedragen door de Vlaming Johannes Drusius, eerst professor in het Hebreeuws, Aramees en Syrisch te Oxford (1572 - 1576), vervolgens in dezelfde talen te Leiden (1577 - 1584) en tenslotte in de Hebreeuwse taal en oudheden te Franeker $\left(1585\right.$ - 1616). ${ }^{81}$ Van de talrijke werken ${ }^{82}$ waarin hij zich met de verklaring van het Nieuwe Testament heeft bezig gehouden, zij hier slechts genoemd zijn Annotatıones in totum Jesu Christı Testamentum, sive Praeteritorum libr decem (Franekerae 1612). Hieruit volgen hier in vertaling enkele passages die van Drusius' exegese een indruk geven.

Bij Mt. 22:39 'Het tweede (gebod) echter, hieraan gelijk, is: Gij zult uw naaste liefhebben als uzelf' (Lev. 19:18) merkt Drusius op:

"Dit is immers de grote en algemene regel. ${ }^{83}$ In het commentaar op het boek Aboth, hoofdstuk 3, staat: 'Gij zult uw naaste liefhebben als uzelf: de algemene samenvatting van de ganse wet, zoals gevonden wordt in het tractaat Sjabbath over Hillel, die de ganse wet onderwees door middel van één enkele algemene regel: Heb uw naaste lief, enz.'

De schrijver van het boek Musar zegt in hoofdstuk 18: 'Een heiden ${ }^{84}$ kwam bij de oude Sjammai en zei tegen hem: Maak mij een proseliet, op deze voorwaarde echter, dat gij mij de wet leert in de tijd gedurende welke ik op één voet kan staan, of middels één enkele algemene regel. Sjammai joeg hem weg met een meetlat die hij in zijn hand had. De heiden kwam bij de oude Hillel, die hem proseliet maakte, want hij onderwees hem de wet in de tijd gedurende welke hij op één voet kon staan of in één enkele algemene regel. Gij zult uw naaste liefhebben als uzelf'.

Dezelfde schrijver zegt in hetzelfde hoofdstuk: 'Wie de schepselen liefheeft, het is als hield hij de ganse wet'. En verder: 'Gij zult uw naaste, enz. Rabbi Aqiba zegt: Dit is de grote algemene regel in de wet'.

Voorts het commentaar op Aboth: 'De vrome houdt deze regel: Gij zult uw naaste liefhebben, enz., wat de grote algemene regel is in de wet. Want

81 Over Drusıus zıe men Lebram, 'Hebraische Studıen', pp 330 - 341, alwaar verdere literatuur wordt opgegeven Voor Drusius' portret, R E O Ekkart, Franeker Professorenportretten, Franeker 1977, p 53 In dit prachtige album, dat het lllustere Athenae Frisiacae als tot leven brengt, ontmoet men o a ook Pasor, Amama, Coccejus, Witsius, A Marck, C Vitrınga pater, Perızonıus, Rhenferd en L Bos

82 Voor hun bibliografie Lebram, 'Hebraische Studien', noot 55 De Praetertia zijn opgenomen in de Cntıcı Sacn, ed J Pearson e a, Londen 1660, VI en VII, 13 andere werken in VIII Men vindt een en ander ook in de editıes Frankfurt 1695 en Amsterdam 1698

83 Deze eerste woorden van Drusius zijn, wat hij niet doet uitkomen, citaat op naam van rabbı Aqiba in Siphra Levitıcus 19 18, zie Strack/Bıllerbeck, Kommentar zum Neuen Testament aus Talmud und Midrasch, I, Munchen 1926, p 907 en 357, alwaar parallelplaatsen

84 De nu volgende anecdote komt, met een belangrıjke varıant in Hillels samenvattıng van de wet (gulden regel in plaats van liefdegebod), voor in de Babylonische talmud, Sjabbath $31 \mathrm{a}$, cf Billerbeck, I, p 357 


\section{Mate. 16.}

Hoc caput libri Gracix olim non habebant. Hièro: nym.epift. 149. queef. 3. Omines peene Grasia libri boc capi. zulum in fone non babens. Zacharias Chryfopolitanus epifcopus, pag. 364. ubi $\&$ de loco illo verf. 2 . valde mane. Vide de illo etiam Hieron, loco citato. Matthæus habet, fero Sabbatbi, quo extrema pars fabbathi fignifica-

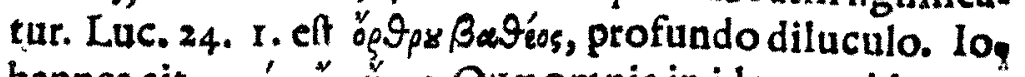

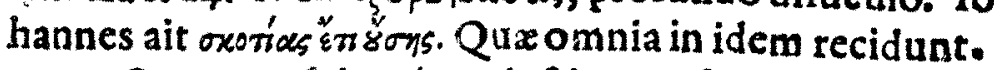

2. Orto jam [ole] placet leetio vetufti codicis, àvaréri:

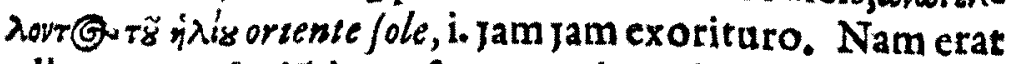
adhuc crepufculú, hoc eft tempus inter lueem \& tenebras medium. Notum aurem ut participium prafens pro pauIo poff futuro fumatur.

14. Novirsime recumbentibus illis undecim apparuit etc. J Hunc locum citat Hieron.lib.2.adverfus Pelagianos;' cap. 6. led paullo aliter. Vide, fi placet.

15. Omni creaturx] id eft, omnibus hominibus.' Vt creaturx nomen ad omnes homines reftringitur, fic Eva vocatur mater omnium viventium, id eft, hominum. Sic etiam carnis vocabulum, quod latius patet, de folis ho.

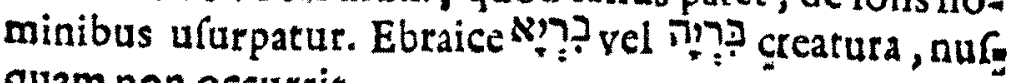
quam non occurrit.

5 Twee bladzıden uit één van de commentaren op het Nieuwe Testament van Johannes Drusius, de Annotationum in totum Jesu Christi Testamentum siue Praetertorum libr decem, 


\title{
I. D R U S I \\ PRETERITOR UM
}

\author{
LIBER TERTIVS.
}

Luce 1.5.

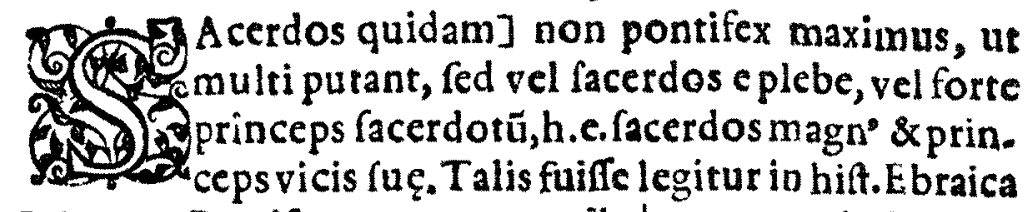

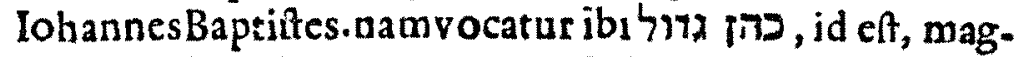
nus facerdos. Sic etiamrocätur Iohannes \& Matthathias halamonxi;qui prxerăt (ita videturjvici lojarib.qux pri. ma erat inter viginti quatuor, e quo \&lolephus fuifréme. moratur, Vt urfit, $\mathrm{n}_{2} \mathrm{~m}$ temerarium el in re tam obfcura \& latente aliquid adfirmare, fi fuit magnus facerdos, videtur ea res impofuiffe patrib. nomine illo põtificem fum. mú intelligentibus, qui etiam aliquădo uta vocatur. Hoc

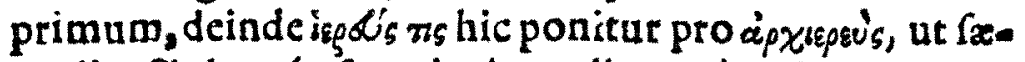
pe alias.Sic izposévn facerdotium, aliquando ufurpatur pro apxesporivy, id eft, fummum lacerdotium. Nota hac do: ctis. Porro Zachariam hunc fuiffe unum ex principibus facerdotum Theodorus adfirmat.' Vide ipfius annotati. ones ultimas verf. 6.ad hunc locum, ln onsnibus mandat is or consititutionibus.

8. In ordine vicis [næ] quam vicem Abia vocat fupra verf. s. Erant autem vices facerdotum viginti quatuor a prophetis prioribus inftitut $x$, hoc eft, à Samuele \& Davide, ut habetur in libro praceptorum magno 2 1 1.3. In priore Machiabæorum mentio vicis Iojarib, qua prima erat in ordine, de qua lolephus fuiffe perhibetur. In Iuchafin

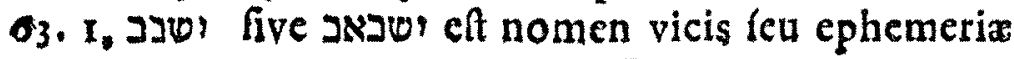

$$
\underline{K} 3
$$

Franeker 1612 Bij Marcus 16 citeert Drusius uit Hieronymus 'In bijna alle handschriften uit de Griekse wereld ontbreekt van dit hootdstuk het slot' 
wie dit doet, houdt de totale wet'. En elders: 'Wie de vrede liefheeft, heeft de schepselen lief, zoals geschreven staat: Gij zult uw naaste liefhebben als uzelf, wat de grote algemene regel is in de wet. Wie echter zijn naaste liefheeft, zondigt tegen hem in niets'.',

Bij deze reeks lapidaire citaten laat Drusius het, toelichting blijft achterwege. Zoveel echter maakt hij duidelijk, dat het tweede lid van het bekende tweeledig gebod ook in oude rabbijnse traditie (Aqiba stierf in 135 n.C., Hillel was actief ca. 20 v.C.) als samenvatting van de gehele wet gehanteerd werd. De analogie maakt Mt. 22 : 39 tot een minder geïsoleerd dictum dan het zou kunnen lijken te zijn indien men het door Drusius geciteerde materiaal niet kende. ${ }^{85}$

Dezelfde functie heeft Drusius' aantekening bij Mt. 6:34: 'Maakt u dan niet bezorgd tegen de dag van morgen, want de dag van morgen zal zijn eigen zorgen hebben; elke dag heeft genoeg aan zijn eigen kwaad'. Drusius schrijft:

“'Zijn eigen kwaad: in het Hebreeuws racato, 'zijn ellende', 'kwelling'. Het is een spreekwoord, dat men in het Hebreeuws aldus zou formuleren: daj lajjom racato, 'voldoende is voor de dag zijn kwaad'. In het boek Uitgelezen Parels, dat ik in een handschrift heb dat helemaal uit Syrië is meegebracht en mij toegezonden is, staat: 'Waarom zult $U$ bedrukt zijn om kwelling die nog niet gekomen is?' dajjah tsara br-5catah, 'kwelling is voldoende op het uur dat ze er is, op haar ure', ${ }^{86}$ uit het hoofdstuk over de duldzaamheid.

In Tanchuma, fol. 29, col. 4, staat: 'Rabbi Eleazar uit Modium zegt: Alwie genoeg heeft om vandaag te eten en zegt: wat moet $\mathrm{k}$ morgen eten?, zie, die schiet tekort in vertrouwen' ${ }^{87}$

De auteur van het boek Musar schrijft $(127,2)$ : 'Rabbi Eliezer de oudere zegt: Een ieder die brood in de mand heeft en zegt: wat moet ik morgen eten?, zie, deze is miqthanne 'mana, in het Grieks zou men zeggen'ex olvgopısthôn, d.w.z. hij behoort tot de kleingelovigen'. ${ }^{88, '}$

Het optreden van rabbi Eliezer de oudere wordt omstreeks 90 n.C. gedateerd, Eleazar uit Modiim stierf omstreeks 135 n.C.: men ziet hoe Drusius bij de raad, bij de dag te leven en niet bezorgd te zijn over moeiten die nog in de toekomst liggen, op goede analogieën weet te wijzen, die zich chronologisch niet al te ver van het Mt.-evangelie verwijderen. Door de woorden 'elke dag heeft genoeg aan zijn eigen kwaad' als spreekwoord te

85 Zie overigens K Berger, Die Gesetzesauslegung Jesu I, Neukirchen 1971, pp 131 - 142, over het verschil tussen de vroegchristelıjke en de rabbınse opvattıng van wat 'de naaste' is in Lev 1918

86 Precies deze zelfde woorden citeert Billerbeck, Kommentar, I, p 441 als parallel bij Mt 634 uit de Babylonische talmud, Berakhot 9b

87 Dezelfde woorden van Eleazar citeert Billerbeck, Kommentar, I, p 421 uit Mekhilta 55b op Exodus 164

88 Dezelfde woorden van Eliezer citeert Billerbeck, Kommentar, I, p 439 uit de Babylonische talmud, Sota $48 \mathrm{~b}$ 
bestempelen, geeft hij er blijk van, rekening te houden met de categorie die men tegenwoordig voorzichtiger, maar vager (en ook niet altijd zonder achteloosheid) een 'traditie' noemt. In dit verband moge worden aangestipt, dat ook reeds Scaliger er een exegetisch programmapunt van maakte, in de evangeliën en het overige Nieuwe Testament die zinnen en wendingen te signaleren die als idiomatische uitdrukkingen en spreekwoordelijke gezegden in de talmud voorkomen. Zo laten bepaalde uitlatingen van Jezus zich verstaan als spreuken geput uit het gewone spraakgebruik van de joden: Christus affert illa ex commun sermone Judaeorum. ${ }^{89}$ Hier heeft men te doen met niet minder dan het (totaal vergeten) praeludium op Bultmanns bestudering van het literaire genre spreekwoord als component in de ontstaansgeschiedenis van de synoptische evangeliën. ${ }^{90}$ Drusius zelf heeft in zijn Proverbıa (Franeker 1590) en in zijn Adagıa Ebraıca ( $\imath$ bıd. 1597) ${ }^{91}$ vele honderden spreekwoorden, o.a. uit het Nieuwe Testament, bijeengebracht en aldus bepaalde relaties tussen de taal en gedachtenwereld van de evangeliën en die van de rabbijnse literatuur zeer aannemelijk gemaakt. Bij het woord van de balk en de splinter in Lc. 6:41 bij voorbeeld noteert hij in zijn Annotationes de uitstekende parallel van rabbi Tarphon (ca. 100 n.C.):

"Rabbi Tarphon (Tryphon noemt Justinus hem) zegt: 'Het verwondert mij, dat er in deze generatie nog iemand is die een ander wil terecht wijzen. Want als hij tegen iemand zegt: Doe de splinter uit uw oog, krijgt hij onmiddellijk te horen: Doe de balk weg van tussen uw tanden'. Uit het boek Musar, hoofdstuk 8, in het begin. (...)", ${ }^{92}$

Dat Scaliger Drusius in deze belangstelling heeft gestimuleerd blijkt uit een Appendix bij Drusius' Adagıa Ebrazca, waarin hij meedeelt een aantal spreekwoorden uit More Nebukhım van Mozes 'de Egyptenaar' te hebben ontvangen van Scaliger.

Als laatste voorbeeld van de wijze waarop Drusius op het Nieuwe Testa-

89 Scaligerana Secunda, ed P des Malzeaux, Amsterdam 1740, pp 521 - 522 Als voorbeeld noemt Scalıger, zeer juist, Mt 2324 'die de mug uitziften, maar de kameel doorzwelgen' (cf Billerbeck ad loc 'Wohl sprichwortliche Redensart') en Mt 917 'Men doet geen nieuwe wijn in oude zakken' Cf W A Beardslee, 'Uses of the proverb in the Synoptic Gospels', Interpretation 24 (1970), pp $61-73$, waar het feit dat bestaande spreekwoorden in de evangelien zijn opgenomen wordt verondersteld

90 R Bultmann, Die Geschichte der synoptischen Tradition, Gottingen 1958 ${ }^{4}$, pp $101-113$ en elders, over Mt 634 op p 111 'Jesus kann sehr wohl gelegentlich ein volkstumliches Sprichwort aufgenommen und auch geandert haben, er kann gewiss auch gelegentlich einen profanen Maschal selbst gepragt haben Moglicherweise sind aber auch profane Spruche erst durch die Gemeinde zu Jesusworten gemacht worden, indem sie sie in den Zusammenhang ihrer Tradition aufnahm' ( $\mathrm{p}$ 105)

91 Beide werken zıjn opgenomen onder de tractaten aan het eind van de Critıcı Sacr 'Elke dag heeft genoeg aan zijn eigen kwaad' wordt besproken in de Proverbıa, Classis I, liber III, xiv

92 Dezelfde woorden van Tarphon citeert Billerbeck, Kommentar I, p 446 uit de Babylonısche talmud, Arakhın 16b 
ment licht wierp diene zijn commentaar bij Lc. 6:7 'De schriftgeleerden en farizeeën letten op hem, of hij op de sabbat een genezing zou verrichten':

"Want op de sabbat was het niet geoorloofd de geneeskunst uit te oefenen. Men mocht zelfs geen speeksel op ogen doen, omdat dat een geneeswijze is. ${ }^{93}$ Tanchuma fol. 5, col. 1 zegt: 'Ook een pleister mochten ze op die dag niet op een wond doen'. ${ }^{94}$ Hetzelfde boek zegt, 30,1: 'Het is verboden een verband aan te leggen op een wond op de sabbat', zie hetgeen volgt. Hier voelt men lust uit te roepen:

$O$ blinde geesten der mensen, en blinde harten. ${ }^{95}$

Ze maken echter een uitzondering voor levensgevaar, d.w.z. wanneer het leven van een zieke op het spel staat. Want dan mochten ze hem medische hulp verlenen. Er staat weer in Tanchuma 8,1: 'Op de sabbat mag men medische hulp verlenen in geval van levensgevaar, zoals bij besnijdenis'. ${ }^{96}$ En 83,4: 'Men mag ook vluchten wegens rovers en een vijandelijk leger'. ${ }^{97}$

Over de inachtneming van de sabbat bestaat er een dialoog van rabbi Aqıba de farızeeer met Turnus of Turannıus Rufus de Romeinse krijgsman, die de ploeg over het tempelgebied heeft laten trekken. ${ }^{98} \mathrm{U}$ zult dat gesprek vinden in Ilmedenu of (als $U$ liever wilt) Jelammedenu, fol. 41, col. 3. Daar zegt hij, om andere dingen nu niet te noemen, dat diegene die doden opwekt met een python, dat niet mag doen op de sabbat, ofschoon het op andere dagen mag. Sla de passage na, zo u wilt'.

Niet alleen slaagt Drusius hier erin, de evangelietekst doeltreffend te illustreren met passages uit rabbijnse bronnen waarin medische verrichtingen op de sabbat in principe worden verboden. Tevens weet hij in het kort een representatief beeld te tekenen van de casuistiek die door dit verbod in de praktijk werd uitgelokt. De commentaar geeft reeds in nuce hetzelfde wat, met veel meer documentatie, Billerbeck biedt bij de parallelplaats Mt. 12:10. Met recht kan Drusius worden beschouwd als de voorloper van John Lightfoot van Cambridge, wiens waardevolle Horae hebratcae et talmudrcae van 1658 tot 1678 verschenen, en van Billerbeck, wiens Kommentar zum Neuen Testament aus Talmud und Midrasch vanaf 1922 uitkwam. Zonder dat er hier nader op kan worden ingegaan, moet trouwens worden opgemerkt, dat ook Coccejus in zijn uitgebreide, een groot deel van het Nieuwe Testament bestrijkende commentaren, veelvuldig een

93 Billerbeck, Kommentar I, p 628 citeert voor deze opvattung de Palestıjnse talmud, Sjabbath 14, 14d, 17 en andere bronnen, waaronder ook Tanchuma

94 Cf Billerbeck, Kommentar I, p 628

95 Drusius citeert hier Lucretius II 14, maar vervangt miseras door caecas Lucretius vervolgt 'In welk een duisternıs en hoevele gevaren verloopt dıt beetje tıjd dat uw leven maar is'

96 Billerbeck, Kommentar I, p 624

97 Ook Billerbeck, Kommentar I, p 626 citeert deze opvatting uit Tanchuma

98 Zie voor deze legende E Schurer, Geschichte des Judischen Volkes im Zettalter Jesu Christı I, Leipzig $1901^{3 \text { en } 4}$, pp 692693 
nuttıg gebruik van de talmud maakt en dat met name de Gronıngse coccejaan Joh Braun, hoogleraar theologie en Hebreeuws van 1680 tot 1708, in zijn Commentarius in Epistolam ad Hebraeos (Amstaelodamı 1705) veel waardevolle gegevens uit de rabbijnse literatuur citeert

De tweede mijn van instructief vergelıjkingsmateriaal die in de $17 \mathrm{de}$ eeuw werd ontgonnen wordt gevormd door de oude vertalıngen Hun belang is tweeerle1 Enerzijds laten zlj vaak tot in fijne bijzonderheden zien, welke betekenissen en betekenisnuances in de oudheid aan de woorden en zinnen van het Nieuwe Testament werden toegekend Anderzijds leert vergelıjkıng van oude vertalıngen, dat in vroege stadıa van de tekstoverleverıng het Nieuwe Testament niet steeds in één onveranderlıjke vorm voorhanden geweest is in de vertalingen is de tekst soms korter, elders weer langer dan de Grıekse tekst, terwıl dikwıls een van het Grieks afwıkende lezıng geboden wordt Zulke verschıllen kunnen er in bepaalde gevallen een aanwızıng van zıjn, dat oudtıjds een andere Griekse tekst van het Nieuwe Testament heeft gecirculeerd dan welke de 17de-eeuwse geleerden ter beschıkkıng stond Vergelıjkıng van de vertalıngen kan de exegeet dus behoeden voor ongerechtvaardigd optımısme inzake de authenticiteit van de gangbare, door de meesten aanvaarde tekstvorm Onderzoek van de vertalıngen maant tot voorzıchtıgheid bij het bepalen van wat precies de door evangelisten en apostelen gebruikte woorden zijn geweest en soms tot argwaan jegens de algemeen voor juist uitgegeven tekst Dit type onderzoek is op nieuwtestamentisch gebied geentameerd door Valla en Erasmus, wier Annotationes in wezen niets anders zıjn dan de observatıes die zıj deden bij het vergelıjken van de toenmaals gebruıkelıke bijbeltekst, de Latıjnse vulgata, met de (of liever een) Griekse tekst In het 17 de-eeuwse protestantisme was de vulgata echter als grondslag van serıeus bıjbelonderzoek intussen vervangen door Hebreeuwse en Griekse uitgaven, maar wat het Nieuwe Testament betreft werd nu de Griekse tekst het object van vergelıjkıng, vergelıjkıng met oude en ook wel nieuwe vertalingen die interesse was nog lang niet gedoofd en zou alleen maar intenser worden

De grote specialist op dit terrein is in de 17 de eeuw geweest de Leidse orientalıst Louıs de Dieu Hij publiceerde zıjn Anımadversiones op de evangelıen in 1631, die op Acta in 1634, die op de paulınısche en katholieke brieven verschenen in $1646{ }^{99}$ Hierin vergeleek hij systematısch de Griekse tekst met o a de oude Syrısche, Arabische en Ethıpische vertalingen, met de oude en diverse nieuwe Latıjnse versies en Matthaeus ook met twee recente Hebreeuwse, uit de vulgata vervaardigde vertalıngen

Hier volgen enige specimina van de aantekenıngen van De Dieu

In het Gethsemane-verhaal van Mc 14 zegt Jezus, na de discipelen voor de derde keer slapend te hebben aangetroffen Apecher Elthen hè hôra, wat gewoonlık wordt vertaald met 'Het is genoeg De ure is gekomen' Hier-

99 Het makkelıkst raadpleegt men deze werken in de uitgave van De Dieu's verzamelde werken, die onder de titel Critıca sacra, sive Antmadversiones in loca quaedam difficiliora Veteris et Novi Testamenti verscheen te Amsterdam in 1693 


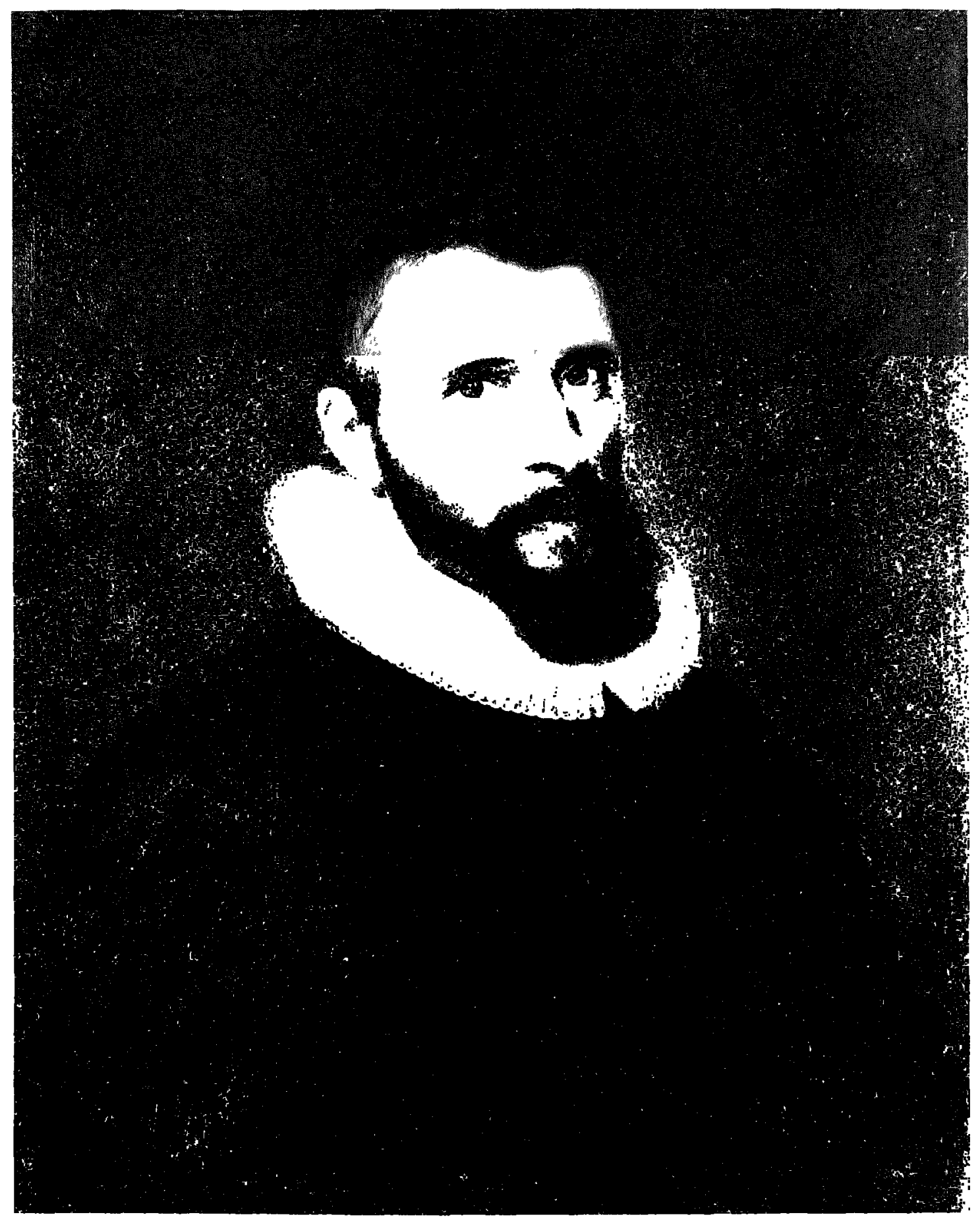

6. Louis de Dieu, ca. 1640. 
bij merkt De Dieu op, dat de Syrische vertaling heeft: 'Het einde is daar, en de ure is gekomen' en dat de Arabische vertaling heeft: 'Het einde is reeds aangebroken, en de ure is gekomen'. De Dieu vervolgt:

"Men lette er dus op, hoe de Syrische en de Arabische vertaling het Griekse apechei interpreteren, namelijk zo, dat het hetzelfde is als wanneer wij in het Nederlands zeggen 'het heeft het wech'. Dit heeft volkomen dezelfde gevoelswaarde, namelijk: er rest tussen ons niets meer te doen, onze zaak is ten einde, zie, de Zoon des mensen wordt overgeleverd, enz.

Apechein wordt dikwijls gebruikt voor iemand die ontvangen heeft wat hem toekwam en die niets meer te eisen heeft. Suidas zegt: 'Apechô staat voor: ik heb het mijne ontvangen. Bij voorbeeld: wij hebben de dank ontvangen, indien namelijk een blijk van dank verschuldigd was. - En voorts op een inscriptie: Het verschuldigde dat $\mathrm{u}$, Asclepius, toekwam van een eenvoudige vrouw, hebt gij ontvangen. - En: Ik heb de betaling voor het voeden en grootbrengen van het kind ontvangen'.

Zo ook op deze plaats: Christus die op het punt staat zijn omgang met de discipelen te beëindigen, zegt met een onpersoonlijke uitdrukking: Apechei, d.w.z. onze zaak heeft haar einde bereikt, alwat aan onze omgang verschuldigd was, is eraan gegeven. Slapen jullie maar voort en rust. Ik ga weg en word overgeleverd.

De vulgata en Beza vertalen: 'Het is genoeg' ${ }^{100}$ (sufficit). Ik zou liever vertalen: 'Het is afgelopen' (peractum est). Dit heeft de Syrische vertaling uitgedrukt met: 'Het einde is daar'.',

Hier ziet men, hoe De Dieu zich door de Syrische en Arabische vertalingen laat stimuleren om aan het inderdaad lastige apechei een aanvaardbare interpretatie te geven die ook door het Griekse taalgebruik reeds werd aanbevolen en die een enigszins andere vertaling dan het gebruikelijke 'Het is genoeg' tot gevolg heeft.

$\mathrm{Bij}$ de woorden van de twaalfjarige Jezus 'Wisten jullie niet dat ik in de dingen mijns vaders moest zijn?' (Lc. 2:49) wijst De Dieu erop, dat de Syrische vertaling deze weergeeft met 'Weten jullie niet dat ik in het huis mijns vaders moet zijn?'

"Het verdient de aandacht, dat de Syrische vertaling onder 'de dingen des vaders' niet de zaken van de vader, maar het huis van de vader, d.w.z. de tempel heeft verstaan. Zie hierover de geleerde verhandeling ${ }^{101}$ van Nic. Fuller, Miscellanea sacra IV, hoofdstuk 17. De interpretatie van de Arabische vertaling is dubbelzinnig: 'Het is noodzakelijk dat ik ben in hetgeen mijns vaders is".

De wending 'de dingen van de vader' is in het Grieks inderdaad voor tweeërlei uitleg vatbaar: 'het werk, de zaak, het beleid van de vader' en

100 Zo korte tijd later ook de Statenvertaling.

101 Fullers Miscellanea Sacra vormen het eerste van de aan de Critici Sacri toegevoegde tractaten. 
'het huis van de vader'. In veel moderne vertalingen wordt kortweg voor de weergave 'het huls' gekozen. Terecht heeft De Dieu de mogelijkheid van deze tweede betekenis met een beroep op de Syrische vertaling in het licht gesteld. Overigens is niet minder van belang, dat hij erop wijst dat de Arabische vertaling de ambiguiteit van het Grieks bewaart; er is namelijk reden om aan te nemen dat Lucas zich niet geheel zonder opzet deze dubbelzinnigheid heeft veroorloofd.

Tal van De Dieu's opmerkingen hebben het karakter van in extenso geformuleerde tekstkritische aantekeningen` zo bij voorbeeld bij Mt. 27:35. In de 17 de eeuw werd in dit vers na ' $\mathrm{Zij}$ verdeelden zijn kleren door het lot te werpen' nog gelezen 'opdat vervuld werd hetgeen gesproken is door de profeet: ze hebben mijn kleren onder elkaar verdeeld en over mijn mantel hebben zy het lot geworpen'. Dit laatste tekstgedeelte, dat o.a. in de Statenvertaling is opgenomen, geeft De Dieu aanleiding tot de volgende notitie.

"Erasmus zegt, dat dit getuigenıs van de profeet in de meeste Griekse handschriften ontbreekt, en dat Hieronymus het geen enkele keer vermeldt. Volgens Beza komt de passage in geen enkel van de zeer oude handschriften voor. Ook de makers van de Syrische en Ethiopische vertalıngen hebben de passage niet gekend. Want hoewel zij voorkomt in de Syrısche uitgave van Kothen, ${ }^{102}$ weet $1 \mathrm{k}$ niet op grond waarvan dit gebeurd is, tenzij bij geval uitsluitend op grond van de Plantın-uitgave in 16-mo die in Hebreeuwse letters gedrukt is. ${ }^{103}$ Daarentegen is de passage volkomen onbekend in het handschrift benut door Tremellius, ${ }^{104}$ de Weense uitgave, ${ }^{105}$ de editio Regia (=de Antwerpse Polyglot) en de Parijse editie. ${ }^{106}$ In de vulgata echter, en in de Arabische vertaling en in de beide uitgaven van het Mt.-evangelıe in het Hebreeuws ${ }^{107}$ wordt de passage aangetroffen',

Uit een aantekening als de juist geciteerde valt op te maken, hoe zorgvuldig De Dieu zich documenteerde. Tot zijn documentatie behoorde ook het Syrische handschrift dat hij omstreeks 1630 van James Ussher te leen

102 Bedoeld is de uitgave bezorgd door de Wittenberger Martın Trost, voorzien van Latıjnse vertaling en varianten uit vijf gedrukte editıes, verschenen te Kothen in Anhalt, 1621

103 Antwerpen 1575, inderdaad in 16-mo (niet in 24-mo, zoals Scrivener zegt) Zie Shorttutle Catalogue of Books Printed in the Netherlands and Belgium from 1470 to 1600 now in the Brtish Museum, London 1965, p 32

104 Een Heidelbergs handschrift, gebrulkt in zyn uitgave van Genève 1569 (Darlow and Moule nr 1421) Zie C R Gregory, Texikntık des $N T$, Leipzig 1900, p 497

105 De editio princeps van de Pesjitta van Albert Widmanstadt, Wenen 1555 Gregory, Textkrtik, pp $495-497$

106 De editıe door Guy le Fèvre, Parıjs 1584, in ongevocalıseerd Hebreeuws schrift

107 Gedoeld wordt op de utgave van de Hebreeuwse versie van Mt door Sjem Tob ben Sjaprut (ca 1385) verzorgd door Seb Munster (Bazel 1537) en op die verzorgd door Jehan du Tillet met Latıjnse vertalıng door J Mercerus (Parıs 1555), Darlow and Moule 5088 en 5096 
had gekregen en waaruit hij in zijn Animadversiones bij Joh. 7:53 de Syrische editio princeps van de pericoop over de overspelige vrouw (7:53 - 8:11) publiceerde. ${ }^{108}$

De derde belangrijke bron van literair materiaal waarmee het Nieuwe Testament in de 17de eeuw op grote schaal werd vergeleken werd gevormd door de exegetische literatuur van Griekse en Latijnse kerkvaders. Uiteraard was de patristische literatuur de eeuwen door een voornaam richtsnoer voor de interpretatie van de bijbel geweest. Met het theologisch gefundeerde gezag van de patristische traditie in exegetische kwesties had evenwel de Reformatie resoluut afgerekend. Erasmus had een middenpositie ingenomen: hij had de vaders op pragmatische, niet theologische gronden gerangschikt naar hun belang en waarde, de exegese van de voornaamsten intensief benut, maar zich tegenover elke exegese een eigen kritisch oordeel voorbehouden, soms waarderend, soms afwijzend. De theologische afstand die de Reformatie tijdelijk met nogal wat nadruk tot de vaders nam, stelde op den duur gereformeerde exegeten weer in staat, de vaders vrij tegemoet te treden en hen onbevangen op hun waarde voor de exegese te beoordelen. De patres spraken voor hen niet meer met vanzelfsprekend theologisch gezag en de geldigheid van exegetische interpretaties was voortaan onderworpen aan het oordeel van de moderne exegeet. Maar deze omwenteling in de gezagsverhoudingen betekende allerminst de ondergang van de belangstelling voor de patres bij de gereformeerden. Het is integendeel verbluffend, hoe goed verscheidene gereformeerde exegeten van de $17 \mathrm{de}$ eeuw in de patres thuis zijn geweest.

Toetsing van interpretaties van antieke en middeleeuwse christelijke schrijvers vormt vooral van Daniël Heinsius' Exercıtatıones sacrae een belangrijke component. 'Niets moet geletterden liever zijn', aldus Heinsius, 'dan de toetsing en lezing der gewijde vaderen'. ${ }^{109}$

Geregeld wijst Heinsius de uitleg van de patres onbeschroomd van de hand. Bij Lc. 12:10 keurt hij de interpretaties van Job Monachus, Augustinus, Fulgentius, Ambrosius, Hiëronymus en de scholastici af en hekelt hij de wispelturigheid van Augustinus die in vijf verschillende werken minstens vijf verschillende interpretaties van dezelfde plaats gegeven blijkt te hebben. Van Augustinus' toelichting bij Rom. 14:5 zegt Heinsius: 'Zulke uitleggingen laten we graag aan de oudheid over'.

Herhaaldelijk geeft Heinsius uitleggingen van patristische auteurs aan zijn lezers ter overweging zonder er zelf een keuze tussen te maken of oordeel over te vellen. Ook gebruikt hij de kerkvaders om uit hun bijbelcitaten aan te tonen, dat bepaalde passages oudtijds in sterk variërende tekstvormen zijn overgeleverd, althans geciteerd. Zo vermeldt Heinsius de verschillende lezingen die Lc. 12:49b in de citaten bij Origenes, Macarius, Hieronymus, Chrysostomus en Cyrillus van Alexandrie heeft.

108 Zie F A H Scrivener, A Plain Introduction to the Critccism of the New Testament, Cambridge $1883^{3}$, pp $315-316$ Gregory, Textkrttk, pp 498, 526 B M Metzger, The Early Verstons of the New Testament, Oxford 1977, p 67 noot 1

109 Exercitationes sacrae, p 350 
ment licht wierp diene zijn commentaar bij Lc. 6:7 'De schriftgeleerden en farizeeën letten op hem, of hij op de sabbat een genezing zou verrichten':

"Want op de sabbat was het niet geoorloofd de geneeskunst uit te oefenen. Men mocht zelfs geen speeksel op ogen doen, omdat dat een geneeswijze is. ${ }^{93}$ Tanchuma fol. 5, col. 1 zegt: 'Ook een pleister mochten ze op die dag niet op een wond doen'. ${ }^{94}$ Hetzelfde boek zegt, 30,1: 'Het is verboden een verband aan te leggen op een wond op de sabbat', zie hetgeen volgt. Hier voelt men lust uit te roepen:

\section{$O$ blinde geesten der mensen, en blinde harten ${ }^{95}$}

Ze maken echter een uitzondering voor levensgevaar, d.w.z. wanneer het leven van een zieke op het spel staat. Want dan mochten ze hem medische hulp verlenen. Er staat weer in Tanchuma 8,1: 'Op de sabbat mag men medische hulp verlenen in geval van levensgevaar, zoals bij besnijdenis'. ${ }^{96}$ En 83,4: 'Men mag ook vluchten wegens rovers en een vijandelijk leger'. ${ }^{97}$

Over de inachtneming van de sabbat bestaat er een dialoog van rabbi Aqiba de farizeeèr met Turnus of Turannius Rufus de Romeinse krijgsman, die de ploeg over het tempelgebied heeft laten trekken. ${ }^{98} \mathrm{U}$ zult dat gesprek vinden in Ilmedenu of (als $U$ liever wilt) Jelammedenu, fol. 41, col. 3. Daar zegt hij, om andere dingen nu niet te noemen, dat diegene die doden opwekt met een python, dat niet mag doen op de sabbat, ofschoon het op andere dagen mag. Sla de passage na, zo u wilt'”.

Niet alleen slaagt Drusius hier erin, de evangelietekst doeltreffend te illustreren met passages uit rabbijnse bronnen waarin medische verrichtingen op de sabbat in principe worden verboden. Tevens weet hij in het kort een representatief beeld te tekenen van de casuïstiek die door dit verbod in de praktijk werd uitgelokt. De commentaar geeft reeds in nuce hetzelfde wat, met veel meer documentatie, Billerbeck biedt bij de parallelplaats Mt. 12:10. Met recht kan Drusius worden beschouwd als de voorloper van John Lightfoot van Cambridge, wiens waardevolle Horae hebratcae et talmudrcae van 1658 tot 1678 verschenen, en van Billerbeck, wiens Kommentar zum Neuen Testament aus Talmud und Midrasch vanaf 1922 uitkwam. Zonder dat er hier nader op kan worden ingegaan, moet trouwens worden opgemerkt, dat ook Coccejus in zijn uitgebreide, een groot deel van het Nieuwe Testament bestrijkende commentaren, veelvuldig een

93 Billerbeck, Kommentar I, p 628 citeert voor deze opvattung de Palestıjnse talmud, Sjabbath 14, 14d, 17 en andere bronnen, waaronder ook Tanchuma

94 Cf Billerbeck, Kommentar I, p 628

95 Drusius citeert hier Lucretius II 14, maar vervangt miseras door caecas Lucretius vervolgt 'In welk een duisternis en hoevele gevaren verloopt dit beetje tıjd dat uw leven maar is'

96 Billerbeck, Kommentar I, p 624

97 Ook Billerbeck, Kommentar I, p 626 citeert deze opvatting uit Tanchuma

98 Z1e voor deze legende E Schurer, Geschichte des Judischen Volkes im Zettalter Jesu Christı I, Lelpzig $1901^{3 \text { en } 4}$, pp $692-693$ 
nuttig gebruik van de talmud maakt en dat met name de Groningse coccejaan Joh. Braun, hoogleraar theologie en Hebreeuws van 1680 tot 1708, in zijn Commentarius in Epistolam ad Hebraeos (Amstaelodami 1705) veel waardevolle gegevens uit de rabbijnse literatuur citeert.

De tweede mijn van instructief vergelijkingsmateriaal die in de $17 \mathrm{de}$ eeuw werd ontgonnen wordt gevormd door de oude vertalingen. Hun belang is tweeërlei. Enerzijds laten zij vaak tot in fijne bijzonderheden zien, welke betekenissen en betekenisnuances in de oudheid aan de woorden en zinnen van het Nieuwe Testament werden toegekend. Anderzijds leert vergelijking van oude vertalingen, dat in vroege stadia van de tekstoverlevering het Nieuwe Testament niet steeds in één onveranderlijke vorm voorhanden geweest is: in de vertalingen is de tekst soms korter, elders weer langer dan de Griekse tekst, terwijl dikwijls een van het Grieks afwijkende lezing geboden wordt. Zulke verschillen kunnen er in bepaalde gevallen een aanwijzing van zijn, dat oudtijds een andere Griekse tekst van het Nieuwe Testament heeft gecirculeerd dan welke de $17 \mathrm{de}$-eeuwse geleerden ter beschikking stond. Vergelijking van de vertalingen kan de exegeet dus behoeden voor ongerechtvaardigd optimisme inzake de authenticiteit van de gangbare, door de meesten aanvaarde tekstvorm. Onderzoek van de vertalingen maant tot voorzichtigheid bij het bepalen van wat precies de door evangelisten en apostelen gebruikte woorden zijn geweest en soms tot argwaan jegens de algemeen voor juist uitgegeven tekst. Dit type onderzoek is op nieuwtestamentisch gebied geëntameerd door Valla en Erasmus, wier Annotationes in wezen niets anders zijn dan de observaties die zij deden bij het vergelijken van de toenmaals gebruikelijke bijbeltekst, de Latijnse vulgata, met de (of liever: een) Griekse tekst. In het 17 de-eeuwse protestantisme was de vulgata echter als grondslag van serieus bijbelonderzoek intussen vervangen door Hebreeuwse en Griekse uitgaven, maar wat het Nieuwe Testament betreft werd nu de Griekse tekst het object van vergelijking, vergelijking met oude en ook wel nieuwe vertalingen: die interesse was nog lang niet gedoofd en zou alleen maar intenser worden.

De grote specialist op dit terrein is in de 17 de eeuw geweest de Leidse oriëntalist Louis de Dieu. Hij publiceerde zijn Animadversiones op de evangeliën in 1631, die op Acta in 1634; die op de paulinische en katholieke brieven verschenen in $1646 .{ }^{99}$ Hierin vergeleek hij systematisch de Griekse tekst met o.a. de oude Syrische, Arabische en Ethiopische vertalingen, met de oude en diverse nieuwe Latijnse versies en Matthaeus ook met twee recente Hebreeuwse, uit de vulgata vervaardigde vertalingen.

Hier volgen enige specimina van de aantekeningen van De Dieu.

In het Gethsemane-verhaal van Mc. 14 zegt Jezus, na de discipelen voor de derde keer slapend te hebben aangetroffen: Apechei. Elthen hè hôra, wat gewoonlijk wordt vertaald met: 'Het is genoeg. De ure is gekomen'. Hier-

99 Het makkelijkst raadpleegt men deze werken in de uitgave van De Dieu's verzamelde werken, die onder de titel Critica sacra, sive Animadversiones in loca quaedam difficiliora Veteris et Novi Testamenti verscheen te Amsterdam in 1693. 


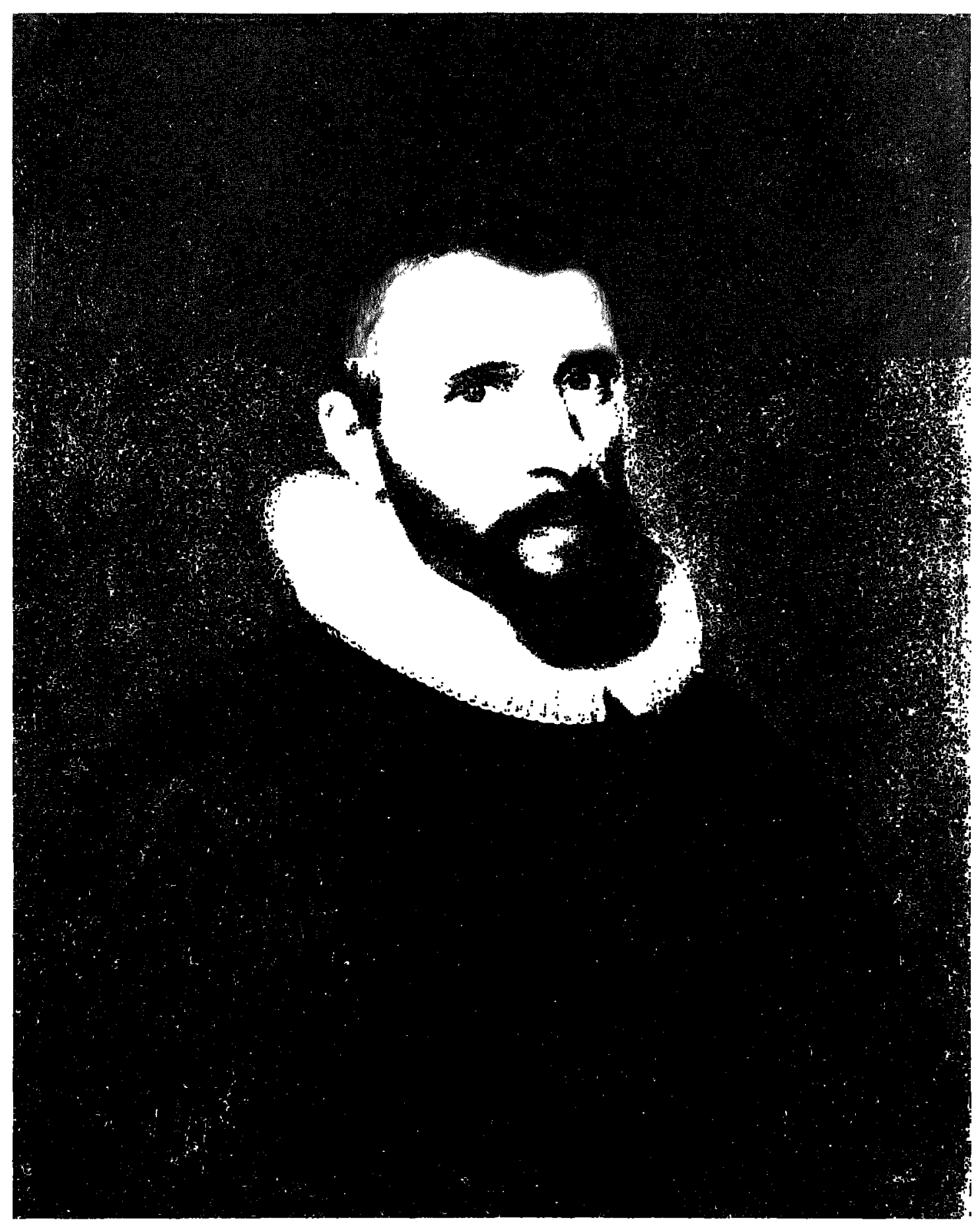

6. Louis de Dieu, ca. 1640. 
bij merkt De Dieu op, dat de Syrische vertaling heeft: 'Het einde is daar, en de ure is gekomen' en dat de Arabische vertaling heeft: 'Het einde is reeds aangebroken, en de ure is gekomen'. De Dieu vervolgt:

"Men lette er dus op, hoe de Syrische en de Arabische vertaling het Griekse apechei interpreteren, namelijk zo, dat het hetzelfde is als wanneer wij in het Nederlands zeggen 'het heeft het wech'. Dit heeft volkomen dezelfde gevoelswaarde, namelijk: er rest tussen ons niets meer te doen, onze zaak is ten einde, zie, de Zoon des mensen wordt overgeleverd, enz.

Apechein wordt dikwijls gebruikt voor iemand die ontvangen heeft wat hem toekwam en die niets meer te eisen heeft. Suidas zegt: 'Apechô staat voor: ik heb het mijne ontvangen. Bij voorbeeld: wij hebben de dank ontvangen, indien namelijk een blijk van dank verschuldigd was. - En voorts op een inscriptie: Het verschuldigde dat $u$, Asclepius, toekwam van een eenvoudige vrouw, hebt gij ontvangen. - En: Ik heb de betaling voor het voeden en grootbrengen van het kind ontvangen'.

Zo ook op deze plaats: Christus die op het punt staat zijn omgang met de discipelen te beëindigen, zegt met een onpersoonlijke uitdrukking: Apechei, d.w.z. onze zaak heeft haar einde bereikt, alwat aan onze omgang verschuldigd was, is eraan gegeven. Slapen jullie maar voort en rust. Ik ga weg en word overgeleverd.

De vulgata en Beza vertalen: 'Het is genoeg' ${ }^{100}$ (sufficit). Ik zou liever vertalen: 'Het is afgelopen' (peractum est). Dit heeft de Syrische vertaling uitgedrukt met: 'Het einde is daar'."

Hier ziet men, hoe De Dieu zich door de Syrische en Arabische vertalingen laat stimuleren om aan het inderdaad lastige apechei een aanvaardbare interpretatie te geven die ook door het Griekse taalgebruik reeds werd aanbevolen en die een enigszins andere vertaling dan het gebruikelijke 'Het is genoeg' tot gevolg heeft.

Bij de woorden van de twaalfjarige Jezus 'Wisten jullie niet dat ik in de dingen mijns vaders moest zijn?' (Lc. 2:49) wijst De Dieu erop, dat de Syrische vertaling deze weergeeft met 'Weten jullie niet dat ik in het huis mijns vaders moet zijn?'

"Het verdient de aandacht, dat de Syrische vertaling onder 'de dingen des vaders' niet de zaken van de vader, maar het huis van de vader, d.w.z. de tempel heeft verstaan. Zie hierover de geleerde verhandeling ${ }^{101}$ van Nic. Fuller, Miscellanea sacra IV, hoofdstuk 17. De interpretatie van de Arabische vertaling is dubbelzinnig: 'Het is noodzakelijk dat ik ben in hetgeen mijns vaders is".

De wending 'de dingen van de vader' is in het Grieks inderdaad voor tweeërlei uitleg vatbaar: 'het werk, de zaak, het beleid van de vader' en

100 Zo korte tijd later ook de Statenvertaling.

101 Fullers Miscellanea Sacra vormen het eerste van de aan de Critici Sacri toegevoegde tractaten. 
'het huis van de vader' In veel moderne vertalingen wordt kortweg voor de weergave 'het huis' gekozen Terecht heeft De Dieu de mogelijkheid van deze tweede betekenis met een beroep op de Syrısche vertaling in het licht gesteld Overigens is niet minder van belang, dat hij erop wijst dat de Arabische vertaling de ambiguiteit van het Grieks bewaart, er is namelijk reden om aan te nemen dat Lucas zich niet geheel zonder opzet deze dubbelzinnigheid heeft veroorloofd

Tal van De Dieu's opmerkıngen hebben het karakter van in extenso geformuleerde tekstkritısche aantekeningen zo bij voorbeeld bij Mt 2735 In de 17 de eeuw werd in dit vers na ' $Z_{1 j}$ verdeelden zıjn kleren door het lot te werpen' nog gelezen 'opdat vervuld werd hetgeen gesproken is door de profeet ze hebben mijn kleren onder elkaar verdeeld en over mijn mantel hebben $\mathrm{zl}$ jet lot geworpen' Dit laatste tekstgedeelte, dat o a in de Statenvertalıng is opgenomen, geeft De Dieu aanleıdıng tot de volgende notitie

"Erasmus zegt, dat dit getuigenis van de profeet in de meeste Griekse handschriften ontbreekt, en dat Hieronymus het geen enkele keer vermeldt Volgens Beza komt de passage in geen enkel van de zeer oude handschriften voor Ook de makers van de Syrische en Ethiopische vertalıngen hebben de passage niet gekend Want hoewel zij voorkomt in de Syrische uitgave van Kothen, ${ }^{102}$ weet $1 \mathrm{k}$ niet op grond waarvan dit gebeurd is, tenzij bij geval uitsluitend op grond van de Plantijn-uitgave in 16-mo die in Hebreeuwse letters gedrukt is ${ }^{103}$ Daarentegen is de passage volkomen onbekend in het handschrift benut door Tremellius, ${ }^{104}$ de Weense uitgave, ${ }^{105}$ de editio Regia (=de Antwerpse Polyglot) en de Parijse editıe ${ }^{106}$ In de vulgata echter, en in de Arabische vertaling en in de beıde uitgaven van het Mt -evangelie in het Hebreeuws ${ }^{107}$ wordt de passage aangetroffen",

Uit een aantekening als de juist geciteerde valt op te maken, hoe zorgvuldıg De Dieu zıch documenteerde Tot zıjn documentatie behoorde ook het Syrısche handschrift dat hyj omstreeks 1630 van James Ussher te leen

102 Bedoeld is de utgave bezorgd door de Wittenberger Martın Trost, voorzien van Latıjnse vertalıng en varıanten uit vif gedrukte editıes, verschenen te Kothen in Anhalt, 1621

103 Antwerpen 1575, inderdaad in 16-mo (niet in 24-mo, zoals Scrivener zegt) Zie Shorttutle Catalogue of Books Prtnted in the Netherlands and Belgum from 1470 to 1600 now in the Brttush Museum, London 1965, p 32

104 Een Heidelbergs handschrift, gebruıkt in zyn uitgave van Genève 1569 (Darlow and Moule nr 1421) Zie C R Gregory, Textkrttk des NT, Leipzig 1900, p 497

105 De editio princeps van de Pesjitta van Albert Widmanstadt, Wenen 1555 Gregory, Textkritık, pp $495-497$

106 De edıtıe door Guy le Fèvre, Parıjs 1584, in ongevocalıseerd Hebreeuws schrıft

107 Gedoeld wordt op de uitgave van de Hebreeuwse versie van Mt door Sjem Tob ben Sjaprut (ca 1385) verzorgd door Seb Munster (Bazel 1537) en op die verzorgd door Jehan du Tillet met Latıjnse vertalıng door J Mercerus (Parıs 1555), Darlow and Moule 5088 en 5096 
had gekregen en waaruit hij in zijn Animadversiones bij Joh. 7:53 de Syrische editio princeps van de pericoop over de overspelige vrouw (7:53 - 8:11) publiceerde. ${ }^{108}$

De derde belangrijke bron van literair materiaal waarmee het Nieuwe Testament in de 17 de eeuw op grote schaal werd vergeleken werd gevormd door de exegetische literatuur van Griekse en Latijnse kerkvaders. Uiteraard was de patristische literatuur de eeuwen door een voornaam richtsnoer voor de interpretatie van de bijbel geweest. Met het theologisch gefundeerde gezag van de patristische traditie in exegetische kwesties had evenwel de Reformatie resoluut afgerekend. Erasmus had een middenpositie ingenomen: hij had de vaders op pragmatische, niet theologische gronden gerangschikt naar hun belang en waarde, de exegese van de voornaamsten intensief benut, maar zich tegenover elke exegese een eigen kritisch oordeel voorbehouden, soms waarderend, soms afwijzend. De theologische afstand die de Reformatie tijdelijk met nogal wat nadruk tot de vaders nam, stelde op den duur gereformeerde exegeten weer in staat, de vaders vrij tegemoet te treden en hen onbevangen op hun waarde voor de exegese te beoordelen. De patres spraken voor hen niet meer met vanzelfsprekend theologisch gezag en de geldigheid van exegetische interpretaties was voortaan onderworpen aan het oordeel van de moderne exegeet. Maar deze omwenteling in de gezagsverhoudingen betekende allerminst de ondergang van de belangstelling voor de patres bij de gereformeerden. Het is integendeel verbluffend, hoe goed verscheidene gereformeerde exegeten van de 17 de eeuw in de patres thuis zijn geweest.

Toetsing van interpretaties van antieke en middeleeuwse christelijke schrijvers vormt vooral van Daniël Heinsius' Exercitationes sacrae een belangrijke component. 'Niets moet geletterden liever zijn', aldus Heinsius, 'dan de toetsing en lezing der gewijde vaderen'. ${ }^{109}$

Geregeld wijst Heinsius de uitleg van de patres onbeschroomd van de hand. Bij Lc. 12:10 keurt hij de interpretaties van Job Monachus, Augustinus, Fulgentius, Ambrosius, Hiëronymus en de scholastici af en hekelt hij de wispelturigheid van Augustinus die in vijf verschillende werken minstens vijf verschillende interpretaties van dezelfde plaats gegeven blijkt te hebben. Van Augustinus' toelichting bij Rom. 14:5 zegt Heinsius: 'Zulke uitleggingen laten we graag aan de oudheid over'.

Herhaaldelijk geeft Heinsius uitleggingen van patristische auteurs aan zijn lezers ter overweging zonder er zelf een keuze tussen te maken of oordeel over te vellen. Ook gebruikt hij de kerkvaders om uit hun bijbelcitaten aan te tonen, dat bepaalde passages oudtijds in sterk variërende tekstvormen zijn overgeleverd, althans geciteerd. Zo vermeldt Heinsius de verschillende lezingen die Lc. 12:49b in de citaten bij Origenes, Macarius, Hiëronymus, Chrysostomus en Cyrillus van Alexandrië heeft.

108 Zie F. A. H. Scrivener, A Plain Introduction to the Criticism of the New Testament, Cambridge $1883^{3}$, pp. 315 - 316. Gregory, Textkritik, pp. 498, 526. B. M. Metzger, The Early Versions of the New Testament, Oxford 1977, p. 67 noot 1.

109 Exercitationes sacrae, p. 350. 


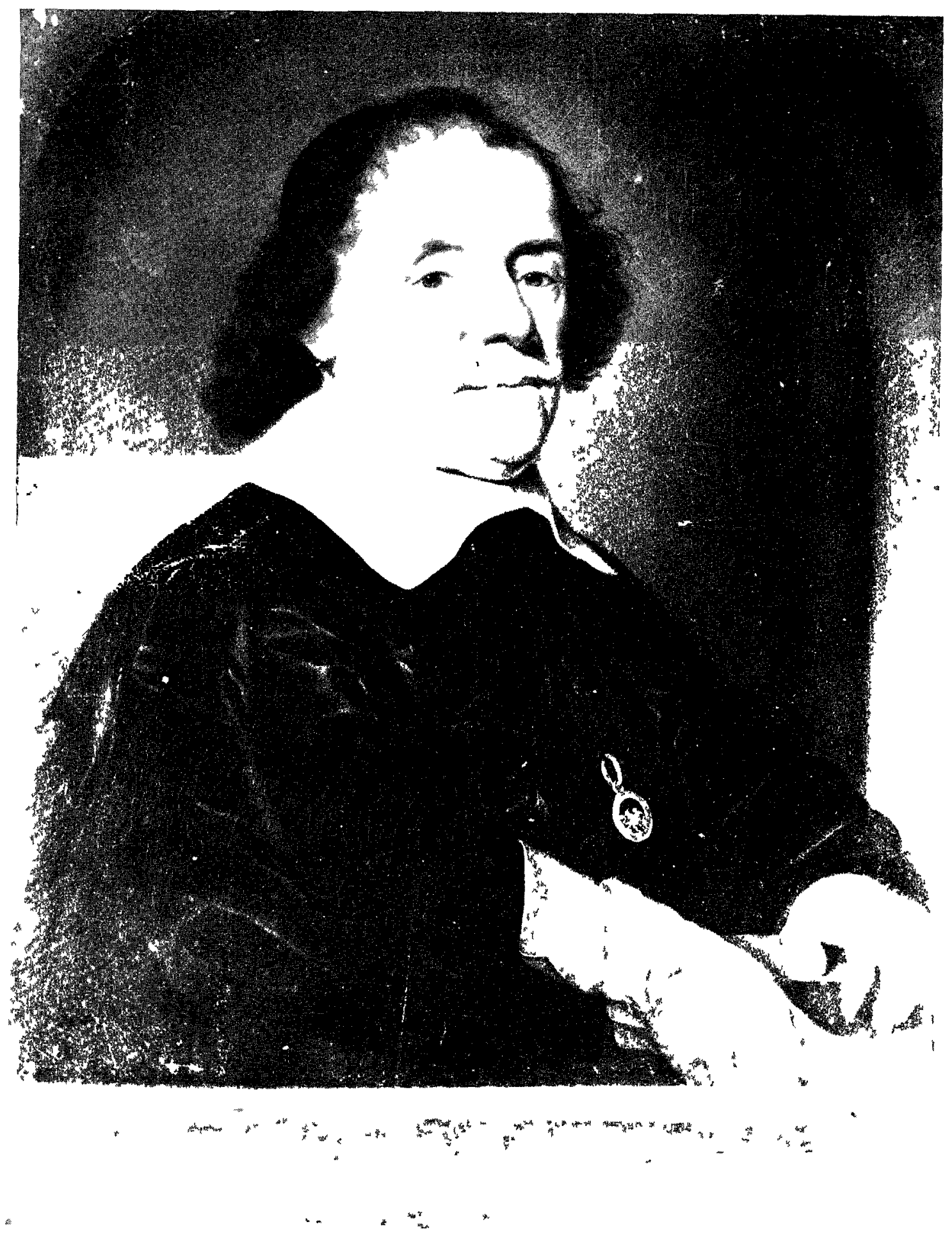

7 Daniel Heinsius naar een schildery uit 1645 
In menig geval tenslotte put Heinsius uit exegeten van de Griekse en Latijnse kerk interpretaties die hem juist voorkomen en die hun waarde inderdaad hebben behouden. Een goed voorbeeld vindt men in zijn commentaar op Mc. 14:72. In dit vers wordt het verhaal van Petrus' verloochening besloten met 'En hij begon te wenen'. Voor 'hij begon' staat in het Grieks het participium epibalôn, waarvan de betekenis altijd hoogst onzeker en omstreden is geweest en waarvoor de meest uiteenlopende interpretaties zijn voorgesteld. Heinsius nu wijst erop, dat Theophylactus (ca. 1100) epibalôn parafraseert met arxamenos meta sfodrotetos. 'hij begon (partic.) hevig...' ${ }^{110}$ Heinsius ziet in de woorden van Mt. 26:75 kat eklause pikrôs (met het werkwoord in een ingressieve aoristus: ' $E n$ hij begon bitter te wenen') de juiste interpretatie van de moeilijke plaats bij Mc.: het parallelvers van Mt. (26:75), zegt Heinsius, vera locı est ınterpretatıo. Verder is hij van mening, dat in de vulgata de zinsnede van Mc. 14:72 met de woorden et coepit flere op filologisch verantwoorde wijze (erudite) is vertaald.

Theophylactus heeft in dit geval, naar men ziet, de gang van Heinsius' exegetische overwegingen bepaald. Salmasius heeft in deze interpretatie aanleiding gevonden om zijn hoon over Heinsius uit te storten. Onder andere hanteert Salmasius het argument, dat epiballern om 'beginnen' te betekenen niet in het activum, maar in het medium had moeten staan. ${ }^{111}$ Op dit punt (en op andere) heeft Salmasius geheel ongelijk gekregen. In hellenistisch Grieks worden tal van transitieve werkwoorden in actieve vorm gebezigd met intransitieve (of reflexieve) betekenis. ${ }^{112}$ Tegenwoordig wordt de door Heinsius bepleite interpretatie algemeen geprefereerd of zonder meer aanvaard, bij voorbeeld in de grammatica van Blass en Debrunner (\$308), in Kittels Theologisches Worterbuch $(\mathrm{I}, 527)$ en in het Worterbuch zum Neuen Testament van W. Bauer (s.v. epıballô). ${ }^{113}$ In alle drie deze standaardwerken wordt de mogelijkheid van de interpretatie 'hij begon' mede gebaseerd op het telkens expliciet vermelde getuigenis van Theophylactus. Dat voor zover bekend Heinsius de eerste is geweest die dit belangrijke getuigenis heeft geciteerd en gehonoreerd, zal men noch daar, noch in enig ander naslagwerk of commentaar meer lezen.

$\mathrm{Nu}$ in het voorgaande is aangeduid, hoe Drusius, De Dieu en Heinsius ieder met zekere voorkeur een bepaald areaal van oudere literatuur voor de verklaring van het Nieuwe Testament vruchtbaar hebben gemaakt, is het goed te beklemtonen, dat de genoemde terreinen, judaica, oude ver-

110 Men vindt de passage van Theophylactus in Migne, $P G, 123,661 \mathrm{~d}$

111 Vanwege het onsystematısch karakter van Salmasıus' werken vindt men zijn commentaar op veel neuwtestamentısche plaatsen, ook de onderhavige, het makkelıjkst in de byzonder waardevolle notae variorum in Bald Walaeus, Novi Testamenti libr historcci, Lugdun Batavorum 1653 Bron was in dit geval De Foenore Trapezztico, Lugd Bat 1640, p 272

${ }^{112}$ Blass-Debrunner, Grammatzk des neutestamentluchen Grechisch, Gottıngen $1965^{12}, \S 308$ met aanhangsel

113 In het Theol Worterbuch $z N T$ wordt door Hauck, net als door Heinsius, aan eprbalôn in Mc 1472 nog intensieve betekenıs toegekend 'er begann bitterlich ', Heinsius 'vehementer coepit' Deze nuance van intensiteit schinnt op grond van nieuwe lexicografische gegevens als niet aan het werkwoord eigen te moeten worden beschouwd 
talingen en patristische exegese, beslist niet strikt tussen Drusius, De Dieu en Heinsius verdeeld en afgebakend zijn geweest. Elk van hen bewoog zich met gemak en bekwaam op elk van die terreinen. Daarenboven putten zowel zij als vele van hun tijdgenoten illustratief materiaal uit profane Griekse en Latijnse schrijvers. Van de goede resultaten waartoe deze veelzijdige filologische benadering kon leiden, moge nog een enkel simpel voorbeeld worden vermeld.

Heinsius kwam op grond van passages bij Homerus, Aristoteles, in de Septuagint, bij Hesychius en Hiëronymus tot de conclusie, dat het Griekse adjectief agapètos, dat gewoonlijk 'geliefd' betekent, dikwijls gebruikt wordt voor een 'enig' (uncus) kind. ${ }^{114}$ In het verhaal van Jezus' doop is 'geliefd' in Gods woorden 'Dit is mijn geliefde zoon' volgens Heinsius een inadequate vertaling. Hij wil dat men vertaalt: 'Dit is mijn enige zoon'. In 1926 heeft C. H. Turner onder verwijzing naar Heinsius diens opvatting op nieuw verdedigd op grond van een aanzienlijk uitgebreide collectie bewijsplaatsen. ${ }^{115}$ In verscheidene moderne vertalingen kan men thans het resultaat van dit inzicht aantreffen. In The Translator's New Testament van The British and Foreign Bible Society bij voorbeeld wordt agapètos op zeven plaatsen vertaald met 'dear and only', ${ }^{116}$ terwijl W. Barclay in zijn The New Testament A New Translation op deze zelfde plaatsen agapètos met 'beloved and only' weergaf. ${ }^{117} \mathrm{Na}$ meer dan drie eeuwen wordt zo in zekere zin eer betuigd aan Heinsius' kennis van het Grieks en opmerkingsgave.

Hoe nuttig de werken van Drusius, De Dieu en Heinsius om hun literair-historische methode en om hun inhoud ook waren, ze worden in bruikbaarheid verre overtroffen door de nieuwtestamentische commentaar van een andere Nederlander: de Annotationes van Hugo Grotius, verschenen te Parijs en Amsterdam van 1641 tot 1650 . Deze kunnen zonder risico als de beste bijbelse commentaar worden beschouwd die in Europa in de $17 \mathrm{de}$ eeuw is geproduceerd. Het werk ontleent zijn waarde vooral aan de talrijke, goed gekozen illustratieve aanhalingen uit klassieke, joodse en patristische bronnen die het biedt; hierdoor werd de weg verder gebaand tot het verstaan van het Nieuwe Testament in het historisch en godsdienstig kader van de tijd waarin het ontstond. Voorts is van belang, dat Grotius het waagt, over het ontstaan van enige brieven in het Nieuwe Testament historische hypothesen op te stellen, omdat de traditionele opvattingen hieromtrent hem niet met de inhoud van de brieven in overeenstemming leken. ${ }^{118}$ Het loont tot op vandaag, Grotius te raadplegen.

\footnotetext{
114 Exercitationes sacrae, pp 102 en 119

115 C H Turner, in The Journal of Theological Studies 27 (1926), pp $113-129$

116 London 1973 De plaatsen zijn Mt $317,1218,175$, Mc 111, 97,126 en Lc

2013

117 London 1968

118 Voor een korte evaluatıe van Grotıus' Annotatıones, zıe W G Kummel, Das Neue Testament Geschichte der Erforschung setner Probleme, Freıburg etc , 1970 ${ }^{2}$, pp $28-36$
} 
Met enıge weemoed ga ık hier aan hem voorbıj, daar hı aan geen enkele onderwijsinstelling in zijn vaderland verbonden heeft mogen zijn 119

De belangrijkste specimina van de 17 de-eeuwse annotatıones-commentaar zıjn hiermee genoemd Natuurlujk zıjn er meer verschenen dan de hier vermelde, zoals die van de remonstranten Simon Episcopius ${ }^{120}$ en Clericus ${ }^{121}$ Maar rondom het midden van de $17 \mathrm{de}$ eeuw heeft deze commentaarvorm zowel haar hoogtepunt als een soort verzadigingspunt bereıkt vanaf 1650 verschijnen er in de Nederlanden en daarbuiten commentaren op het Nieuwe Testament, waarm het zlj een keuze, het zij het geheel van de aantekenungen van een aantal vroegere uitleggers bijeengebracht worden In 1653 bij voorbeeld gaf Balduinus Walaeus te Leiden zijn Novı Testa mentı libr historicı uit, waarin de evangelien en Handelingen worden begeleid door een commentaar die is samengesteld uit noten gekozen uit de werken van o a Drusius, Scalıger, Gomarus, Salmasius, Heınsius en Grotıus Dergelıke cumulatieve commentaren ontstonden ook in Engeland de kolossale collectie Critıcı sacr, bezorgd door J Pearson en anderen (Londen 1660) en de Synopsis critzcorum aliorumque Sacrae Scripturae interpretum van M Poole (Polus) (Londen 1669 - 1676) Het laatste werk werd onder leıdıng van Leusden herdrukt te Utrecht (1684), van de Critıcı sacr verscheen een herdruk te Amsterdam (1698) Eigenlıjk had ook Clericus' commentaar op het Nieuwe Testament, die het licht zag in 1698, het karakter van een verzamelwerk Het bevatte de annotaties van de Engelse theoloog en criticus Henry Hammond (1605 - 1660), welke Clericus om hun kwaliteit uit het Engels in het Latın had vertaald, en daartussen de aantekenıngen van Clerıcus zelf, tussen teksthaken gezet en voorzien van zıjn naam Het werd daardoor een enigszins halfslachtıg werk, te meer doordat Clerıcus zıch nogal eens liet verleıden om commentaar te geven op Hammonds opmerkingen, die al weer van 1653 dateerden Clerıcus was een ongehoord veelzıdıg, zeldzaam hard werkend geleerde en een scherpzinnig criticus, maar doordat hij te veel, niet zelden gigantische projecten ter hand nam, toont veel van zljn werk in opzet en uitwerking niet de consequent kritische zin die vernieuwing in de wetenschap teweeg brengt Ook zijn nieuwtestamentische commentaar lijkt bij zijn capaciteiten wat ten achter te staan, al blifft dit werk door de onafhankelijke, vaak indrıngende filologische behandelıng van exegetısche kwestıes tot de beste van de tijd behoren

119 Op het oordeel dat Van Unnik over Grotıus als uitlegger van het Nicuwe Testament heeft uitgesproken meen ik echter kort te moeten ingaan zie Appendix II

120 Notae breves in Matthaeum, in zijn Opera Theologica II, Rotterdam 1665, pp 1-169 Men vindt daar ook zijn Lectiones sacrae in I Epistolam catholicam apostolt Joannis, pp 173 - 428 en zijn Lectiones sacrae in cap II et III Apocalypseos Joannis pp 429581

$121 \mathrm{~J}$ Clericus, Novum Testamentum Domint Nostr Jesu Christı cum paraphrast et Anno tatıonıbus Henricı Hammondi transtult, illustrant, auxı, I-II, Amstelodami 1698 In de 2de editıe (Francofurtı 1714), I, p 559, gaf Clerıcus voor het eerst zijn conjectuur bij Hand 16 12, boven vermeld op p 25 


\section{Harmonistische en oudheidkundige \\ verhandelingen over nieuwtestamentische stof}

Terwijl de annotationes-commentaar over zijn hoogtepunt heen raakte, ontwikkelde zich met betrekking tot het Nieuwe Testament een ander genre wetenschappelijke literatuur, dat een zekere bloei beleefde in het laatste kwart van de 17de eeuw en omtrent de eeuwwisseling: de geschiedkundige verhandeling over historische problemen die met de inhoud van het Nieuwe Testament zijn verbonden. In deze historische verhandelingen heerst naar huidige opvatting een al te weinig getemperd optimisme betreffende de reconstrueerbaarheid der oude geschiedenis en de mogelijkheid van betrouwbare kennis daaromtrent. Daardoor hebben ze, anders dan de annotationes-commentaren en de observationes-literatuur hun waarde nu bijna geheel verloren. Een beknopte vermelding van enige tot dit genre behorende werken mag hier echter niet ontbreken.

Een onweerstaanbare uitdaging voor het wetenschappelijk vernuft bleven de traditionele harmonisatie-problemen vormen, bij voorbeeld de discrepantie tussen de geslachtsregisters van Jezus in Mt. 1 en Lc. 3. Scaliger had in ca. 1605 wel gezegd, dat het hier 'une grande difficulté' betrof waarvoor hij geen oplossing zag, ${ }^{122}$ tenzij men aannam dat de genealogie van Mt. 1 eenvoudig een vroegchristelijke interpolatie, dus een corruptie in de tekst van het evangelie was, ${ }^{123}$ zoals hij er zovele meende te kunnen signaleren. ${ }^{124}$ Maar het probleem bleef fascineren. In 1627 liet Gomarus een Examen controversiarum, de Genealogia Christi... (Groningae 1627) verschijnen, geschreven in de periode van zijn hoogleraarschap te Groningen (1618 - 1641). Gomarus poogt Mt. en Lc. met elkaar te verzoenen door te argumenteren, dat Jozef, Jezus' pleegvader, de zoon was van Jacob over wie de genealogie bij Mt. loopt en tevens de schoonzoon van Eli over wie de geslachtslijst van Lc. loopt. De ene lijst volgt de natuurlijke afstamming, de andere een juridische. ${ }^{125}$ Weldra volgde van G. J. Vossius, sinds 1632 hoogleraar aan het Amsterdamse Athenaeum Illustre, een Dissertatio gemina, Vna de Iesu Cristi (sic) genealogia, Altera de Annis, quibus natus, baptizatus, mortuus (Amsterdami 1643). In het eerste stuk van deze verhandeling onderzoekt Vossius diverse pogingen tot verzoe-

122 Secunda Scaligerana, p. 340.

123 'Notae quaedam Scaligeri in Novum Testamentum quas Francisco Vertuniano aliud agens communicavit', in Parijs, Bibliothèque Nationale, MS. Coll. Dupuy 395, fol. 19r. 124 Secunda Scaligerana, pp. 398 en 399.

125 Zie ook G. P. van Itterzon, Franciscus Gomarus, 's-Gravenhage 1930, pp. $369-370$. 
ning van de twee genealogieen en kiest hij voor de oplossing, dat Mt. de natuurlijke afstamming van Jozef biedt, Lc die van Maria. Daarbij meent hij, dat Lc. zijn geslachtsregister terugvoert tot op Adam, omdat hij in het Grieks schreef voor een universeel publiek, dat niet met de verwantschap tussen Jozef en Maria op de hoogte was en dat dus de lijn van Maria tot Adam volledig uitgeschreven moest krijgen. Deze terugvoering op Adam was voor $\mathrm{Mt}$. niet nodig, omdat die in het Hebreeuws voor een Hebreeuws publiek schreef, dat van de verwantschap tussen Maria en Jozef op de hoogte was, zodat het genoeg was, indien Mt. zijn genealogie van Abraham over David tot op Jozef liet afdalen. Hetzelfde onderwerp werd nog eens aangesneden door Jacques Gaillard, de regent van het Waalse College te Leiden (1669 - 1688) in zijn La généalogıe de Jésus Chrıst (Leiden 1683) ${ }^{126}$ en door Guilelmus Surenhusius, professor Hebreeuws (1704 -) en Grieks (1709 - 1729) aan het Athenaeum Illustre te Amsterdam, in zijn 'Conciliationes de Genealogia Jesu Christi', opgenomen in zijn Biblos Katallages (Amstelaedami 1713), ${ }^{127}$ om van andere behandelingen van het thema nu te zwijgen.

De Groningse wijsgeer M. Schoockius verdiepte zich in zijn 'Quinam sint Asıarchae apud Lucam, Actorum XIX' (1663) ${ }^{128}$ in de vraag, wat precies de Asiarchen van Hand. 19:31 waren. De Statenvertalers hadden een probleem geschapen door in de kanttekening ter plaatse op te merken, dat de Asiarchen organisatoren van feesten ter ere van heidense goden waren en daaraan toe te voegen dat sommige van hen christenen waren. Schoockius zet uiteen, dat de functie van Asiarch in Paulus' tijd alleen een titulaire was, zodat tot het christendom overgegane Asiarchen zich niet met heidense spelen inlieten, noch zich aan idololatrie bezondigden. Schoockius' betoog is overigens niet door puur historische interesse ingegeven, maar wil bijbelse steun geven aan een ant1-voetıaans standpunt in een bepaald toenmalig kerkelijk conflict. Een polemische inslag kan evenmin worden ontzegd aan de uitvoerige en degelijke verhandeling van de Leidse hoogleraar theologie Fred. Spanheim jr. (1670 - 1701) getiteld 'De temerè creditâ Petri in urbem Romam profectione' van $1679 .{ }^{129}$ Het is een grondige weerlegging van de door protestantse historici zijns inziens al te lichtvaardig aanvaarde katholieke traditie volgens welke Petrus te Rome zou zijn geweest en er het episcopaat zou hebben vervuld. ${ }^{130}$ Het tractaat werd gebundeld met enkele andere historische verhandelingen, waaronder

126 Zie ook G H M Posthumus Meyjes, Geschiedents van het Waalse College te Letden, Leiden 1975, pp $133-134$

127 Brblos Katalleges in quo secundum veterum theologorum Hebraeorum formulas allegand, et modos interpretandi conclinantur loca ex $V$ in $N$ T allegata, Amstelaedami 1713, pp $113-169$

${ }_{128} \mathrm{M}$ Schoocklus, Exerctiationes vanae de diversis materns, Trajectı ad Rhenum 1663, pp $183-190$

129 Fred Spanheım (fil ), Dissertationum histoncı argumentı quaternıo, Lugdunı Batavorum 1679

130 Over Spanheıms verhandelıng en zijn afhankelıkheıd van de 16de-eeuwse Boheemse auteur Ulrichus Velenus Minhoniensıs, zıe A J Lamping, Ulrichus Velenus, Leiden 1975, pp $202-204$ en elders 
een over de datum van Paulus' bekering en een over het apostelambt en de apostelen.

Tot het terrein van de harmonistiek wederom, maar niet minder tot dat van de geleerdenruzies, behoort een aantal geschriften van de Leidse graecus Jacobus Gronovius (1679 - 1716) en zijn collega de historicus Jacobus Perizonius (1693 - 1715) over de dood van Judas. ${ }^{131}$ In 1683 verschenen Gronovius' Exercitationes academicae de pernicie et casu Judae tô̂ prodítou. Hierin poogde Gronovius de uiteenlopende berichten over Judas' dood van Mt. 27:5 en Hand. 1:18 met elkaar in overeenstemming te brengen door de woorden 'voorover gevallen scheurde hij midden door' van Hand. 1:18 slechts te doen slaan op het reeds ontzielde lichaam van Judas, die tevoren zou zijn omgekomen door verhanging overeenkomstig Mt. 27:5. Zonder Gronovius te noemen kritiseerde Perizonius deze harmonisatiepoging van zijn collega in zijn editie van Aelianus' Varia Historica (1702), in een aantekening op V, 8 en stelde er een andere harmonisatie voor in de plaats - overigens een al even traditionele als Gronovius voorgesteld had. ${ }^{132}$ Volgens Perizonius kon het werkwoord apanchesthai waarmee Mt. de dood van Judas aanduidt 'zelfmoord plegen' in het algemeen betekenen en behoefde het niet specifiek op verhanging te slaan: Mt. zou slechts het feit van de zelfmoord (niet: verhanging) hebben gemeld, Hand. daarentegen de precieze toedracht, nl. een val, hebben beschreven. Gronovius begreep dat de kritiek tegen hem gericht was en reageerde met een herdruk van zijn tractaat uit 1683, uitgebreid met een Defensio (1702) waarin hij zijn positie handhaafde. Achtereenvolgens verschenen nu: van Perizonius een Dissertatio de morte Judae et verbo apanchesthai, in qua explicantur et conciliantur loca S. Matthaei XXVII.5 et Lucae Actor. I.18 ... (1702), van Gronovius een Notitia et illustratio dissertationis nuperae de morte Judae et verbo apanchesthai (1703), van Perizonius een Responsio ad nuperam notitiam (1703) en na de repliek van Gronovius nog een tweede Responsio van Perizonius (1703). De toekomst zou geen der strijdenden gelijk geven.

In 1682, aan het begin van zijn hoogleraarschap in de welsprekendheid en geschiedenis te Franeker (1682 - 1693) had Perizonius een dissertatie laten verdedigen en gepubliceerd over de bevolkingsregistratie onder Augustus waarvan in Lc. 2:1 - 4 melding gemaakt wordt. ${ }^{133}$ Perizonius betoogt, dat het woord apografe in Lc. 2:1 niet 'schatting', maar 'volkstelling' betekent. Voorts wil hij de bekende chronologische problemen van vers 2 te boven komen door het als volgt te interpreteren: 'Deze inschrijving vond plaats voordat Quirinius het bewind over Syrië voerde'. Er zouden dan twee volkstellingen geweest zijn: een onder Quirinius en een andere tien jaar eerder, waarover Lc. 2:1 - 5 gaat. Deze interpretatie,

131 T. J. Meijer, Kritiek als herwaardering. Het levenswerk van Jacob Perizonius (1651 -1715), Leiden 1971, pp. 137 - 141.

${ }^{132}$ De oplossing van Perizonius was hier te lande reeds bepleit door Grotius in zijn Annotationes op Mt. 27:5 en door G. J. Vossius in zijn Harmonia evangelica, Amsterdam 1656, p. 216.

133 Meijer, Perizonius, pp. 56 - 57, 215. 
waarvan Perizonius niet de eerste verdediger was, ${ }^{134}$ heeft tot in de $19 \mathrm{de}$ eeuw aanhangers gehad, maar ze is uiteindelijk een gezochte, onaanvaardbare noodoplossing die slechts diende om de chronologie van Lc. met die van Josephus en Tertullianus in overeenstemming te brengen.

Eveneens nog te Franeker liet Perizonius zijn verhandeling over de betekenis van het woord praetorium en de strekking die in verband daarmee Philip. $1: 13$ heeft verschijnen (1687). ${ }^{135}$ Naar aanleiding van deze publicatie, in oorsprong een door Perizonius geschreven en onder hem verdedigde dissertatie, ontbrandde een hevig conflict met zijn juridische collega Ulrich Huber. Het centrale geschilpunt was, of praitôrion in Philip. $1: 13$ op de rechtszaal in het keizerlijk paleis te Rome slaat, zo Huber, dan wel op een veldheerstent in een legerplaats buiten de stad Rome of in enige provincie, aldus Perizonius. In het laatste geval behoeft men niet aan te nemen, dat Paulus zich verantwoord heeft in Nero's paleis en in bijzijn van Seneca, zoals men nog steeds graag geloofde. Deze romantische aspecten spelen thans in de kwestie geen rol meer, de problematiek is niettemin serieus en mede van belang voor localisering en datering van de Philippenzenbrief. Zeker had Perizonius in dit geval het gelijk meer aan zijn kant dan zijn tegenstander. Aan de polemische geschriften die over en weer vlogen moge hier worden voorbijgegaan. Slechts zij nog opgemerkt, dat de student door wie Perizonius zijn eerste verhandeling over het praetorium had laten verdedigen Johannes Sibranda was, die zich later als lector Grieks te Franeker (1693 - 1696) eveneens op nieuwtestamentisch gebied begaf met verhandelingen als De origine et vera significatione vocum chorègein et epichorègein en De statu Judaeae provinciae. ${ }^{136}$ Van Perizonius zelf tenslotte zijn er nog studies over onderwerpen als: de doodstraf bij de joden ten tijde van Jezus naar aanleiding van Joh. 18:31, de berichten van Josephus over Jezus en Jacobus, de chronologie van 450 jaar richterschap over Israel vermeld in Hand. 13:20 en de betekenis van anastèsas in Hand. $13: 33$, buitendien liet hij uitgebreide aantekeningen op Matthaeus na. ${ }^{137}$

Interesse voor de oudheden van het Nieuwe Testament ontbreekt op het einde van de 17 de eeuw en in het begin van de $18 \mathrm{de}$ eeuw ook de theologische hoogleraren niet. De twee toenmaals meest op de voorgrond tredende, aan een theologische faculteit verbonden professoren waren wel de coccejaan Hermannus Witsius, achtereenvolgens hoogleraar te Franeker (1675 - 1680), Utrecht (1680 - 1698) en Leiden (1698 - 1707) en de gematigde voetiaan Johannes a Marck, successievelijk hoogleraar te Franeker (1676 - 1682), Groningen (1682 - 1689) en Leiden (1689 1731). Behalve een deel van hun carrière hebben zij hun onverdroten

134 In M. Polus' Synopsis criticorum wordt dezelfde interpretatie vermeld op naam van de Wittenbergse hoogleraar en uitlegger van het Nieuwe Testament Erasmus Schmidius (Schmidt; gestorven 1637), wiens vertaling van het N.T. met aantekeningen verschenen is te Neurenberg in 1658.

135 Meijer, Perizonius, pp. $74-76$.

136 Meijer, Perizonius, p. 123.

137 Meijer, Perizonius, pp. 95 - 96 en 208.

SIBRANDA, J. Dissertatio philoi. de Macello et vera interpretatione I. Corinth. 
ijver, hun productiviteit en de sterk dogmatische tendens in hun exegese gemeen. Het laatste heeft tot gevolg, dat veel van hun op het Nieuwe Testament betrekking hebbende geschriften thans van een haast hermetische ondoordringbaarheid is. Wat Witsius betreft, zelfs van het geringste sprankje literaire of historische kritiek is hij welbewust afkerig, ${ }^{138}$ althans zolang het kanonieke teksten betreft, want over de extra-kanonieke pseudo-paulina weet hij vaardig te oordelen. ${ }^{139}$ In zijn Miscellanea sacra van 1700 komt een 'Exercitatio de vita Johannis Baptistae' voor van negentig pagina's. Witsius presteert het, hierin het testimonium van Flavius Josephus zo goed als buiten beschouwing te laten: in één korte paragraaf citeert hij in het voorbijgaan Josephus' getuigenis tesamen met twee passages uit rabbijnse bronnen, noemt ze onverstoorbaar 'plus minus consentaneae' met de 'evangelica historia' en dat is alles: geen enkele discussie wordt aan Josephus besteed. In hetzelfde werk komt een uitgebreide 'Historia Hierosolymae' voor en in de Meletemata Leidensia van 1703 een leven van Paulus, maar het is alles, hoewel soms geleerd, toch steeds oppervlakkig, harmonistisch en onkritisch. Joh. a Marck laat aan filologische observaties en overwegingen veel méér vrij spel. Rustig overweegt hij de literaire gegevens en de opinies van vroegere geleerden. Disputaties als die over 'de doop voor overledenen' (I Cor. 15:29) ${ }^{140}$ en verhandelingen over de joodse wassingen bedoeld in Mc. 7:3 (pugmèi) en over wat precies de fatné in Lc. 2:7, 12 en 16 was, ${ }^{141}$ zijn nog leesbaar, maar zowel zijn argumenten als zijn oplossingen zijn erg traditioneel. Steeds staat een dogmatisch bepaald, onaangetast vertrouwen in de deugdelijkheid van een harmonistisch samengesteld beeld der bijbelse geschiedenis een echt grondige en onafhankelijke beoordeling van de literaire gegevens van meet aan in de weg.

Dit laatste oordeel treft niet alleen A Marck en Witsius, ook niet alleen de theologen onder de geleerden die zich met het Nieuwe Testament bezig hielden, maar in het algemeen ook de filologen onder hen. Van literaire en historische kritiek kan, voor zover het het Nieuwe Testament betreft, in de 17 de eeuw nog nauwelijks gesproken worden. Een begin van zulke kritiek treft men bij Scaliger, zijn pupil Grotius, zijn opvolger Salmasius en bij Clericus. Scaliger verwierp op literair-kritische gronden de authenticiteit van niet minder dan acht nieuwtestamentische geschriften ${ }^{142}$ en verwierf

138 Cf. J. van Genderen, Herman Witsius. Bijdrage tot de kennis der gereformeerde theologie, 's-Gravenhage 1953, pp. 108 - 123: 'Witsius als Exegeet', waar de sterk dogmatische insiag in Witsius' exegese, alsmede zijn afkeer van tekst-, literaire en kanonkritiek geregistreerd wordt.

139 In zijn Meletemata Leidensia, Lugd. Batavorum 1703, pp. 228 - 246.

140 In de uit zijn Franeker periode daterende Exercitationes Juveniles, mij toegankelijk in Joa. Marckius, Opuscula prima philologıco-theologica, I, Groningae 1748, pp. 280 - 297.

141 Joh. Marckius, Textuales Exerctationes ad quinquaginta selecta loca Veterts et Novi Testamenti, Amstelaedami 1694, respectievelijk pp. 324 - 331 (over Mc. 7:3) en pp. 332 -343 (over Lc. 2:7 etc.).

142 Cf. Lunsingh Scheurleer ed, Leiden Universtty in the Seventeenth Century, p. 84. Het betreft Hebr., Jac., II Petr, I, II, III Joh., Jud en Openb. 
zich hierdoor een markante plaats in de kanongeschiedenis. ${ }^{143}$ En wat belangrijker is: hij wees harmonisering van tegenstrijdige berichten in het Nieuwe Testament of van nieuwtestamentische berichten met afwijkende tradities bij profane auteurs radicaal af. $\mathrm{Hij}$ zag bij voorbeeld scherper dan wie ook in zijn tijd en dan velen in onze, dat het verhaal van de dood van Johannes de Doper in Mc. 6 volstrekt onverenigbaar en onverzoenbaar is met het corresponderende verhaal bij Josephus. Maar hij zag dan weer geen andere verklaring voor zulke contradicties dan ze toe te schrijven aan secundaire ingrepen van christenen in de tekst van de evangeliën: hij verwarde aldus zijn historische kritiek met tekstkritiek. Een beter, ja verbluffend scherp inzicht in deze problematiek toonde Salmasius bij de beoordeling van de tegenstrijdige verhalen over de dood van Judas in Mt. 27 en Hand. 1. Hij merkt op, dat hij geen mogelijkheid ziet beide berichten met elkaar in overeenstemming te brengen: ze geven werkelijk verschillende voorstellingen van zaken. De oorzaak hiervan is, meent Salmasius, dat alleen was overgeleverd, dat Judas zich van het leven had beroofd, maar niet op welke manier: 'Op welke manier hij is omgekomen, was onbekend. (...) Sommigen hebben overgeleverd, dat het was door een val, anderen door verhanging'. ${ }^{144}$ Met zeldzame scherpzinnigheid beschouwt Salmasius hier verschillende verhalen als resultaat van divergerende tradities en schrijft hij de divergentie toe aan het ontbreken van informatie. Een visie, waarbij Clericus een halve eeuw later welbeschouwd nog ten achter blijft. In 1699 liet hij de evangeliën in het Grieks in vier parallelle kolommen zo afdrukken, dat inhoudelijk corresponderende verhalen naast elkaar kwamen te staan. Dit was de eerste Griekse synopsis van de evangeliën. ${ }^{145}$ Voor zover nu de corresponderende verhalen met elkaar overeenstemden, beschouwde hij ze, volgens zijn toelichting in een appendix, als verslag van één historisch gebeuren; de discrepanties zag hij als de varianten die natuurlijkerwijze optreden wanneer meerdere personen van hetzelfde gebeuren verslag doen. Clericus kon dus, dankzij zijn afwijzing van de massieve leer van de woordelijke inspiratie zoals die nog maar al te gangbaar was in zijn tijd, aanvaarden, dat de evangeliën in details onderlinge verschillen vertonen die niet harmoniseerbaar zijn; doch overigens zocht hij naar de éne gemeenschappelijke historische kern. Zo geeft Clericus wel blijk van een rationalistische bronnenkritiek, maar niet van de radicale traditio-historische benadering van Salmasius. Intussen moet men zich goed realiseren, dat het in de genoemde opvattingen van Scaliger, Salmasius en Clericus om enkele geïsoleerd staande hoogtepunten gaat. Algemeen domineerde nog de neiging om de bijbelse verhalen direct als geschiedgebeuren op te vatten en om verschillen te harmoniseren.

143 Deze plaats kon wel wat beter beschreven worden dan reeds gedaan is door J Leipoldt, Geschichte des neutestamentlichen Kanons, I - II, Leipzig 1907 - 1908, II, p $157-158$ 144 'Quo genere mortıs perısset, incertum habebatur Alı praecipitıo, alı suspendio extınctum tradiderunt', geciteerd naar Bald Walaeus, Novi Testamenti Libri Historici, p 317

$145 \mathrm{~J}$ Clericus, Harmonıa Evangelıca, Amstelodamı 1699, p 524 Overeenkomstige ideeen uitte Clericus in zijn Five Letters Concerning the Insperation of the Holy Scriptures, London 1690 


\begin{tabular}{cccc}
\hline MATTHEUS. & MARCUS. & LUCAS. & JOANNES. \\
CA P. XIV. & CA P. VI. & C A P. IX. $_{\text {A P. VI. }}$
\end{tabular}

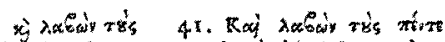

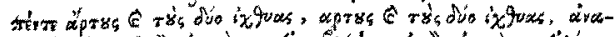

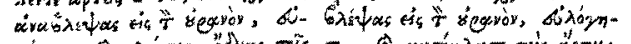

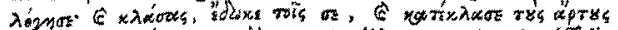
mos

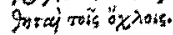

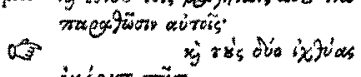
iprígar muitos. s.

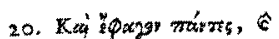

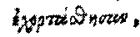

as $42.10 \%$

$$
\text { ris }
$$

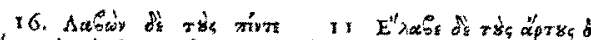

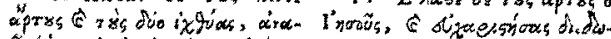

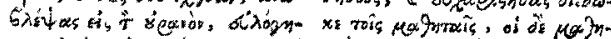

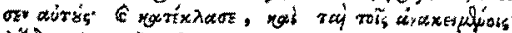

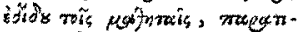

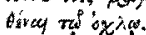

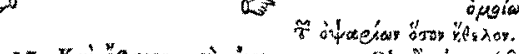

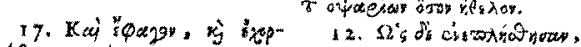

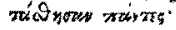

$\operatorname{los}^{x}$ Xíge row

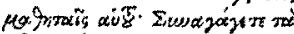

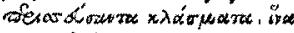

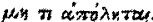

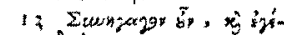

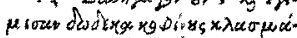

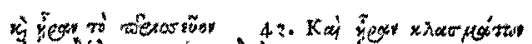

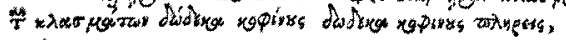
anifers:

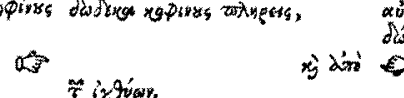

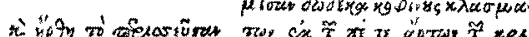

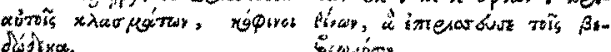
diskrg.

$\Leftrightarrow$

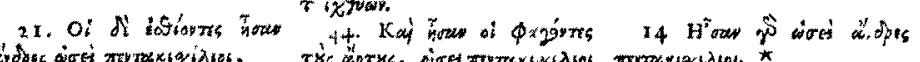

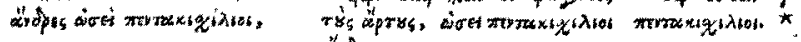
aydows. xaess so

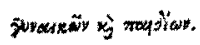

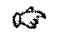

and

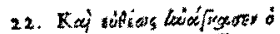

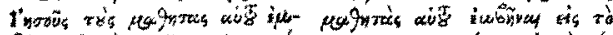

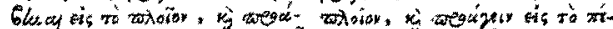

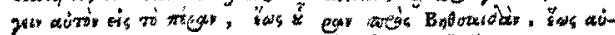

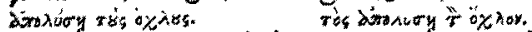

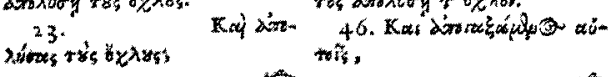

4

Rิ⺈

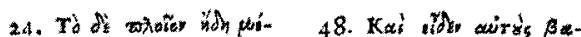

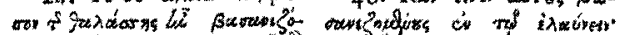

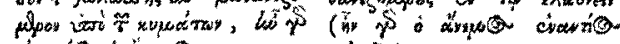

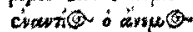

a.s acton

25. Temipry distaxis

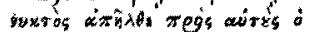

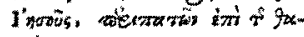

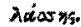

of cropler to to opos

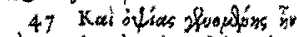

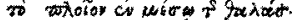

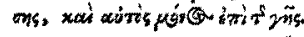
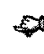

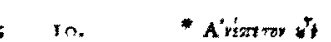

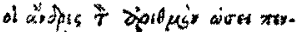
rexighisor. 20

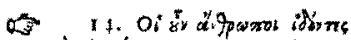

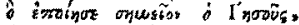

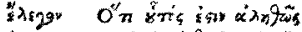

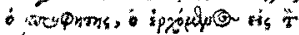
$x \sigma^{\prime}, 29 *$

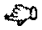

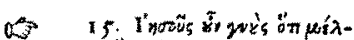

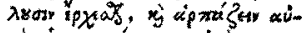

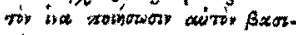 Xix,

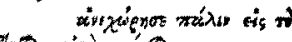

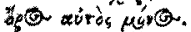

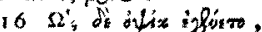

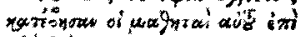 riet páxuos aw.

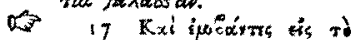

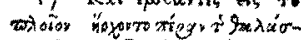

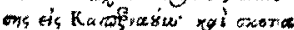

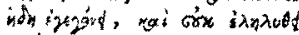

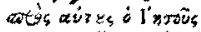

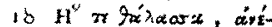

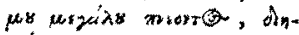 Yistor.

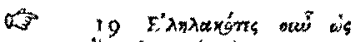

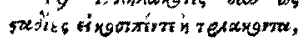 $\Leftrightarrow$

8. Detail uit de synopse van Clericus, de Harmonia Evangelica, Amsterdam 1699. Fragment uit de spijziging van de vijf duizend, Matth. 14:19vv., Mc. 6:41vv., Lc. 9:16vv. en Joh. 6:11vv. Schaal 1:1,2. 


\section{Vroegchristelijke letterkunde}

Literair-historische kritiek kon zich in de hier besproken periode vanzelfsprekend beter ontplooien op het gebied van de niet-kanonieke vroegchristelijke literatuur dan op dat van het Nieuwe Testament binnen de kanon. Op dit terrein valt inderdaad heel wat beweging waar te nemen. Ook hier neemt Scaliger weer een vooraanstaande plaats in. Om enkele van zijn bijdragen te noemen: op onweerlegbare literaire gronden bewees hij, dat de Constitutiones Apostolicae en de Canones Apostolorum niet in de eerste, maar in de vierde of vijfde eeuw thuis horen. ${ }^{146} \mathrm{Hij}$ was de eerste die (Ps.-) Phocylides van de zesde eeuw voor Chr. naar de vroegchristelijke literatuur verwees. ${ }^{147}$ Ook ten aanzien van Dionysius Areopagita toonde hij overtuigend aan, dat de op zijn naam staande geschriften niet in de eerste eeuw, maar op zijn vroegst in de vijfde eeuw ontstaan zijn. Het insisteren op deze datering was nog allerminst overbodig, daar Baronius en Bellarminus aan de authenticiteit van de Areopagitische geschriften bleven vasthouden. ${ }^{148}$ Voorbeelden als deze maken duidelijk, hoeveel er op het gebied van de vroegchristelijke literatuur in de 17 de eeuw nog te doen stond.

De namen van twee Leidse geleerden zijn verbonden met de tekstgeschiedenis van Polycarpus' brief aan de Philippenzen en de brief op naam van Barnabas: Salmasius en Estienne le Moyne.

De brief van Polycarpus was voor het eerst in het Grieks uitgegeven door P. Halloix te Douai in 1633. In 1644 zond James Ussher er te Oxford op nieuw een editie van in het licht. Hieraan had hij een manuscript ten grondslag gelegd, dat door Salmasius persoonlijk was afgeschreven uit een exemplaar in het bezit van de Antwerpse jezuïet Andreas Schottus (1552 1629). ${ }^{149}$ Salmasius had zijn afschrift aan Isaac Vossius gegeven en die had het weer doorgegeven aan Ussher. Daar evenwel Schottus' manuscript reeds vergeleken was door de editor princeps Halloix, was het gebruik van Salmasius' afschrift door Ussher wetenschappelijk niet van bijzonder groot

146 H. J. de Jonge, 'J. J. Scaliger's De LXXXV Canonibus Apostolorum Diatribe', Lias 2 (1975), pp. 115 - 124 en 263.

${ }_{147}$ P. W. van der Horst, The Sentences of Pseudo-Phocylides, Leiden 1978, pp. 3 - 6. Ook D. Heinsius hield (Ps.-) Phocylides voor een christelijk werk, zie zijn Exercitationes Sacrae, p. 559 .

148 J. Bernays, Joseph Justus Scaliger, Berlin 1855, reprint Osnabrück 1965, pp. 80 - 81, $205-206$.

${ }^{149}$ J. B. Lightfoot, The Apostolic Fathers. II, iii, London 1889, pp. 318 - 320. 
belang. Een wat nuttiger rol speelde het bewuste handschrift van Salmasius voor de zogenaamde brief van Barnabas, doch uiteindelijk ook in dat geval zonder duurzaam gunstig resultaat.

Barnabas werd voor het eerst in het Grieks uitgegeven door Ussher te Oxford in 1643, maar de oplage ging bij een grote brand geheel verloren. ${ }^{150}$ Deze editie van Barnabas had Ussher gebaseerd op hetzelfde van Salmasius afkomstige handschrift als waarop zijn Polycarpus-editie berustte, het handschrift dus dat Salmasius van Schottus' exemplaar had afgeschreven. Thans is het door Ussher 'codex Salmasianus' gedoopte handschrift van Polycarpus en Barnabas zoek of niet meer identificeerbaar met één der bekende manuscripten van deze geschriften. ${ }^{151}$ De bereisde, maar niet aan een universiteit verbonden Isaac Vossius, via wie de codex Salmasianus Ussher bereikt had, gaf in 1646 - het zij hier slechts aangestipt de editio princeps - van de nu doorgaans als authentiek beschouwde middellange Griekse recensie van de brieven van Ignatius van Antiochië in het licht. ${ }^{152}$ Hij voegde er een nieuwe editie van Barnabas aan toe, die hij baseerde op enkele andere handschriften dan dat afkomstig van Salmasius.

Estienne (Stephan) le Moyne, hoogleraar theologie te Leiden (1676 1689), ${ }^{153}$ liet in zijn tweedelige Varia Sacra van 1685 een tekst, vertaling en commentaar van wederom Polycarpus en Barnabas verschijnen. Het was een niet in alle opzichten even geslaagde onderneming. Le Moyne beschikte over een copie van het relatief belangrijke Florentijnse handschrift van Polycarpus en Barnabas, maar blijkt daar, na ontdekt te hebben dat ook in dit handschrift Polycarpus niet in zijn oorspronkelijke omvang voorkomt doch naadloos van 9:2 in Barnabas 5:7 overgaat, geen enkel gebruik meer van gemaakt te hebben en eenvoudig de editie van Halloix te hebben nagedrukt. ${ }^{154}$ De commentaar is die van een erudiet, versatiel en inventief geleerde, maar hij is ook wijdlopig en verwijdert zich vaak ver van de teksten in kwestie. Le Moyne is waarschijnlijk de eerste die naar aanleiding van het meervoud epistolas in Polycarpus 3:2 de hypothese heeft ge-

$150 \mathrm{~J} . \mathrm{W}$. Backhouse, The edtio princeps of the Epistle of Barnabas by Archbishop Ussher, as printed at Oxford A.D. 1642, Oxford 1883.

151 R. A. Kraft en P. Prigent, Epître de Barnabé (Sources Chrétiennes 172), Paris 1971, p. 52, n. 1. Over Salmasius' en Vossius' rol in de tekstgeschiedenis van Barnabas zie men ook Vossius' noten op Barnabas achterin zijn S. Ignatiz Martyris Epistolae genuinae ... Adhaec S. Barnabae Epistola, Amstelodami 1646; Londini $1680^{2}$ en Usshers voorwoord tot zijn Barnabas-uitgave, ook afgedrukt in J. Clericus, ed., SS. Patrum qui temporibus Apostolicis floruerunt ... Opera, Amstelaedami $1724^{2}$, I, pp. 11 - 12.

152 Zie voor de titel de voorgaande noot.

153 Een goede schets van zijn leven en werk vindt men in Sepp, Godgeleerd Onderwijs, II, pp. 251 - 258. Le Moyne was in correspondentie met Richard Simon, die hem inlichtingen vroeg over het te Leiden berustende Grieks-Arabische lectionarium thans Or. 243, lectionarium 6 van het Nieuwe Testament. Le Moyne beschouwde dit MS. terecht als uit Egypte afkomstig en van jonger datum dan Scaliger en Heinsius hadden gedacht; zie R. Simon, Histoire critique des versions du Nouveau Testament, Rotterdam 1690, pp. 209 - 211; H. J. de Jonge, 'Joseph Scaliger's Greek-Arabic Lectionary', Quaerendo 5 (1975), pp. 143 172, zie pp. $151-152$ en 162.

154 Lightfoot, Apostolic Fathers, II, iii, pp. 319 - 320. 


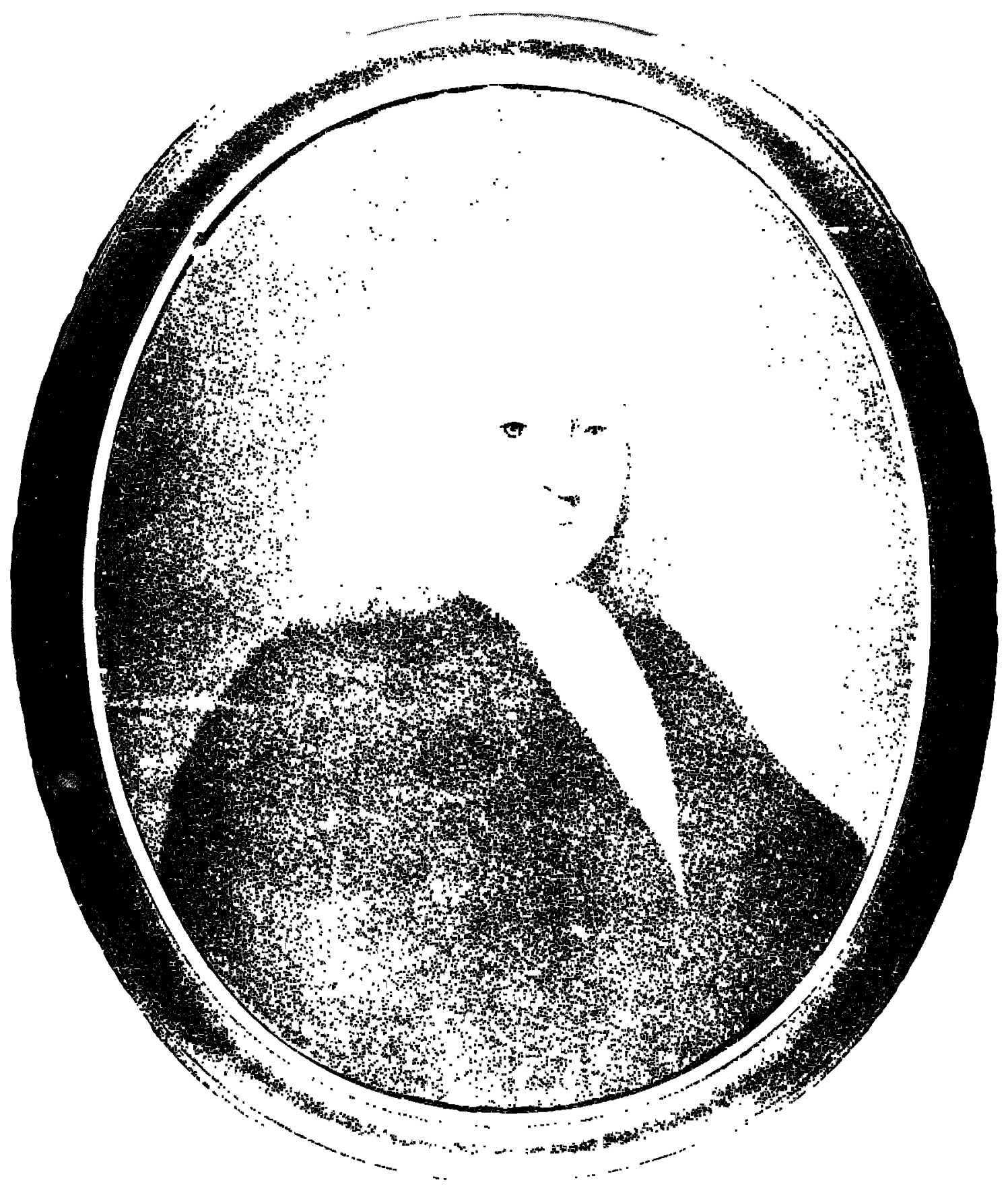

9. Johannes Clericus (Jean Le Clerc), ca. 1710. 
lanceerd, dat in de kanonieke Philippenzenbrief van Paulus twee brieven gecombineerd zijn. ${ }^{155}$ Deze hypothese heeft in diverse variaties een lang leven geleid. ${ }^{156}$

Verreweg de voornaamste Nederlandse prestatie op het gebied van de vroegchristelijke letterkunde is de monumentale editie van de Apostolische Vaders van Clericus: de SS. Patrum qui temporibus Apostolicis floruerunt ... Opera (Antverpiae 1698). Dit werk was in beginsel een heruitgave van het gelijknamige werk van Jean B. Cotelier, dat verschenen was te Parijs in 1672. In deze voorbeeldige uitgave had Cotelier voor het eerst Barnabas, Hermas, I en II Clemens, Ignatius en Polycarpus bijeen gebracht, benevens zulke werken als de Constitutiones Apostolicae en de Pseudo-Clementina. Aangezien echter de editie van Cotelier voor een groot deel door brand was verwoest en exemplaren ervan schaars waren, was een heruitgave als Clericus deed verschijnen bijzonder nuttig. Een vermeerderde en verbeterde editie bezorgde hij in 1724 in Amsterdam. Het grote belang van Clericus' edities is mede gelegen in de talrijke geleerde toevoegingen die hij in extenso opnam: voorwoorden uit vroegere edities, kritische verhandelingen en polemieken over de onderscheiden geschriften, collaties van door Cotelier niet gebruikte handschriften en brieven van $17 \mathrm{de}$ eeuwse geleerden speciaal op de Apostolische Vaders betrekking hebbende. Voorts bood hij de verklarende aantekeningen van een groot aantal critici, antieke testimonia en uitvoerige registers en indices. ${ }^{157}$ Clericus' uitgave van de Apostolische Vaders is reeds een internationale wetenschappelijke bibliotheek op zich zelf. In dit werk toont Glericus zich de ware polyhistor, zoals met name de $18 \mathrm{de}$ eeuw er zovele zou kennen. Het rusteloos vergaren van ongelooflijke hoeveelheden goed wetenschappelijk materiaal heeft ook in dit geval de rustige bezinning, kritische verwerking en zelfstandige beoordeling wel wat in de weg gestaan. Maar al is Clericus' uitgave van de Apostolische Vaders in wezen een grootscheepse compilatie, het is niettemin een indrukwekkend monument van wetenschap.

155 Varia Sacra II, pp. 332 en 343.

156 W. G. Kümmel, Einleitung in das Neue Testament, Heidelberg $1973^{17}$, pp. $291-294$. 157 J. A. Fischer, 'Die ältesten Ausgaben der Patres Apostolici, Ein Beitrag zu Begriff und Begrenzung der Apostolischen Väter', Historisches Jahrbuch 94 (1974), pp. 157 - 190; 95 (1975), pp. $88-119$. 


\section{Conclusie}

Voor de beschrijving van de geschiedenis van de nieuwtestamentische wetenschap aan de Noordnederlandse universiteiten en het Remonstrants seminarie tot 1700 vormen 'traditie' en 'vernieuwing' althans tot op zekere hoogte bruikbare categorieën. De traditie toonde haar kracht in de vitaliteit van de dogmatisch geconditioneerde exegese, in de heerschappij van de textus receptus, in de hardnekkige zucht tot historiseren en harmoniseren van de evangeliën en in het optimistisch vertrouwen in de mogelijkheid van een betrouwbare reconstructie van een bijbelse geschiedenis en chronologie. Vernieuwing daarentegen treedt aan de dag in schuchtere pogingen tot het aanleggen van varianten-collecties, in intense aandacht voor de historische plaats, de aard en de grammatica van het nieuwtestamentisch Grieks, in de uitgave en bestudering van antieke vertalingen, in incidentele, nog onsamenhangende blijken van indringende historische en literaire kritiek en bovenal in de opheldering van het Nieuwe Testament met behulp van materiaal uit tal van joodse, heidense en oude christelijke bronnen.

Met een vergelijking tussen de instellingen moet men erg voorzichtig zijn, zowel omdat bij voorbeeld Leiden in de hier behandelde periode tweemaal zo lang bestaan heeft als Utrecht en het Remonstrants seminarie, als omdat verscheidene geleerden van de ene naar de andere universiteit trokken. Drusius ging van Leiden naar Franeker, Witsius van Franeker via Utrecht naar Leiden en A Marck van Franeker via Groningen eveneens naar Leiden. Zulke dingen moet men in aanmerking nemen, wanneer men constateert dat Leiden met mannen als Scaliger, Erpenius, De Dieu, Heinsius, Salmasius en Fred. Spanheim de zoon, boven de andere hogescholen uitrijst. Franeker met Drusius, Pasor en Bos en Amsterdam met Curcellaeus en Clericus volgen. Eerst dan komen Groningen met Schoockius en Utrecht met Leusden. Harderwijk heeft voor het Nieuwe Testament weinig betekend.

Het belangrijkste wat de Nederlandse nieuwtestamentische wetenschap van de 17 de eeuw heeft voortgebracht zijn waarschijnlijk, naast een aantal uitgaven van oude versiones, de annotationes-commentaren als die van Drusius, Heinsius en De Dieu, uiteindelijk ook die van Grotius. Juist in de aandacht voor de oosterse vertalingen en in de brede historische, literaire en linguistische interesse waarmee in de annotationes-commentaren het Nieuwe Testament wordt benaderd, is - het minst nog bij Drusius en het meest bij Grotius - de invloed en inspiratie van één geleerde tastbaar: 
Joseph Scaliger. Zelf heeft hij zich in geen enkel speciaal werk uitvoerig met het Nieuwe Testament ingelaten. Hij had zich andere taken gesteld, die hij ook heeft volbracht; wat van zijn bemoeienissen met het Nieuwe Testament rest, zijn uitsluitend parerga, al zijn die al imponerend genoeg. Maar op zijn voorgang hebben eigen en indirecte leerlingen, hoewel geen theologen maar historici en filologen, het Nieuwe Testament in volle vrijmoedigheid bij het terrein van hun literair-historische wetenschappelijke activiteit ingelijfd. Hun commentaren zijn realisaties van het omvangrijke programma vervat in het schijnbaar simpele parool dat Scaliger de uitleggers van het Nieuwe Testament heeft meegegeven: 'Lisez les bons Auteurs, la Metamorphose d'Ovide, le Thalmud, illa sunt necessaria ad Biblia'. ${ }^{158}$ 


\section{Appendix I. De vermeende rol van G. Voetius in de polemiek over het Hellenistisch Grieks}

Paul Sellın vermeldt in zıjn boek over Danıel Heinsıus, dat in de herfst van 1641, toen Heinsıus en Salmasius in hevige twist met elkaar gewikkeld waren, 'nog een andere aanval op Heinsıus verscheen, een De lingua Hellenistıca, gewoonlyk toegeschreven aan Gijsbert Voetıus, professor in de theologie te Utrecht' ' Deze informatie ontleende Sellın aan een noot van $J$ A Worp in diens uitgave van de briefwisseling van Constantijn Huygens Op 12 oktober 1641 schreef namelıjk M Zuerıus Boxhorn aan Huygens 'Wat je over de controverse inzake het hellenistisch onder ogen zult krıgen, daarvan is naar verluıdt Voetıus de auteur' ${ }^{2} H$ ierbij tekende Worp aan 'Voetıus schreef anonym De lingua Hellenistica tegen Heinsıus' Ook in het artıkel over Voetıus in het biografisch woordenboek van Van der Aa wordt onder de geschriften van de Utrechtse theoloog een anoniem werk De lingua Hellenistıca vermeld ${ }^{3}$

In de uitvoerige biografie over Voetıus van A $\mathrm{C}$ Duker evenwel wordt van een studie over het hellenistısch Grieks die Voetıus geschreven zou hebben in het geheel niet gerept ${ }^{4}$ Inderdaad is van een geschrift uit 1641 met de titel De lingua Hellenistıca nergens een spoor te vinden Wat wèl in 1641 verscheen is de anonieme Exercitatio prima de Hellenistis et lingua Helle nistica ad $D$ Heinsium et $C$ Salmasium (Ultrajectıhl, 1641), maar die is niet van Voetıus, zoals blıken zal Het boek is uiterst zeldzaam In openbare biblıotheken in Nederland komt het niet voor, ook niet in de Bibliothèque Natıonale te Parıjs en de Bodleian Lıbrary te Oxford (volgens de gedrukte catalogus van de Bodleian van 1843 - 1851) In de Natıonal Unıon Catalog van de Library of Congress komt het evenmin voor Een mogelıjk uniek exemplaar van de Exercitatio prima bevindt zich echter in de Britısh Library te Londen

Deze anonıeme Exercıtatio prima nu, waarın voor Heınsıus tegen Salmasius partij wordt gekozen (niet andersom, zoals Worp zegt), is precies het werk waarover Salmasius zijn woede luchtte in zijn Funus linguae Hellenisticae sive confutatıo Exercitatıonis de Hellenistis et lingua Hellenistıca (1643), in de veronderstellıng dat de auteur ervan Danıel Heinsius was Het lijdt geen twijfel, of de op Boxhorn teruggaande traditie die een De lingua Hellenistıca van 1641 aan Voetıus toeschrıft, heeft in oorsprong betrekking op

${ }^{1}$ Paul R Sellın, Danzel Heinszus and Stuart England, Leiden/London 1968, p 47 Dezelfde informatie met minder terughoudendherd p 98

2 Const Huygens, Bnefwersselıng, ed J A Worp, III, 's-Gravenhage 1914, p 244 'Quae de Hellenistica controversia leges, Voetium, ut fama est, autorem habent'

${ }^{3}$ A J van der Aa, Brographisch Woordenboek der Nederlanden, dl XIX, 1876, p 300

${ }^{4}$ A C Duker, Gusbertus Voetzus, 3 dln met indexdeel, Leiden 1897/1915 
de in dat jaar te Utrecht verschenen Exercitatio prima de Hellenistis et lingua Hellenistica. Het jaar van verschijnen klopt nauwkeurig en de plaats van uitgave zal de verdenking op de invloedrijke, niet van polemiek afkerige Voetius gericht hebben, die trouwens ook niet geheel en al buiten de publicatie van het boek heeft gestaan, zoals duidelijk zal worden. Als hoogleraar welsprekendheid te Leiden zal Boxhorn zich ook niet nauwkeurig over de achtergronden van de anonieme Utrechtse publicatie hebben kunnen informeren.

De schrijver van de Exercitatio prima was echter niet Voetius, zoals Boxhorn dacht, noch Heinsius, zoals Salmasius meende, maar Martinus Schoockius, de Groningse hoogleraar in de logica en physica. Dat Schoockius de auteur van de Exercitatio prima was, was uiterlijk in 1643 bekend aan de Parijse jurist en geleerde Claude Sarrau. ${ }^{5}$ Schoockius onthulde zijn auteurschap echter tien jaar na dato zelf in zijn Dissertatio politico-historica de bonis, vulgo, ecclesiasticis dictis in genere... (Groningen, Jo. Collen, 1651; in 12-mo). Ook dit werk, niet te verwarren met Schoockius' bekende Liber de bonis vulgo ecclesiasticis dictis van hetzelfde jaar (1651), is uitermate zeldzaam geworden. Het enige mij bekende exemplaar bevindt zich in de Universiteitsbibliotheek te Utrecht. In de Dissertatio vertelt Schoockius, dat hij in 1640 te Deventer, waar hij toen doceerde aan de Illustere School, in particuliere kring over de lingua Hellenistica en over zekere plaatsen in het Nieuwe Testament had gehandeld. De aantekeningen die hij voor zijn voordrachten had gemaakt oogstten veel instemming bij de geleerden die ze lazen. Daarom legde hij ze in juli 1641, toen hij inmiddels professor in Groningen was geworden, tijdens een bezoek aan Utrecht voor aan Voetius. Deze was er enthousiast over en liet ze na Schoockius' vertrek op eigen initiatief en zonder er Schoockius in te kennen drukken, hoewel de aantekeningen nog niet behoorlijk geredigeerd en voor de pers gereed gemaakt waren. Toen het boek in 1641 was verschenen en een zeer heftig tegenoffensief had uitgelokt in de vorm van de Funus van Salmasius, die er Heinsius voor verantwoordelijk hield, zette Schoockius een nieuw werk op stapel om Heinsius van de ongerechtvaardigde verdenking en blaam te zuiveren en Salmasius van het bestaan van de lingua Hellenistica te overtuigen. Doch dit werk was nauwelijks in handschrift voltooid, of Schoockius vernam dat tussen Heinsius en Salmasius een wapenstilstand was bewerkstelligd, zodat hij het niet meer opportuun achtte met een nieuwe provocerende publicatie de vrede in gevaar te brengen. Aldus het verhaal van Schoockius.

Niet Voetius dus, maar Schoockius is de auteur van het in 1641 uitgekomen werk over het 'hellenistisch' Grieks. De door Boxhorn en Salmasius gewekte misverstanden omtrent het auteurschap van dit werk, de Exercitatio prima, zijn besproken en recht gezet door Thomas Crenius in

5 Zie J. A. H. Bots e.a., De brief als spiegel van een tijdperk (tentoonstellingscatalogus), Nijmegen 1978, p. 18. Sarrau schreef in een brief aan Rivet van 10 oktober 1643 naar aanleiding van de Funus waarin Salmasius zeer fel de Prima exercitatio van Schoockius bestreed: 'Si Schooc n'est pas bien tué et qu'il se releve après les rudes secousses qu'il a receues sous le nom d'Heins, ie plains bien son sort d'avoir une vie si dure'. 
$1708{ }^{6}$ Diens uiteenzettıng is reeds door Ter Horst aangehaald en benut in zijn dissertatie over Heınsius van $1934^{7}$ De inlichtingen van Ter Horst zouden Sellin zijn fout hebben kunnen besparen Thans echter is hernieuwde correctie van overgeleverde misvattingen nodig

Correctie is te meer nodig, wanneer men ziet welk nieuw en ongekend hoogtepunt verwarring, misverstand en slordigheid bij Sellın bereiken $\mathrm{Na}$ zijn vermeldıng van Voetıus' vermeende, boven weerlegde auteurschap van een De lingua Hellenistıca van 1641, maakt Sellin acht regels verder onverstoorbaar meldıng van een anonieme Exercitatıo de lingua Hellenıstıca et de Hellenistıs, verschenen te Leiden in 1643, waarın Heinsius' positie tegen Salmasıus zou zijn verdedigd De auteur die zijn naam verzweeg was, volgens Sellın, 'Martınus Schoockıus, another Professor of Theology at Utrecht' Een boek beantwoordend aan de hier verstrekte bibliografische gegevens zoekt men opnieuw volkomen tevergeefs Gedoeld wordt kennelijk op Schoockius' boven besproken Exercıtatıo prima van 1641, maar Sellın heeft dat werk niet gezien en dateert het met 18de-eeuwse bibliografen als Fabricius ${ }^{8}$ en Morhofius ${ }^{9}$ ten onrechte in 1643, zodat hij één en hetzelfde werk eerst in 1641 als van Voetius en vervolgens in 1643 als van Schoockıus presenteert $\mathrm{H}_{\mathbf{l}}$ geeft nıet alleen de tıtel, alsmede plaats en jaar van uitgave verkeerd, maar bovendıen Schoockıus' functie (hij was geen hoogleraar theologie, maar doceerde logica en physica) en de universiteit waaraan hij verbonden was (niet Utrecht, maar Gronıngen) Een soortgelyjke kluwen fouten treft men aan onder nr 419 van zljn 'Checklıst' van Heinsius' werken ${ }^{10}$ Daar wordt, op grond van Fabricius, dezelfde spookuitgave van een Exercıtatıo de lingua Hellenıstıca E' Hellenıstıs ('Leiden, 1643') eerst op naam van Heinsius gesteld en vervolgens als 'waarschijnlijk' Identıek met Schoockıus' werk van 'dezelfde' (1) titel aangeduıd De chaotısche verwarrıng die Sellın hier stıcht kan niet in het kort worden ontrafeld Slechts zij opgemerkt, dat $\mathrm{m} 1 \mathrm{j}$ geen gegevens bekend zijn die erop wijzen, dat Schoockıus' Exercitatıo prima, bij voorbeeld in een herdruk of bewerking, te Leiden in 1643 zou zıjn verschenen

In de strıd tussen Heinsıus en Salmasius over het 'hellenıstısch' Grieks heeft Voetius zich niet met een eigen geschrift gemengd De anonieme Utrechtse publicatie waarmee in dit geschil in 1641 ten gunste van Heinsius werd ingegrepen is Martinus Schoockıus' Exercitatıo prima de Hellenistis et lingua Hellenistica ad $D$ Heinsium et $C$ Salmasium Deze verscheen te Utrecht in 1641 Op dit ene werk hebben betrekking berichten volgens welke Voetıus in 1641 een werk over de lingua Hellenistıca het licht zou hebben doen zien, alsook mededelingen over een Exercıtatıo over dat onderwerp van Schoockıus uit 1643

6 Th Crenıus, Anımadversionum Phılologıcarum et Historicarum Pars XVI, Lugdunı Batavorum 1708, pp $68-71$

7 D J H ter Horst, Danel Hensius (1580 1655), Utrecht 1934, p 132

${ }^{8}$ Sellın verwijst zelf naar J A Fabricius, Bibliotheca Graeca, 3de uitg, Hamburg 1718/40, dl III, p 226 (zie Checklsst onder nr 419)

${ }^{9}$ D G Morhofius, Polyhistor, Lubeck $1732^{3}$, dl I, p 789

${ }^{10}$ Sellın, Daneel Heinsıus, p 250 


\section{Appendix II. Het oordeel van Van Unnik over Grotius als uitlegger van het Nieuwe Testament}

De belangrijkste 17 de-eeuwse commentaar op het Nieuwe Testament wordt ongetwijfeld gevormd door de Annotationes van Hugo Grotius, waarvan die op de evangeliën werden uitgegeven te Amsterdam in 1641, die op Handelingen en de paulinische brieven posthuum te Parijs in 1646 en die op Openbaring eveneens te Parijs in $1650 .{ }^{1}$ Voor een beoordeling van dit werk wordt binnen Nederland doorgaans verwezen naar het artikel 'Hugo Grotius als uitlegger van het Nieuwe Testament' dat W. C. van Unnik in 1932 deed verschijnen in het Nederlandsch Archief voor Kerkgeschiedenis (N.S. 25). Het feit dat dit, treurig genoeg, inderdaad de enige studie is die in deze eeuw speciaal aan Grotius als nieuwtestamentisch exegeet gewijd is, kan zulke verwijzingen rechtvaardigen. Bedenkingen echter waartoe dit artikel aanleiding geeft worden er zelden tegen ingebracht, zodat de indruk zou kunnen ontstaan, dat Grotius' nieuwtestamentische exegese in Van Unniks verhandeling haar gezaghebbende, klassiek geworden beschrijving en evaluatie gevonden heeft. Zulk een indruk zou niet slechts onjuist zijn, maar wat erger is, ook hernieuwde pogingen tot een analyse van Grotius' exegetisch werk in de weg kunnen staan. Onderstaande opmerkingen willen duidelijk maken, dat het artikel van Van Unnik, hoeveel goeds het ook bevat, niet de definitieve beschrijving van Grotius als exegeet van het Nieuwe Testament kan zijn. Dat pretendeerde het trouwens ook niet.

Vooraf moet worden opgemerkt, dat de studie van Van Unnik over Grotius zeker als een bijzondere prestatie moet gelden: hij schreef haar op twintigjarige leeftijd! Dit in aanmerking nemende, kan men slechts respect hebben voor de kennis en belezenheid waarvan Van Unnik in zijn verhandeling blijk geeft. Voorts moet royaal worden erkend, dat Van Unniks artikel op belangrijke onderdelen werkelijkheid en waarheid juist getroffen of dicht benaderd heeft. Het verslag van de wordingsgeschiedenis van de Annotationes zoals Van Unnik dat geeft (pp. 4 - 16) voldoet ruimschoots, al kan er inmiddels op grond van de aanzienlijk gevorderde uitgave van

1 H. Grotius, Annotationes in libros Evangeliorum. Cum tribus tractatibus et appendice eo spectantibus, Amsterdam, Johannes \& Cornelius Blaeu, 1641. - Annotationum in Novum Testamentum, tomus secundus (ondertitel: Annotationes in Acta Apostolorum, et Epistolas Apostolicas), Parijs, sumptibus authoris, et prostant exemplaria apud Viduam Gulielmi Pelé, 1646. - Annotationum in Novum Testamentum pars tertia ac ultima. Cui subiuncti sunt eiusdem auctoris libri Pro veritate religionis Christianae, Parijs, Typis Viduae Theod. Pepingué \& Steph. Maucroy, 1650. 
Grotius' correspondentie een en ander aan worden verbeterd en gepreciseerd. Zeer juist taxeert Van Unnik ongetwijfeld de impuls die Grotius, althans in zijn latere jaren, tot het schrijven van de Annotationes dreef: zijn kerkelijk irenisme. Hij wilde de Schrift zo verklaren, dat op basis van deze exegese de pax ecclesiae kon worden hersteld. Het had wellicht vermelding verdiend, dat het hier om een opvatting van exegese gaat die in de 16de eeuw reeds door mannen als Erasmus en G. Mercator was gehuldigd; maar het is in elk geval een verdienste dat Van Unnik deze achtergrond in het licht heeft gesteld.

Ook is voor een belangrijk deel het eindoordeel dat Van Unnik over de praktische, wat hij noemt materiële uitlegging van Grotius geeft correct. Als correctief op de voorstelling als zou Van Unnik in zijn stuk hebben aangetoond, dat Grotius niet de belangrijke exegeet is geweest als voor welke hij algemeen gehouden wordt, mogen wellicht enkele regels van Van Unnik zelf geciteerd worden:

“. .. ; materiëel is er bij hem veel te leeren. Door de schatten van kennis over de klassieke, patristische en joodsche litteratuur, die hij de zijne kon noemen en waarvan het voor ons onbegrijpelijk is, hoe hij dit alles kon omvatten, en die hij zoo rijkelijk in zijn Annotationes geeft, hebben zijn verklaringen nog altijd waarde. Bij exegese van den Bijbel zal het goed zijn om naar dit monument, dat zeker wel de belangrijkste verklaring uit de 17 de eeuw is, te zien en van zijn verklaringen kennis te nemen. Vanzelfsprekend zal dan blijken, dat hij meer dan eens het juiste getroffen heeft''. (p. 45).

De verhandeling van Van Unnik verdient kortom om verscheidene redenen instemming en waardering. Er zijn echter ook bezwaren tegen aan te voeren.

Het minst erg zijn misschien de zakelijke vergissingen en gebreken. De paragraaf over Grotius' 'hulpmiddelen' bij voorbeeld is een wat willekeurige en onvolledige vermelding van alleen het voor de hand liggende en het toevallig gevondene. Geen systematische poging wordt ondernomen om vast te stellen, welke rabbinica Grotius heeft gekend en benut. ${ }^{2}$ Dat deze paragraaf niet op toereikende documentatie berust, blijkt uit een mededeling als: 'Grotius ging bij zijn verklaring terug op den Griekschen text en gebruikte, zooals blijkt uit een brief van 1619, in den Loevensteinschen tijd de uitgave van Erpenius'. (p. 16). In een voetnoot hierbij zegt Van Unnik, dat hij een Griekse editie van Erpenius niet heeft kunnen vinden. Maar in Grotius' brief, door Van Unnik zelf geciteerd (p. 5), staat ook niet dat Grotius een editie van Erpenius 'gebruikte', maar dat hij aan het werk was 'om de editie van Erpenius te ornare', d.w.z. toe te rusten, namelijk met verklarende aantekeningen. Het is Van Unnik ontgaan, dat De Groot hier niet doelt op een bestaande editie, maar op het bekende,

${ }^{2}$ Een goede hulp bij een onderzoek van dien aard is nu: A. W. Rosenberg, 'Hugo Grotius as Hebraist', Studia Rosenthaliana 12 (1978), pp. 62 - 90. 
groots opgezette project van Erpenius tot uitgave van een polyglot van het Nieuwe Testament, het zogenaamde Tabernaculum Domini Nostri Jesu Christi. ${ }^{3}$ Aan deze schitterende wetenschappelijke uitgave zou Grotius aantekeningen bijdragen, maar de onderneming leed schipbreuk in de Synode van Dordrecht. De hier gesignaleerde vergissing van Van Unnik is ietwat noodlottig, omdat hem er tevens door ontgaat, dat Grotius voor het schrijven van Annotationes op het Nieuwe Testament in eerste instantie een heel concrete en praktische aanleiding heeft gehad, te weten de door Erpenius geplande polyglot en niet reeds direct gemotiveerd is geweest door irenische of oecumenische oogmerken, zoals Van Unnik doet voorkomen, bij voorbeeld wanneer hij concludeert, 'dat Grotius den Bijbel is gaan uitleggen teneinde daarmee een grondslag te hebben voor de Eenheid der Christelijke kerken' (p. 42).

Wat bedenkelijker is Van Unniks aanvechtbare opvatting, dat Grotius "niet werkte met wat wij tegenwoordig "philologische Kritik und Forschung' noemen"' (p. 44 - 45) en dat hij "geen origineele baanbreker", zou zijn geweest (p. 48). De manier immers waarop Grotius, om een voorbeeld te noemen, op grond van letterkundige observaties de traditionele opvatting betreffende de volgorde van ontstaan van de Thessalonicenzenbrieven kritiseert en die volgorde omkeert en de manier waarop hij II Petrus in de tijd van Trajanus dateert, heeft alle recht op de kwalificatie filologische kritiek. Het zijn werkelijk pogingen tot het oefenen van literair-historische kritiek op filologische grondslag. Filologische kritiek kan men Grotius derhalve geenszins ontzeggen, al past hij deze niet stelselmatig toe. Maar reeds zijn incidentele blijken van een scherp kritische zin in het historische doen Grotius uitrijzen boven zijn tijdgenoten en rechtvaardigen de waardering van zijn exegese als methodisch baanbrekend.

Ernstiger dan zulke feitelijke onnauwkeurigheden is de teleurstellende opzet van Van Unniks artikel als geheel. Hoewel hij zijn studie aandient als een onderzoek over 'Hugo Grotius als uitlegger van het Nieuwe Testament', behandelt hij in werkelijkheid niet Grotius' uitlegging, maar zijn schriftopvatting en uitleggingsprincipes. Deze beschouwt hij vervolgens in de context van Grotius' dogmatische opvattingen omtrent zonde en verlossing. En omdat Van Unnik die opvattingen afwijst, concludeert hij ook: 'Formeel moeten wij Grotius als exegeet afwijzen en heeft hij ons niets meer te zeggen'. (p. 45).

Omdat Van Unnik er tegelijk van doordrongen blijft, dat in de praktijk Grotius' annotaties op het Nieuwe Testament 'de belangrijkste verklaring uit de 17de eeuw' zijn, erkent hij dat er 'materieel veel bij hem te leren valt'. Desondanks houdt Van Unnik vol: 'Wij meenen Grotius als exegeet zooals hij zichzelf zag te moeten afwijzen'. (p. 48). Het is alsof iemand die een goede sigaar krijgt aangeboden antwoordt: 'Nee, dank $u$, die sigaar vind ik heerlijk, maar de tabak ervan niet'.

${ }^{3}$ Hierover zie men nu Th. H. Lunsingh Scheurleer ed., Leiden University in the Seventeenth Century, p. 70 en p. 209, behalve de betreffende passages in W. M. C. Juynboll, Zeventiendeeeuwsche beoefenaars van het Arabisch in Nederland, Utrecht 1931, pp. 86 - 89. 
Over de omtrekkende beweging waarmee Van Unnik tevergeefs gepoogd heeft zijn doel te bereiken zou veel te zeggen zijn.

Ten eerste, dat Grotius' theologie, schriftopvatting en hermeneutiek niet aan de orde waren, maar zijn exegese, waarop Van Unnik niet werkelijk ingaat. De samenhang tussen dogmatische vooronderstellingen en exegese behoeft niet te worden ontkend, maar het zou nu eenmaal over de uitlegging gaan en daar komt Van Unnik nauwelijks aan toe.

Ten tweede, indien een kerkhistoricus al over Grotius' theologie wil schrijven, dan nog ware het niet nodig daarover te richten in termen als 'religieus tekort geschoten', 'niet reformatorisch', 'afwijzen'. Historische beoordeling behoeft toch niet uit te lopen op aannemen of afwijzen. Is het geen fictie te menen, dat er überhaupt enige enigszins uitgewerkte theologie of filosofie is die nog na drie eeuwen door een bedachtzaam historicus zou kunnen worden aanvaard? Zo'n aanvaarding zou een miskenning zijn van de tijdgebondenheid van elke wat ontwikkelde theologie en in zoverre ware de onderschrijving van een driehonderd jaar oude theologie zelfbedrog. Waarom dan Grotius als theoloog en exegeet met zoveel nadruk 'afgewezen'? Niet dat zulk een oordeel nogal hard is - aan jeugdig élan moet men wat toestaan en menigeen herleest verbaasd zijn wat sportief uitgevallen kwalificaties van weleer. Maar zo'n scherpe afwijzing is na drie eeuwen zinloos, omdat Grotius geen 20ste-eeuwse mensen voor theologische beslissingen stelt. Voor aannemen of afwijzen is de tijd al lang voorbij. De historicus die zich dit realiseert zal zich in zijn oordeel matigen.

Ten derde, de maatstaven die Van Unnik de theoloog Grotius aanlegt zijn van dogmatische aard. Dat zou niet geven als niet ontmoedigend veel mensen met even veel recht andere dogmatische criteria kunnen hanteren. Van Unnik is van oordeel, dat Grotius 'de eigenlijke kern van het Nieuwe Testament niet begrepen heeft' ( $p .41$ ) en dat 'de kern van het christelijk geloof ... hem verborgen is gebleven' (p. 39). Maar wie maakt uit, wat de eigenlijke kern van het Nieuwe Testament en wat de kern van het christelijk geloof is? Wat heeft het, gezien het feit dat daarover oneindig veel even legitieme zienswijzen kunnen bestaan, voor zin, de theoloog Grotius zo krachtig te veroordelen als Van Unnik doet? Juist de dogmatische aard van Van Unniks criteria en hun daarmee gegeven betwistbaarheid hadden hem tot meer terughoudendheid moeten stemmen.

Het valt te betreuren, dat Van Unnik bij dit alles erover zwijgt:

1. hoe eindeloos ver de commentaren van 17 de-eeuwse theologen in praktische waarde bij Grotius' aantekeningen ten achter staan;

2. hoe veel meer verzen en woorden van het Nieuwe Testament Grotius van toelichting voorziet dan wie ook van de annotatores van zijn tijd en hoeveel nuttiger zijn commentaar daardoor is;

3. of er enige 17 de-eeuwse commentator is wiens theologische opvattingen wèl Van Unniks goedkeuring kunnen wegdragen en die daardoor een goede commentaar, die nog na drie eeuwen bruikbaar is, heeft geschreven.

Aangezien Van Unnik zelf Grotius' Annotationes de beste verklaring van 
het Nieuwe Testament uit de 17 de eeuw noemt, na eerst 'Grotius als exegeet' te hebben afgewezen, is de conclusie onontwijkbaar, dat voor de evaluatie van Grotius' verklaring van het Nieuwe Testament een beoordeling van hem 'als exegeet' zoals Van Unnik die geeft, uiteindelijk overbodig is.

De slotsom moet zijn, dat Van Unnik vooral door de wijze waarop hij zijn taak ten uitvoer legt haar niet vervult. Ten onrechte ontkent hij, dat Grotius filologische kritiek heeft beoefend. Hij constateert wel, dat Grotius' schriftverklaring materieel de beste van haar tijd was, maar demonstreert dit niet. In plaats daarvan behandelt hij Grotius' schriftopvatting en andere theologische concepties en wijst die af. Deze beoordeling is weinig ter zake en, gebaseerd als ze is op aanvechtbare vooronderstellingen, te ver gedreven. Als studie over 'Hugo Grotius als uitlegger van het Nieuwe Testament' heeft Van Unniks artikel daarom zijn doel niet bereikt. Het bevat intussen veel deugdelijk materiaal dat een hernieuwde poging ten goede kan komen. ${ }^{4}$

Het mag hier niet onvermeld blijven, dat Van Unnik later op velerlei manieren, als auteur, als redacteur, als inspirator en begeleider van onderzoek van anderen, een levendige interesse is blijven tonen in de geschiedenis der nieuwtestamentische wetenschap. De verdiensten die Van Unnik ook voor deze tak van onderzoek heeft, staan niet toe, over zijn jeugdwerk betreffende Grotius anders te spreken dan met eerbied en erkentelijkheid.

\footnotetext{
4 Het artikel is onlangs herdrukt in de bundel Woorden gaan leven. Opstellen wan en over
} W. C. van Unnik (1910-1978), Kampen 1979, pp. $172-214$. 


\section{Appendix III. De noten op het Nieuwe Testament van Josephus Scaliger}

In de jaren van ongeveer 1585 tot 1605 is er zowel vanuit Frankrijk als uit Nederland door verscheidene geleerden druk op Scaliger uitgeoefend om hem te bewegen tot het publiceren van aantekenıngen op het Nieuwe Testament Vastberaden en stelselmatig heeft hij dit geweigerd $\mathrm{H}_{1 j}$ was bevreesd, dat zijn kritische opvattingen een onwelwillend onthaal zouden vinden, met name van katholıeke zijde en repercussies zouden uitlokken die hem zouden nopen te reageren, waardoor hy belemmerd zou worden in de realıserıng van de grote wetenschappelijke projecten waaraan hij met onvoorstelbare energie werkte $\mathrm{Na}$ Scalıgers dood (1609) z1jn echter verscheidene series noten op het Nieuwe Testament onder zun naam gepubliceerd en in handschriften als van zijn hand afkomstig gesignaleerd Omtrent de authenticiteit daarvan is soms twijfel geuit De overleveringsgeschiedenıs van Scalıgers noten op het Nieuwe Testament heb lk elders enıgszins uitvoerıg behandeld ${ }^{1}$ Deze geschiedenis is ten dele gecompl1ceerd Het is daarom wellicht dienstig, hier de sets noten die Scaligers naam dragen nogmaals op te sommen en per geval in het kort aan te geven, welke aanspraak op authentıciteit zlj kunnen doen gelden

\section{De Genevensia}

Voor het eerst verschenen noten van Scaliger op het Nieuwe Testament als onderdeel van een Grieks Novum Iesu Christı $D N$ Testamentum, gedrukt en uitgegeven door Petrus de la Rovière te Genève in 1619 Dezelfde editie werd in 1620 met een gewijzigd titelblad en in hetzelfde jaar nog eens met een nieuw titelblad uitgebracht De noten, die soms voorin, soms achterin zijn gebonden, worden ingeleid met enkele regels ('Exhıbemus tıbı, Lector '), waarin de lezer wordt verzocht, verdere noten van Scalıger waarover hij mocht beschikken in het licht te geven De aantekeningen zelf bestaan ut twee reeksen, elk gerangschıkt naar de volgorde van de boeken van het Nieuwe Testament De eerste serie bevat korte noten op 23 plaatsen van Mt 1711 tot I Petrus 46 Daarop volgt de tweede serie, die lange aantekeningen en excursen bevat op I Cor 315 (niet op volgorde), Mt 611 en andere plaatsen, waarvan de laatste Openb 175 is

De oorsprong van deze aantekenıngen is de volgende

${ }^{1}$ In $\mathrm{Th} \mathrm{H}$ Lunsingh Scheurleer (e a, edd ), Leiden University in the Seventeenth Century An Exchange of Learning Leiden 1975, zue pp 7882 
De eerste serie, bestaande uit de korte noten, is een selectie uit een verzameling opmerkingen over het Nieuwe Testament welke voorkomt in het MS. Parijs, Bibliothèque Nationale, Dupuy 395, II, fol. 21r. - 22r. Deze verzameling is in het MS. ondertekend met 'Jos. Scal. Jul. Caes. f.' Hoewel het MS. zelf niet autograaf is, kan blijkens het onderschrift en bepaalde voor Scaliger kenmerkende noten deze eerste serie van (wat ik gemakshalve noem) de Genevensia zonder meer als authentiek worden beschouwd. Slechts moet dit voorbehoud worden gemaakt, dat de noten in hun gedrukte vorm niet slechts minder talrijk zijn dan in het genoemde MS., maar voor zover ze gedrukt zijn her en der ook ingekort zijn. Het MS. biedt een betere tekst dan de edities, hieronder opgesomd.

De langere noten en excursen, die het tweede deel van de in 1619 gedrukte serie vormen, komen ten dele voor in Scaligers eigen hand in hetzelfde MS. Dupuy 395, II, fol. 2r. - 5v., aldaar besloten met de woorden van Scaliger zelf: 'A Dieu Monsieur. Ie vous baise les mains ce 30 Juillet 1591'; deels staan ze onder Scaligers naam, maar in iemand anders hand op fol. 16r. - v. en 21r. van hetzelfde MS. Voor nog weer een ander deel zijn deze uiteenzettingen in sterk overeenkomende vorm bewaard in overgeleverde en gedrukte brieven van Scaliger. De authenticiteit van de tweede set noten staat daarom eveneens vast, maar ook hun tekstvorm is meestal bekort.

De Genevensia zijn kortom ongetwijfeld van Scaliger, maar hun aantal zou uit de bronnen waaruit zij stammen kunnen worden vermeerderd en hun tekst moet verbeterd worden met behulp van MS. Dupuy 395, II, fol. 2r. - 22r. en van Scaligers correspondentie. De noten stammen uit Scaligers Franse tijd, d.w.z. van voor 1593 en zijn nooit voor publicatie bestemd geweest, maar bij verschillende gelegenheden als vluchtige notities voor vrienden op papier gezet. Vermoedelijk heeft François Vertunien, een vriend van Scaliger, ze oorspronkelijk verzameld. Aan hem heeft Scaliger althans een stel noten op het Nieuwe Testament beschikbaar gesteld dat nu in MS. Dupuy 395, II voorkomt op fol. 19r. -22r. en waarvan één noot, op Mt. 6:11, deel uitmaakt van de Genevensia. Maar voor de publicatie van de Genevensia kan Vertunien, die in 1607 stierf, niet verantwoordelijk zijn. Wie dan wel, is onbekend.

De Genevensia werden na voor het eerst te zijn uitgegeven in 1619 en 1620 door De la Rovière, opnieuw afgedrukt als bijlage bij de volgende edities van het Griekse Nieuwe Testament:

London 1622 (Billius);

London 1633 (Whittaker, gedrukt door de Elzeviers te Leiden);

Leiden 1641 (Elzevier).

Vervolgens verschenen ze in de drie uitgaven van de Critici Sacri (London 1660, Frankfurt 1695, Amsterdam 1698), terwijl excerpten in andere exegetische verzamelwerken verschenen. De eerste reeks Genevensia, de korte noten, vindt men ook in het MS. Parijs, Bibliothèque Nationale, lat. 17,283, fol. 4r. - 11v., een 18de-eeuws afschrift van het Dupuyhandschrift. 


\section{De Vinariensia}

Met deze benaming duid ik de noten aan die onder de titel 'Scaligeri Animadversiones MSS. in Bezae Novum Testamentum' zijn gepubliceerd door H. L. Schurzfleisch in zijn Acta Literaria, Vitembergae 1714, pp. 23 33. Het zijn korte kritische opmerkingen waarmee Scaliger reageerde op Beza's folio-uitgave van het Nieuwe Testament met commentaar van 1582. Al lezende noteerde Scaliger in de marges zijn kritiek op Beza. Het door Scaliger zelf geannoteerde exemplaar bevond zich in de 18de eeuw in de Hertogelijke Bibliotheek te Weimar en Schurzfleisch publiceerde uit dat exemplaar, dat Scaliger zelf gebruikt had, de marginalia. Ook nu nog is het bewuste boek in de Zentralbibliothek der deutschen Klassik te Weimar (signatuur: $2^{\circ} \mathrm{Cl}, 1: 32$ ). De aantekeningen van Scaliger zijn, vermoedelijk in de bibliotheek van G. J. Vossius waarin het boek na Scaligers dood terecht kwam, uit Scaligers exemplaar overgeschreven in een ander exemplaar van Beza 1582 dat tegelijkertijd in G. J. Vossius' bibliotheek berustte en dat nu in de Leidse universiteitsbibliotheek wordt bewaard (525 A 3).

De gedrukte Vinariensia zijn dus authentiek, maar ze geven niet aan, waar Scaliger op Beza reageerde door het aanbrengen van onderstrepingen en pijlen en ook overigens biedt de liber annotatus zelf iets meer aantekeningen dan Schurzfleisch publiceerde.

Uit Scaligers correspondentie blijkt, dat hij zijn noten op Beza's Nieuwe Testament schreef in de jaren 1584 - 1586. Daar zal hij later mogelijk nog wel eens iets aan toegevoegd hebben, maar in hoofdzaak dateren ook de Vinariensia uit zijn Franse tijd.

\section{De Annotationes in Matthaei evangelium}

Het MS. Parijs, Bibliothèque Nationale, lat. 690 bevat een uitlegging van een Hebreeuws Matthaeus-evangelie, hoofdstuk 1 tot 11. Volgens de catalogus is het MS. 'de la main de Joseph Scaliger'. Dit is juist, maar ten onrechte heb ik het geschrift in kwestie voorheen aangezien voor een jeugdwerk van Scaliger. Het is geen werk van Scaliger, maar een door hem neergeschreven collegedictaat van de lessen van een hoogleraar Hebreeuws die onlangs Genesis had behandeld en nu een Hebreeuwse tekst van Matthaeus ging lezen, waarschijnlijk die uitgegeven door J. Mercerus, Parisiis 1555. In de inleiding zegt de auteur, dat hij 'na de lezing van Genesis', post Geneseos lectionem, meent dat met recht 'iets uit het Nieuwe Testament aan U wordt voorgelegd', Novi Testamenti aliquid vobis proponi. Hij twijfelt niet of lezing van Matthaeus in het Hebreeuws is van nut 'voor hetgeen wij zoeken, namelijk de kennis van het Hebreeuws', ad id quod quaerimus, id est, ad Hebraicae linguae cognitionem. De terminologie (lectio, proponere, etc.) is, wat ik destijds niet goed gezien heb, die van de collegezaal. Maar Scaliger heeft nooit Hebreeuws gedoceerd. Hij kan daarom van dit werk onmogelijk de auteur zijn. 


\section{Opmerkingen betreffende het Nieuwe Testament in de Scaligerana}

De Scaligerana, die talrijke hoogst belangwekkende opmerkingen over het Nieuwe Testament bevatten naast mededelingen over allerlei andere onderwerpen, vallen uiteen in de Prima Scaligerana en de Secunda Scaligerana.

De Prima Scaligerana zijn uitlatingen van Scaliger en excerpten uit zijn brieven daterende uit de periode 1574 tot 1593. Ze zijn verzameld en geredigeerd door Scaligers goede vriend François Vertunien. Deze had als huisarts van de familie Rochepozay, bij welke Scaliger twintig jaar onderdak en gelegenheid tot wetenschappelijke arbeid vond, veel contact met Scaliger. Uit gesprekken en brieven bracht hij een aantal mededelingen en uitlatingen van Scaliger bijeen. Deze collectie werd eerst in 1669 uitgegeven door Tanaquil Faber te Saumur; op de titelpagina werd veiligheidshalve 'Groningae' als plaats van uitgave vermeld. Wat de authenticiteit van deze Prima Scaligerana betreft, de opvattingen zijn ongetwijfeld die van Scaliger, voor de formulering is ten dele de redacteur Vertunien verantwoordelijk.

De Secunda Scaligerana zijn notities die twee studenten, de gebroeders De Vassan, van 1603 tot 1606 maakten naar aanleiding van hun ontmoetingen met Scaliger, die toen te Leiden aan de Breestraat, recht tegenover het stadhuis (nu nrs. 111 - 113), resideerde. De beste editie van deze Secunda Scaligerana is die van Joh. Dallaeus, te Rouen in 1667 uitgebracht met als valse plaats van uitgave 'Coloniae Agrippinae'. Dallaeus heeft de volgorde van de gesprekken opgelost en het materiaal alfabetisch op onderwerpen gerangschikt.

De Prima en Secunda Scaligerana zijn tenslotte naar de edities van Faber en Dallaeus tesamen uitgegeven door P. des Maizeaux te Amsterdam in 1740. Dit is de bruikbaarste editie, die, zolang er geen kritische editie van de Scaligerana is, zou verdienen gereprint te worden.

In het algemeen geven ook de Secunda Scaligerana de opvattingen van Scaliger betrouwbaar weer. Dat blijkt uit de talloze overeenstemmingen tussen deze Scaligerana en Scaligers gedrukte werken en brieven. Het is echter niet geheel uitgesloten, dat de gebroeders De Vassan de uitlatingen van hun leermeester een enkele keer niet volkomen correct hebben begrepen en weergegeven. De juistheid van bij voorbeeld hun mededeling, dat Scaliger een Biblia Samaritana zou bezitten (Des Maizeaux, pp. 544 en 550) is aan twijfel onderhevig, omdat Scaliger althans geen Samaritaanse Pentateuch bezat, maar het in het Arabisch gestelde, doch met Samaritaanse karakters geschreven boek Jozua, een kroniek gebaseerd op het kanonieke boek Jozua, thans in de Leidse universiteitsbibliotheek (Or. 249). Maar tot zulke twijfels bestaat slechts hoogst zelden aanleiding. Wat meer voorzichtigheid is geboden ten aanzien van de authenticiteit van de precieze formulering. De gebroeders De Vassan maakten hun verslag van wat Scaliger hun zei ongetwijfeld steeds pas na afloop van hun ontmoetingen met de geleerde: indien ze in zijn bijzijn notities hadden gemaakt, dan zou hij heel wat minder vrijmoedig zijn geweest. Zij noteerden Scaligers woorden dus uit hun geheugen. Nu kunnen ze hun best hebben 
gedaan om Scaligers uitspraken getrouw weer te geven en doordat ze met hun tweeën waren er beter in geslaagd zijn, de authentieke formuleringen vast te leggen dan wanneer slechts één hoorder het onderwijs van Scaliger na enkele uren had moeten verslaan. Niettemin moet men wel aannemen, dat Scaliger niet voor elk detail van de formulering zoals zij nu luidt verantwoordelijk kan worden gehouden. Men moet er rekening mee houden, dat in sommige gevallen de bondigheid van de formulering niet die van Scaliger behoeft te zijn, maar de concisie kan zijn waarmee zijn woorden achteraf vlug werden geboekstaafd. Overigens bediende Scaliger zich in zijn brieven en wetenschappelijk proza ook zelf van een uiterst geserreerde taal.

In de beide complexen Scaligerana heeft men, kortom, vrijwel zonder uitzondering de ideeën, zienswijzen, opmerkingen en observaties van Scaliger. In de formulering moet men echter veelal de mogelijkheid van een niet-authentiek redactioneel element open laten. Dit redactionele element kan men slechts afwezig achten, waar een overeenstemmende formulering in Scaligers eigen geschriften de authenticiteit van een uitdrukking in de Scaligerana waarborgt, of waar in de Prima Scaligerana zeker is dat een fragment uit een brief afkomstig is. 


\section{Appendix IV. Een officieel standpunt van de Leidse theologische faculteit inzake de aard van het Nieuwtestamentisch Grieks (1637)}

Op 26 mei 1637 tekenden alle vier de professoren van de theologische faculteit te Leiden, alsmede de hoogleraar Hebreeuws C. L'Empereur en de oriëntalist L. de Dieu, Regent van het Waalse College, een getuigschrift ten gunste van zekere Duitser Samuel Heucherius. De ondertekenaars verklaarden in het testimonium, dat Heucherius' lexicografische werkzaamheden op het gebied van het Hebreeuws van groot belang waren en dat betrokkene daarom in aanmerking verdiende te komen voor geldelijke ondersteuning. ${ }^{1}$

Het document, dat nog niet is gepubliceerd, bevat een korte, maar interessante passage waarin de Leidse theologen en oriëntalisten zich gezamenlijk over de aard van het Nieuwtestamentisch Grieks uitlaten. Acht jaar nadat Sebastian Pfochen, leerling van Georg Pasor te Franeker, in zijn Diatribe de linguae graecae Novi Testamenti puritate (Amsterdam, 1629) had betoogd, dat in het Nieuwe Testament geen hebraïsmen voorkomen, namen de Leidse geleerden onbevangen het 'hebraïstische' standpunt in, dat het Nieuwe Testament op elke bladzijde verscheidene Hebreeuwse wendingen, zij het in Griekse woorden, bevat. Het testimonium zegt: 'Boven alle overige talen heeft het Hebreeuws de ereplaats, daar hierin meer uitspraken Gods voorkomen, dan in enige andere taal. En wat het Grieks van het Nieuwe Testament betreft, er komt daar geen bladzijde in voor, of ze bevat verscheidene Hebreeuwse wendingen (phrases), zij het ook in Griekse woorden (voces)'.

De laatst geciteerde zin werd natuurlijk geschreven ter aanbeveling van bepaalde Hebreeuwse studiën; men mag er daarom niet een opzettelijke, uitdrukkelijke stellingname in de hebraïstisch-puristische controverse, waartoe Pfochen's Diatribe de inleiding vormde, in lezen. Maar de zin over het Nieuwe Testament zou, zonder veel nadeel voor het ten behoeve van een hebraicus uitgeschreven testimonium, even goed achterwege gelaten hebben kunnen zijn. Het is daarom toch opmerkelijk te zien, dat de zes gezaghebbende ondertekenaars zich spontaan verenigen op het standpunt, dat het Nieuwe Testament onder het gewaad van Griekse woorden (voces) veel Hebreeuwse wendingen (phrases) bevat. Met Hebreeuwse phrases

1 Testimonium van J. Polyander e.a. voor Samuel Heucherius, origineel MS. te München, Bayerische Staatsbibliothek, Cod. Lat. 10.415, folia 203 r. - 204 r. Ik dank Dr A. J. Lamping (Leiden) die mij op dit document opmerkzaam maakte. Het stuk is in Polyanders handschrift. 
wordt hier ongetwijfeld gedoeld op uitdrukkingen waarvan mogelijk bepaalde uiterlijke kenmerken, maar in elk geval de betekenis en connotaties ontleend zijn aan equivalenten in het Hebreeuws. Hugo Grotius beschreef het verschijnsel korte tijd later in zijn aantekeningen op Mt. 11:21 in klare termen: 'Griekstalige joden gebruikten ook in het Grieks een Hebreeuws woord in zijn Hebreeuwse betekenis' (Hellenistae Hebraeam vocem sensu Hebraico usurparunt etzam in Graeco sermone)

Het in het testimonıum voor Heucherius neergelegde standpunt inzake het Grieks van het Nieuwe Testament is niet uitzonderlijk; van de meeste ondertekenaars kan men gemakkelijk uitlatingen vinden, die doen blijken dat $z 1 j$ individueel genoemd standpunt toegedaan waren. Het belangwekkende is hier, dat de theologische hoogleraren tesamen, met de hebraicus en de Regent van één der theologische collegia, een gezamenlijk en min of meer officieel standpunt innamen. Overigens had de theologische faculteit te Leiden al in 1625 een soortgelijk officıeel standpunt over het Grieks van het Nieuwe Testament kenbaar gemaakt in de Synopsis purnoris theologıae (III, 10). Hier heet in een disputatie geschreven door Ant. Thysius de taal van het Nieuwe Testament, afgezien van Hebreeuwse en Aramese woorden die er in voorkomen. Grieks zoals 'in Oost en West gangbaar was, maar van een stijl die deels vulgair, deels Hebraeo-grieks is, als gebruikt door Griekstalige joden'.2

Het begin en het slot van het aanbevelingsschrijven voor Heucherius luiden in het, soms ietwat bedenkelijke Latijn (quod concerntt in de zin van 'wat betreft'!) aldus:

'Prae reliquis linguis palmam obtinet Hebraea: quandoquidem non datur alia, quae plura De1 eloquia continet. Et quod Graecam Novi Testamenti concernit, nulla ıbi pagına, quin plures phrases Ebraeas contineat, vocibus licet Graecis. (...)

Lugduni Batavorum, 7 Cal. Jun.,

Anno partae salutis 1637 .

Johannes Polyander, Antonius Thysius, Antonius Walaeus, Jacobus Triglandus, Constantinus L'Empereur, Ludovicus de Dieu' 3

\footnotetext{
2. Graece fere reddita, quod ea lingua tunc Orientı et Occidentı communıssima esset, Gic pro Archia poeta stylo tamen partım vulgarı, partım Hebraeo-graeco, Hellenıstıs Judaeis usitato' Zie Joh Polyander et al, Synopsis puriorts theologiae, 6de ed, ed H Bavınck, Leiden 1881, p 19

${ }^{3}$ De zienswijze die de ondertekenaars hier onderschreven was, het zij nog eens beklemtoond, geenszins gewaagd en toenmaals heel gangbaar Met enig recht kon Salmasıus zes jaar later schrijven 'Semper inter omnes constitıt, verba [Novı Testamentı] esse Graeca, phrasım Hebraicam' (Reeds geciteerd door Ros, De studie van het bybelgneksch, p 60)
} 


\section{Summary. The Study of the New Testament in Dutch Universities and the Armenian Seminary, 1575-1700}

The chronological limits of this study are the foundation of the oldest Dutch university at Leiden in 1575 and the appearance of J. Clericus' main works on the New Testament at Amsterdam about 1700. During this period, universities including theological faculties were established, besides that at Leiden, also at Franeker (1585), Groningen (1614), Utrecht (1636) and Harderwijk (1648), as well as an Arminian Seminary at Amsterdam (1634). In these protestant institutions serious efforts were made to make Scripture alone (sola scriptura) the basis of theology; consequently, the study of the Bible played an important role in them. At the same time, however, biblical exegesis was strongly dominated by dogmatic conceptions and objectives. Valuable contributions to the textual criticism, the grammatical clarification, and the historical understanding of the New Testament were also present, but were largely due to the broad historical and linguistic interest and knowledge on the part of representatives of the arts faculties: historians as Scaliger, Heinsius, Salmasius and Perizonius at Leiden, hebraists as Drusius at Franeker and Braun at Groningen, orientalists as Erpenius and De Dieu at Leiden and Leusden at Utrecht, and Greek scholars as Pasor and Bos at Franeker - apart from such eminent critics as the Arminian theologians Curcellaeus and Clericus at Amsterdam.

The history of New Testament scholarship in Dutch universities and the Arminian College before 1700 can well be described in terms of tradition and innovation. Tradition showed its vitality in an exegesis conditioned by dogmatic theology, in the prominence of the textus receptus, in the ingrained desire to treat the Gospels as historical narratives capable of being harmonised. Innovation made itself felt in efforts to collect variant readings, in the attention devoted to the grammar of New Testament Greek, in the publication and study of ancient translations, and above all in the illumination of the New Testament by means of comparison with ancient Jewish, pagan and patristic sources. 


\section{Bibliografie}

Deze bibliografie vermeldt alleen studies waarin de nieuwtestamentische wetenschap van de $16 \mathrm{de}$ en $17 \mathrm{de}$ eeuw aan de orde komt of, gezien hun chronologisch bestek, had moeten komen. Niet opgenomen zijn encyclopedie-artikelen en de talrijke studies die over slechts één geleerde, één universiteit, of één schriftgedeelte handelen. Bij de meeste titels geef ik enige toelichting of appreciatie.

\section{Geschiedenis der exegese en der bijbelwetenschap in het algemeen}

R. Simon, Historre critique des principaux commentateurs du Nouveau Testament, Rotterdam 1693.

Klassiek.

Philologus atque theologus quidam Germanus (anonymus), 'Praefatio ... in Synopsin Criticorum...', in: M. Polus, Synopsis Criticorum aliorumque Sacrae Scripturae interpretum, 5 dln, Francofurti ad Moenum 1694 ' , I, in het

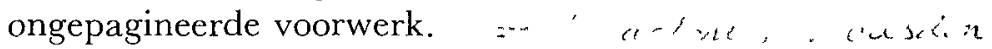

De auteur geeft in $20 \mathrm{blzz}$. een lijst met beoordelingen van de $120 \mathrm{z}$.i. voornaamste exegeten van Europa van alle confessies in de $16 \mathrm{de}$ en $17 \mathrm{de}$ eeuw. In deze laat 17 de-eeuwse lijst springt de grote rol van de Noordnederlanders in het oog.

G. W. Meyer, Geschichte der Schrifterkläung seit der Widerherstellung der Wissenschaften, 5 dln, Göttingen 1802 - 1809.

Een zeer knap boek: verrassend volledig, goed georganiseerd en doorgaans met merkwaardig juiste, hoewel goedhartige beoordelingen. Misschien het beste, zij het nu verouderde, overzicht van de bijbelwetenschap in de 16de tot 18 de eeuw.

A. Hilgenfeld, Der Kanon und die Kritik des Neuen Testaments in ihrer geschichtlichen Ausbildung und Gestaltung, Halle 1863. Niet gezien.

F. W. Farrar, History of Interpretation, London 1886.

Biedt in een hoofdstuk 'Post-Reformation Epoch' een goede karakteristiek van het voor de wetenschap ongunstige klimaat in het 17 de-eeuwse protestantisme. Gaat meer in op de theologische stromingen dan op de verrichtingen der exegeten zelf, die veelal slechts worden genoemd. Groed geïformeerd. 
Ed. Reuss, Die Geschichte der Heiligen Schriften Neuen Testaments, Braunschweig $1887^{6}$, vooral 'Fünftes Buch. Geschichte der Exegese', pp. $574-679$.

Bijzonder instructief door grote rijkdom aan materiaal en bibliografische gegevens, overzichtelijkheid en veelal rake hoewel zeer korte beoordelingen. Signaleert meer dan het beschrijft.

R. M. Grant, The Bible in the Church. A Short History of Interpretation, New York 1948. Revised edition: A Short History of the Interpretation of the Bible, New York 1965.

Teleurstellend beknopt. Voor de 17de eeuw onbruikbaar. Noemt zelfs Grotius, Clericus en Wettstein niet.

W. F. Howard, The Romance of New Testament Scholarship, London 1949. Biografisch gestoffeerd stemmingsbeeld van vooral de Engelse 19de- en 20ste-eeuwse nieuwtestamentische wetenschap; de periode echter van Hiëronymus tot F.C. Baur wordt in de volgende zin beschreven: 'For fourteen centuries the critical study of the New Testament runs into a tunnel' (p. 33).

W. G. Kümmel, Das Neue Testament. Geschichte der Erforschung seiner Probleme, Freiburg 1958, $1970^{2}$.

Zie ons voorwoord.

J. D. Wood, The Interpretation of the Bible. A Historical Introduction, London 1958.

Geheel als boven bij Grant.

B. Hall, 'Biblical Scholarship: Editions and Commentaries', in: S. L. Greenslade ed., The Cambridge History of the Bible, III, Cambridge 1963, pp. 38 - 93.

Hoofdzaken uit de 16 de eeuw, maar haast niets over de $17 \mathrm{de}$.

D. R. Jones, 'Aids to the Study of the Bible: a selective historical account of the major grammars, lexicons, concordances, dictionaries,...' en 'Commentaries: a historical note', in: S. L. Greenslade ed., The Cambridge History of the Bible, III, Cambridge 1963, pp. 520 - 535.

Nuttig.

D. E. Nineham ed., The Church's Use of the Bible, Past and Present, London (S.P.C.K.) 1963.

Niet gezien.

K. Scholder, Ursprünge und Probleme der Bibelkritik im 17. Jahrhundert

(Forschungen zur Geschichte und Lehre des Protestantismus 10,33), München 1966.

Beschrijft meer de ondergang van het Schriftgezag dan de geschiedenis der exegese.

V. P. Furnish, 'The Historical Criticism of the New Testament. A Survey of Origins', The Bulletin of the John Ryland University Library 56 (1973/4), pp. $336-370$. 
Kent rets te veel gewicht toe aan wijsgerige, iets te weinig aan filologische vernieuwingen in de $16 \mathrm{de}$ en 17 de eeuw

H J Genthe, Kleine Geschichte der neutestamentluchen Wissenschaft, Gottingen 1977

Populair Tot in de 19de eeuw lacuneus Voor de jongste tyd sterk op Oost Duitsland georienteerd

$\mathrm{O}$ Fatıo en $\mathrm{P}$ Fraenkel ed, Historre de l'exegese au XVIe siecle Textes du colloque international tenu à Genève en 1976 (Etudes de philologie et d'hıstoıre 34), Genève 1978

Bundel goede artıkelen, meest over indıvıduele exegeten vóór 1575 Van bijzonder belang is Fatıo's studie over G Hyperıus, wiens methodıek van de exegese (1556) mogelıjk meer invloed heeft gehad dan bekend is

II Geschiedenis van de bestuderng van het Grieks als geschreven in de tot Nieuzve Testament verenigde geschriften

R Simon, Historre critique du texte du Nouveau Testament, Rotterdam 1689 Bevat in hoofdstukken XXVI tot XXVIII een discussie over de 'stıle des Evangelıstes et des Apôtres', over 'la langue Hellenıstıque' en het desbetreffende geschil en een nadere beschouwing van Salmasius' standpunt terzake, dat wordt afgewezen

G B Winer, Grammatık des neutestamentlichen Sprachidıoms , Leipzig 1822, $1867^{7}$, bewerkt door P W Schmiedel, 2 dln, Gottıngen 1894/98

Biedt in een 'Erster Abschnitt' veel goede informatie over vroegere beoor delıngen van de aard van het nieuwtestamentısch Grieks

J Ros, De studie van het Bijbelgreeksch van Hugo Grotıus tot Adolf Deissmann, Nymegen/Utrecht 1940

Een nuttig historisch overzicht, maar soms teleurstellend kort en met merkwaardige lacunes ook in de biblıografie (hier ontbreken b v Schoockıus' Exercitatio prima en Salmasius' De modo usurarum en Funus, evenals S1mons Historre dutexte, zie hierboven Ros is te vooringenomen tegen de puristische traditıe ook in haar gematigde verschijnıngsvorm

J Irmscher, 'Der Stre1t um das Bibelgriechisch', Acta antıqua academıae scientiarum Hungaricae 7 (1959), pp 127 - 134

Beknopt maar instructief overzicht van de strıd tussen puristen en hebraisten vooral in Duitsland, zonder enige noot of biblografische verwijzing Ten onrechte heet het hier Heinsius 'nahm seinen Ausgang von Pfochen' ( $p$ 131), ten onrechte ook, dat Joh Vorstius in de Nederlanden zou hebben gewerkt ( $p$ 132), in plaats van in Berlın

Aem Springhettı, Introductio historica-grammatıca in graecıtatem Novı Testamentr, Romae 1966

Caput II, 'Sententiae de natura graecitatis Novı T', registreert, nogal erg 
Verzoeke betaling binnen 14 dagen, tenzij anders overeengekomen Postgiro 5567671

Amro Bank rek.nr 44.97.33.580
Payment within 2 months of invoice date on behalf of Kok Int. Books into one of the following accounts: Amro Bank N.V. Amsterdam 44.97.33.580 Postal cheque account 5567671

Postscheckkonto 5567671 Or by cheque or international money order 
schematisch geordend en zonder veel discussie, een groot aantal titels van $16 \mathrm{de}-, 17 \mathrm{de}-$ en $18 \mathrm{de}-\mathrm{eeuwse}$ werken over het nieuwtestamentisch Grieks.

G. Friedrich, 'Zur Vorgeschichte des Theologischen Wörterbuchs zum Neuen Testament', in: G. Kittel/G. Friedrich, Theologisches Wörterbuch zum Neuen Testament, X, Stuttgart enz. 1978, pp. 1 - 52.

Niet slechts over nieuwtestamentische woordenboeken, als die van Pasor, ook over o.m. Pfochen, puristen en hebraïsten, en Heinsius. Meer breed dan diep, maar als inleiding goed.

\section{Geschiedenis van de nieuwtestamentische tekst en tekstkritiek}

a. Geschiedenis van de edities

J. J. Wetstenius ed., Novum Testamentum Graecum, 2 dln, Amstelaedami 1751/2, I, 'Prolegomena', pp. 116 - 181.

Met ampele bespreking van de onderscheiden edities.

A. G. Masch, Bibliotheca Sacra post cl. cl. vv. Jacobi le Long et C. F. Boerneri iteratas curas ordine disposita, emendata, suppleta, continuata, Pars I, 'De Editionibus Textus Originalis', Halae 1778.

Biedt zeer veel; hoewel verouderd, nog steeds van nut.

S. P. Tregelles, An Account of the Printed Text of the Greek New Testament, London 1854.

Uitstekend, minutieus relaas over alle belangrijke edities van de Complutensische polyglot tot Tischendorf.

Ed. Reuss, Bibliotheca Novi Testamenti Graeci, Brunsvigae 1872.

Vrijwel complete lijst van alle edities van het Griekse Nieuwe Testament, genealogisch geordend en uit teksthistorisch oogpunt beschreven.

H. C. Hoskier, A Full Account and Collation of the Greek Cursive Codex Evangelium 604, London 1890.

Bevat uiterst waardevolle appendices met collaties van de edities Stephanus 1550 tegen Elzevier 1624 en twintig andere 16de- en 17de-eeuwse edities, alsmede een volledige, minutieuze collatie van Elzevier 1624 tegen Elzevier 1633.

T. H. Darlow en H. F. Moule, Historical Catalogue of the Printed Editions of Holy Scripture, Vol. II, 'Polyglots and Languages other than English', London 1903, reprint New York 1963.

Van belang om de secties Polyglots, Greek, maar ook voor de oude vertalingen. Vermeldt en beschrijft, niet geheel zonder kleine vergissingen, de exemplaren van gedrukte uitgaven aanwezig in de omvangrijke collectie van de British and Foreign Bible Society.

C. H. Turner, The Early Printed Editions of the Greek Testament, Oxford 1924. Een kort (28 pp.) doch boeiend relaas van een bibliofiel, bijna uitsluitend over de 16 de eeuw. 


\section{b. Geschiedenis van de tekstkritiek}

N.B. Hier volgt slechts een selectie uit de bestaande literatuur. In bijna alle genoemde werken komen ook de oude vertalingen en hun wetenschappelijke bewerking ter sprake.

$$
\text { (Amsirsin-lecpreg 1710, }
$$

J. Millius en L. Kusterus, Novum Testamentum Graecum, $\backslash$ Roterodami 1710, ook met andere titelbladen uitgebracht te Lipstae 17210 Lipsiae 1723 en Amstelodami 1746.

De briljante Prolegomena handelen van pp. 28 tot 153 tot in de fijnste details 'De statu Sacri Textus Novi Testamenti per omnia Ecclesiae secula'. Klassiek.

R. Simon, Histoire critique du texte du Nouveau Testament, Rotterdam 1689. Klassiek.

F. H. A. Scrivener, A Plain Introduction to the Criticism of the New Testament, Cambridge $1883^{3}$ (een vierde editie werd verzorgd door Edw. Miller, London 1894).

Chapter V. 'On the Early Printed, and Later Critical Editions of the Greek New 'Testament', pp. 416 - 489.

Ed. Reuss, Die Geschichte der Heiligen Schriften Neuen Testaments, Braunschweig $1887^{6}$, vooral 'Drittes Buch. Geschichte des Textes'. Bewerking en verbetering van zijn bovengenoemde Bibliotheca. Blijft van belang om de talrijke verwijzingen naar 18de- en 19de-eeuwse literatuur.

C. R. Gregory, Textkritik des Neuen Testamentes, Leipzig 1900/1909.

'Von 1500 bis 1902', pp. 921 - 993. Op p. 937 blijkt Gregory in de mening te verkeren, dat Scaliger na Mills (gest. 1707) geleefd heeft. De passage is een mislukte vertaling (door iemand anders dan Gregory?) van een corresponderende passus in Gregory's 'Prolegomena' tot C. Tischendorf, Novum Testamentum Graece, editio octava critica maior, III, 1, Lipsiae 1884, p. 216.

Eb. Nestle, Einführung in das Griechische Neue Testament, Göttingen $1909{ }^{3}$. I. 'Die Geschichte des gedruckten Textes seit 1514', pp. 1 - 32.

Eb. Nestle en E. von Dobschütz, Einführung in das Griechische Neue Testament. Vierte Auflage, völlig umgearbeit, Göttingen 1923. I. B. 'Die Zeit der Drucke', pp. 60 - 76.

F. C. Kenyon, Handbook to the Textual Criticism of the New Testament, London $1901,1926^{2}$.

Ch. VII. 'Textual Criticism in the Past'.

B. M. Metzger, The Text of the New Testament. Its Transmission, Corruption, and Restoration, Oxford 1964, 1968 2.

'Part Two: The History of New Testament Textual Criticism as Reflected in Printed Editions of the Greek Testament', pp. 95 - 146. 
c Geschuedens van de tekstkritzek in het bijzonder van de oude vertalingen

$\mathrm{R}$ Simon, Historre critrque des versions du Nouveau Testament, Rotterdam 1690

Klassiek

A Voobus, Early Versions of the New Testament, Stockholm 1954

B M Metzger, The Early Versions of the New Testament Their Ongin, Transmission and Limitations, Oxford 1977

Zeer veel verdere literatuur vindt men vermeld bij Metzger Daar aan de vulgata in Noord-Nederland in de 16de en 17de eeuw niet veel kritische arbeid is verricht (in tegenstelling tot in het Zuiden), laat ik literatuur over de geschiedenis der kritıek aan de vulgata hier achterwege

IV Achtergrond en context van de nieuwtestamentische studien in Noord Nederland in de 17 de eeuw

H H Kuyper, De opleiding tot den Dienst des Woords by de Gereformeerden, 's-Gravenhage 1891

Goed verslag van de geschiedenıs der gereformeerde theologische opleidingen, met speciale aandacht voor hun positie ten opzichte van de overheid De schrijver heeft een scherp oog voor de plaats en functie van de exegese binnen de oude theologische opleidingen en haar verhouding tot de leerstellige theologie

Chr Sepp, Het godgeleerd onderwins in Nederland gedurende de 16 e en 170 eeuw, 2 dln, Leiden 1873/74

De beschrıjvingen van wetenschappelıjke werken blıjven nogal erg uitwendıg en oppervlakkıg, maar overıgens een knappe reportage van de rıjk geschakeerde theologische wereld waarm en waarnaast de boven beschreven geschiedenıs der exegese zich afspeelde

L Muller, Geschichte der klassischen Philologie in den Niederlanden, Leipzig 1869

Ondegelık en rommelıg, maar noolt door een werk over hetzelfde onderwerp vervangen

W M C Juynbol, Zeventiende-eeuwsche beoefenaars van het Arabisch in Neder land, Utrecht 1931

Een goed overzicht

J Brugman en F Schroder, Arabıc Studies in the Netherlands (Publications of the Netherlands Institute of Archaeology and Arabic Studies in Catro 3), Leiden 1979 


\section{Corollarium}

Bij wijze van uitzondering op de beperkingen gesteld in de inleiding tot deze bibliografie mogen twee verdere publicaties worden vermeld.

W. Bousset, 'Die Geschichte der Auslegung der Apokalypse', = hoofdstuk IV van de 'Einleitung' tot zijn Die Offenbarung Johannis, Göttingen $1906^{6}$, reprint 1966, pp. $49-119$.

Buitengewoon knap, ondanks beknoptheid rijk aan details, ook over Nederlandse 16de- en 17de-eeuwse commentatoren als Junius, Drusius, De Dieu en A Marck. Zeer raak in beoordelingen. Een van de beste uitleggingsgeschiedenissen van een nieuwtestamentisch boek.

H. G. Klemm, Das Gleichnis vom Barmherzigen Samariter. Grundzüge der Auslegung im 16./17. Jahrhundert (Beiträge zur Wissenschaft vom Alten und Neuen Testament. Sechste Folge, Heft 3. Der ganzen Sammlung Heft 103), Stuttgart enz. 1973.

Een aardig voorbeeld van een exegese-geschiedenis van één pericoop.

Wat in de reeks 'Beiträge zur Geschichte der neutestamentlichen Exegese', Tübingen 1955, vanaf dl 2 (1959) onder de serietitel 'Beiträge zur Geschichte der biblischen Exegese' verschenen is, staat met het door ons behandelde doorgaans slechts in verwijderd verband. 


\section{Verantwoording van de illustraties}

1. Groepsportret van internationaal gezelschap van nieuwtestamentici, in fictieve vergadering bijeen. Toen de oudste afgebeelde geleerde overleed, nl. Camerarius ( $\dagger$ 1574), moesten vijf andere nog geboren worden, nl. Heinsius (1580), Grotius (1583), Salmasius (1588), De Dieu (1590), Spanheim (1600). De geportretteerden zijn geselecteerd naar hun (door Walaeus geschatte) betekenis voor de filologische en historische opheldering van het Nieuwe Testament.

Kopergravure door Jacob van Meurs, ca. 1653, naar bewaard gebleven potloodtekening mogelijk van dezelfde. Detail van het gegraveerde titelblad van Balduinus Walaeus, Novi Testamenti libri Historici..., Leiden 1653.

Particuliere collectie.

2. Portret van Joseph Scaliger. Het zesregelig lofdicht is van Daniël Heinsius. Het hier gereproduceerde exemplaar voorzag Scaliger in zijn laatste levensjaar eigenhandig van een ondertekende opdracht aan de Leidse rector magnificus Cornelius Gro(o)tius (oom van Hugo, rector 1608/9)

Kopergravure door Bartholomeus Dolendo, 1607.

Leiden, Academisch Historisch Museum.

3. Stephanus Curcellaeus, ed., Novum Testamentum. Editio nova, denuo recusa: in qua diligentius quam unquam antea variantes lectiones ... et parallela scripturae loca annotata sunt, Amstelodami, Blaeu, 1685, pp. 502 - 3. Derde druk van voor het eerst in 1658 verschenen editie.

Leiden, Bibliotheek der Rijksuniversiteit.

4. Titelblad van Georgius Pasor, Grammatica Graeca Sacra Novi Testamenti Domini Nostri Jesu Christi ... In gratiam S. Literarum et Linguae Graecae Studiosorum nunc primum edita, Groningae Frisiorum (Cöllenius) 1655. Eerste grammatica van het Grieks van het Nieuwe Testament, posthuum uitgegeven door Pasors zoon Matthias. Het boek is zeldzaam.

Particuliere collectie. 
5. Specimen van de annotatie van het Nieuwe Testament door Johannes Drusius, gekozen uit I. Drusius, Annotationum in totum Jesu Christi Testamentum siue Praeteritorum libri decem, Franekerae (Rakaeus), 1612, pp.76-7.

Leiden, Bibliotheek der Rijksuniversiteit.

6. Portret van Louis de Dieu.

Olieverfschilderij door Pieter du Bordieu, ca. 1640.

Hannover, Niedersächsische Landesgalerie.

7. Portret van Daniël Heinsius.

Olieverfschilderij. Anonieme copie naar het in de collectie Barton te Londen bewaarde schilderij door Jacob Fransz. van der Merck uit 1645.

Amsterdam, collectie van de Universiteit van Amsterdam.

8. Specimen uit de synopsis der vier evangeliën in het Grieks van Joannes Clericus, Harmonia Evangelica, Amstelodami (Huguetani) 1699 (heruitgave met gewijzigd titelblad 1700), p. 186.

Leiden, Bibliotheek der Rijksuniversiteit.

9. Portret van Jo(h)annes Clericus (Jean Le Clerc).

Anoniem olieverfschilderij, misschien verwant met een prent door Bernard Picart uit 1710.

Leiden, Bibliotheek der Rijksuniversiteit. 
Verwezen wordt naar de bladzijden

\begin{tabular}{|c|c|}
\hline Mt. 156 & Joh. 1:5 32 \\
\hline Mt. 3:17 54 & Joh. $7: 53-8: 11 \quad 51$ \\
\hline Mt. $6: 34 \quad 44$ & Joh. $18: 3159$ \\
\hline Mt. $9: 17 \quad 45$ & Joh. $20: 31 \quad 15$ \\
\hline Mt. $12: 10 \quad 46$ & Hand. $1: 18 \quad 58,61$ \\
\hline Mt. 12:18 54 & Hand. 6:1 32 \\
\hline Mt. 17:5 54 & Hand. 13: $20 \quad 59$ \\
\hline Mt. $22: 39 \quad 41,44$ & Hand. 16:12 22, 25, 55 \\
\hline Mt. 23: $24 \quad 45$ & Hand. 19:31 57 \\
\hline Mt. 26:75 53 & Rom. 3:29 17 \\
\hline Mt. 27:5 58, 61 & Rom. 14:5 51 \\
\hline Mt. 27:35 50 & Rom. $15: 4 \quad 15$ \\
\hline Mc. $1: 1154$ & I Cor. $2: 13 \quad 15$ \\
\hline Mc. $6 \quad 61$ & I Cor. $15: 2960$ \\
\hline Mc. 7:3 60 & II Cor. $10: 10-11 \quad 15$ \\
\hline Mc. 9:7 54 & Gal. 11 \\
\hline Mc. 12: 654 & Eph. 1:3-7 17 \\
\hline Mc. $14: 41 \quad 47,49$ & Eph. $2: 1-10 \quad 17$ \\
\hline Mc. 14:72 53 & Philip. 66 \\
\hline Mc. 16 slot $42-43$ & Philip. 1:13 59 \\
\hline Lc. $2: 1-4 \quad 58$ & Philip. 2:30 22 \\
\hline Lc. $2: 7,12,16 \quad 60$ & I, II Thess. 74 \\
\hline Lc. $2: 49 \quad 49$ & Tit. 26 \\
\hline Lc. 356 & Hebr. 47,60 \\
\hline Lc. $6: 7 \quad 46$ & Hebr. 6:17 14 \\
\hline Lc. $6: 41 \quad 45$ & Jac. 60 \\
\hline Lc. $12: 10 \quad 51$ & II Petr. 60,74 \\
\hline Lc. $12: 49 \quad 51$ & I, II, III Joh. 60 \\
\hline Lc. $15: 1832$ & Jud. $\quad 60$ \\
\hline Lc. $20: 13 \quad 54$ & Openb. 26,60 \\
\hline
\end{tabular}


1. Auteurs tot ca. 1700

Alberti, J. 38

Alting, J. 14

Amama, S. 29

Andreae, T. 30

Antonides, J. 26

Arminius, J. 14

Beza, Th. 10, 21, 22, 23, 35, 49,79

Bos, L. 38, 67

Boxhorn, M. Z. $69-70$

Braun, J. 47

Calvijn, J. 12, 13

Camerarius, J. 10

Castellio, S. 35

Clenardus, N. 30

Clerc, J. le, zie Clericus

Clericus, J. 24-26, 55, 60-62, $64-66,67$

Coccejus, J. 13, 36

Coddaeus, W. 21

Comenius, J. A. 30

Coolhaes, C. 11

Cotelier, J. B. 66

Crenius, Th. 70-71

Croy, J. de 30

Curcellaeus, Steph. 24, 25, 27, 67

Dieu, L. de 10, 26, 47-51, $53-54,67,82-83,91$

Drusius, J. 32, 35, 41-46, $53-54,55,67,91$

Elzeviers 22

Empereur, C. 1' 36, 82-83

Episcopius, S. 55

Erasmus, D. 22, 26, 35, 39, 47, 51,73
Erpenius, Th. 26, 27, 67, $73-74$

Estienne jr., H. 22

Estienne, R. 22, 24

Fell, J. 24

Fugueray, G. 11, 13

Fuller, N. 49

Gaillard, J. 57

Gataker, T. 36

Gomarus, F. 10, 13, 39, 55, 56

Grousset, J. 30

Gronovius, Jac. 30, 58

Grotius, H. 7, 10, 14, 54-55, $58,60,67,72-76,83$

Halloix, P. 63

Hammond, H. 55

Heinsius, D. 10, 22-23, 32-35, $36,39,51-54,55,63,67$, $69-71$

Heucherius, S. 82-83

Hoelzlin, J. 22

Honert, T. H. van den 37

Huber, U. 59

Huygens, C. 69

Junius sr, F. 13, 23, 91

Kusterus, L. 89

Lasco, J. a 13

Leusden, J. 27, 30, 37, 55, 67

Lightfoot, J. 46

Limborch, $\mathrm{Ph}$. van 14

Lombardus, P. 11, 12

Maets, C. de 17

Marck, J. a 41, 59-60, 91

Mercerus, J. 50, 79

Mills, J. 24, 26, 89

Moyne, E. le 63-64

Münster, S. 50 
Pasor, G. $28-31,35,36,41$, 67, 82

Pearson, J. 41, 55

Perizonius, J. 58, 59

Pfochen, S. 35-36, 37, 82

Pococke, Ed. 26

Polus (Poole), M. 55, 59, 85

Polyander, J. 15, 16-17, 82-83

Posselius, J. 30, 31

Raphelengius, F. 22, 26

Rhenferd, J. 37

Rivetus, A. 15, 23

Rossal, M. 30

Salmasius, C. 10, 32-35, 36, $53,55,60,61,63-64,67$, $69-71,83$

Saravia, A. 13

Sarrau, C. 70

Scaliger, J. 7, 10, 20-24, 26, $32-33,45,55,56,60,61,63$, $67,68,78-81$

Schaaf, C. 27

Schoockius, M. 33, 37, 57, 67, $70-71$

Schotanus, C. 30

Schottus, A. 63-64

Sibranda, J. 59

Simon, R. $64,85,87,89,90$

Solanus, M. 37

Spanheim jr., F. 57, 67

Spanheim sr., F. 10

Surenhusius, G. 57

Teunisz, zie Antonides

Thomas Aquinas 11

Thysius sr, Ant. 15, 21, 24, 83

Trelcatius sr, L. 13

Triglandus, J. 83

Trommius, A. 30

Ussher, J. 50, 63-64

Valla, L. 39,47

Voetius, G. 69-71

Vossius, G. J. 30, 56, 58, 79

Vossius, I. 63, 64

Walaeus, A. 15,83

Walaeus, B. 54, 61

Widmar, A. 17

Witsius, H. 41, 59-60
Zwingli, U. 12

2. Auteurs vanaf ca. 1700

Baarda, T. 22

Baljon, J. M. S. 25

Bauer, W. 25, 53

Bengel, J. A. 24

Billerbeck, P. 46

Bots, J. A. H. 70

Bousset, W. 91

Bowyer, W. 25

Brugman, J. 90

Bultmann, R. 45

Burmannus, P. 30

Clark, A. C. 25

Darlow, T. H. 88

Deissmann, A. 30

Delling, G. 30,31

Dibon, P. 17

Dobschütz, E. von 89

Duker, A. C. 69

Eijl, E. J. M. van 11

Ekkart, R. E. O. 41

Farrar, F. W. 85

Fatio, O. 87

Fraenkel, P. 13, 87

Friedrich, G. $31,35,88$

Furnish, V. P. 18, 86

Genderen, J. van 60

Genthe, H. J. 87

Gerretzen, J. G. 30

Goens, R. M. van 30

Golden, S. A. 24

Grant, R. M. 17, 86

Gregory, C. R. 89

Haenchen, E. 25

Hall, B. 86

Hemsterhuis, T. 30

Hilgenfeld, A. 85

Horst, D. J. H. ter 71

Horst, P. W. van der 63

Hoskier, H. C. 88

Howard, W. F. 7, 86

Irmscher, J. 87

Jones, D. R. 86

Juynbol, W. M. C. 90

Kenyon, F. C. 89 
Klemm, H. G. 91

Kümmel, W. G. 7, 54, 66, 86

Kuyper, H. H. 12, 13, 90

Lebram, J. C. H. 21, 41

Lamping, A. J. 17, 57, 82

Leipoldt, J. 61

Luzac, J. 30

Masch, A. G. 88

Meijer, T.J. 58-59

Metzger, B. M. 27, 51, 89, 90

Meyer, G. W. 85

Moule, H. F. 88

Müller, L. 90

Nestle, Eb. 89

Nestle, Erwin 25

Nineham, D. E. 86

Posthumus Meyjes, G. H. M. 57

Preuschen, E. 25

Reuss, E. 86, 88, 89

Ros, J. $30,35,36,37,87$
Rosenberg, A. W. 73

Ruhnkenius, D. 30

Schmiedel, P. W. 87

Scholder, K. 18, 86

Schröder, F. 90

Scrivener, F. H. A. 89

Sellin, P. 69-71

Sepp, C. 90

Springhetti, Aem. 87

Tischendorf, C. 27

Tregelles, S. P. 88

Turner, C. H. 25, 54, 88

Unnik, W. C. van 72-76

Valckenaer, L. C. 30

Vööbus, A. 90

Wettstein, J. J. 21, 24, 88

Witkam, H. J. 11

Winer, G. B. 87

Wood, J. D. 86

Wyttenbach, D. 30 
Amsterdam 13, 24-25, 54, $55-57,61,66,67,72$

annotationes $39-55,56,67$, 72-76

Antwerpse Polyglot 22, 27, 50

Apostolische Vaders 63-66

Arabisch 26, 47, 49, 50

Aristotelisme 14-16

Armeens 27

Barnabas 63-64, 66

Bazel 12

Cambridge 46

Canones Apostolorum 63

Clemens Romanus 66

Codex Alexandrinus 24, 25

commentaren 39-55, 72

Complutensische Polyglot 22, 24

conjecturen 22, 23, 25

Constitutiones Apostolicae 63, 66

Critici Sacri 41, 45, 55, 78

Deventer 70

Dionysius Areopagita 63

disputaties $11,15-16,60,83$

Dordrecht, Synode van 17, 27, 74

Ethiopisch 47, 50

Franeker 13, 29-32, 35-38, $41-42,45,58-59,60,67$

Genève $10,12,33,77$

Glossa Ordinaria 12

Gotisch 27

Grieks van het N.T. 15, 28-39, $82-83$

Groningen $10,13,14,17,28$, $30,31,33,37,47,56,57,59$, $60,67,70-71,80$

Harderwijk 13, 24, 67 harmonisatie $21,56-62,67$

hebraïsten $35-37,82-83$

Hebreeuws 11, 12, 29, 33, $40-41,50,79,82-83$

Heidelberg 12

Hellenisten, -stisch 15, 32-37, $69-71,83$

Herborn 30

Ignatius Antiochenus 64,66

Josephus 60,61

kerkvadercitaten 21, 23

kerkvaders 40, 51-54

Lausanne 12, 13

lectio difficilior 26

Leiden 10-13, 14-16, 21-24, $26-27,30,32-35,37,41,47$, $57-59,64,67,82-83$

Leipzig 10

Leuven 11

loci communes 12-13

Londen 13, 55

Londense Polyglot 24, 27

Nestle $^{26} 25$

observationes $37-38$

Oxford 26, 41, 63, 64

Parijs $10,54,66,72$

Pesjitta 27

Polycarpus 63-64, 66

Ps.-Clementina 66

Ps.-Phocylides 63

puristen, -sme $35,37,38,82$

rabbinica $14,36,39-47,53,54$, $60,68,73$

Remonstrant(s) 10,13,14,18, 24, 67

Rostock 30

Scaligerana 80-81 
scholastiek 14, 15, 51

Sententiën 11

socinianen 16,17

synopse 61,62

Synopsis criticorum 55, 59, 85

Synopsis purioris theologiae 14-16, 83

Syrisch 26, 27, 47, 49, 50, 51

Textus receptus 22, 24, 34, 67

T.G.N.T. 25

trilinguis eruditio 18,29
Tübingen 10,12

Utrecht $13,17,27,30,33,37$, $55,59,67,69-71$

vertalingen, oude $26-27,40$, $47,49-50,67,90$

vulgata 47,90

Waals College $18,26,57,82-83$

Weimar 79

Wittenberg 12,59

Zürich 12 
129 SALMASIUS, C. Funus linguae Hellenisticae, sive confutatio exercitationis de Hellenıstıs et lingua Hellenistica. Leiden, ex officına J. Marre, 1643. Small-8vo. 390 p., errata leaf. [a few leaves stanned or with library stamp; old vellum copy, upper part of front-cover sl damaged]

Salmasius' last work on the nature of the Greek language of the New Testament before his dispute with Heinsius on the subject was formally settled on the initiative of the Curators of Leiden University Both Leiden professors agreed on the particular character of the New Testament language, but where Heinsius held it for a dialect of Hellenistic Jews who did not speak Hebrew or Aramaic, Salmasius argued that semiticisms were a result of translating Hebrew or Aramaic into Greek or an effect of the bilinguality of some Jews See Willems 558

The controversy did not remain confined to the Leiden world of learning as $M$

CATALOGUE N ${ }^{\circ} 583-$ E J BRILL, LEIDEN

Schoockius published an anonymous work to defend Heinsius' views and J de Croy chose the side of Salmasius See HJ de Jonge, De bestudenng van het Nieuwe Testament aan de Noordnederlandse universiteiten en het Remonstrants Seminane van 1575-1700, Amsterdam 1980, pp 32-7.

An appendix, Ossilegium linguae Hellenisticae, covers the last 109 pages 
für einen Fehlweg zu halten und dafür auch noch jene Tradition von Humanismus und Aufklärung verantwortlich zu machen. Man kann und muß, gerade als Theologe, gegen jene Tradition mancherlei auf dem Herzen haben; aber, daß sie auf vielen Gebieten und so auch dem der biblischen Exegese ihrerseits gegen zahllose "Voreingenommenheiten " und „Beschränktheiten" erfolgreich gekämpft und allererst ein „unbefangenes Urteil" ermöglicht hat, ist über jeden Zweifel erhaben. Darum dürften ihr gegenuber bei aller Distanz auch Bewunderung und Dankbarkeit am Platze sein.

Übrigens, was ist ein "Philosemitist" (S. 499)?

Göttingen

Rudolf Smend

De Jonge, H. J. De bestudering van het N.T. aan de Noord-nederlandse universiteiten en het Remonstrants Seminarium van 1575 tot 1700 . Amsterdam 1980. 93 S. kart.

Dr. H. J. de Jonge hat seine Abhandlung fur die Konigliche Niederlandische Akademie der Wissenschaften der Geschichte der Exegese im 16. und 17. Jahrhundert in den nördlichen Niederlanden gewidmet. Er beschränkt sich dabei nur auf Forscher, die in einer Universität oder am Remonstrantenseminar in Amsterdam gearbeitet haben. Besonders dieses Seminar war von Bedeutung für die Bibelforschung, weil Gelehrte, wie Episcopius, Curcellaeus und Clericus hier ihre wissenschaftliche Arbeit leisteten. Auch Wettstein arbeitete hier im 18. Jahrhundert, aber dieses Zeitalter wird in dieser Abhandlung außer Betracht gelassen.

Die Beschränkung auf die Forscher, die nur an der Universität ihre Arbeit leisteten, bedeutet aber, daß der Schriftsteller Hugo Grotius nicht mit seiner Arbeit einbezogen wurde, weil dieser nie an einer Universitat unterrichtet hat. Dr. de Jonge äußert sein Bedauern darüber auf Seite 54 und 55 seines Buches, wahrend er in einer Beilage wieder auf Grotius zurückkommt, den er für den wichtigsten Exegeten seiner Zeit hält. Hoffentlich wird Dr. de Jonge uns später noch eine Abhandlung über diesen genialen Menschen schreiben.

Diese kleine Schrift beschäftigt sich mit Autoren, die in der Theologiegeschichte wenig bekannt sind und sie muß deshalb zur Einzelforschung gerechnet werden. Aber das bedeutet nicht, daß die hier beschriebenen Forscher weniger von Bedeutung sind für die Entwicklung der Bibelınterpretation. Besonders Scaliger, Heinsius, Curcellaeus und Clericus haben auf diesem Gebiet Beträchtliches geleistet.

Dr. de Jonge beschreibt deutlich die Entwicklung von dogmatischen zur philologischen und historischen Exegese, wie sie schließlich der modernen Wissenschaft vorgreift. Am Anfang steht Erasmus, Scaliger folgt seiner Spur, Grotius war sein Bewunderer und Nachfolger. Die Schrift von Dr. de Jonge ist klar und gut geschrieben, wissenschaftlich ausgezeichnet dokumentiert und ein sehr willkommener Beitrag zur Geschichte der neutestamentlichen Exegese.

Gorssel

Gerrat Jan Hoenderdaal

Stanislaus Lubieniecki: Compendium Veritatis Primaevae, herausgegeben, eingeleitet und erklärt von K. E. Jordt Jørgensen. 2 Bände, Akademisk Forlag, Kobenhavn, 1982; 222, $494 \mathrm{~S}$.

Stanislaw Lubieniecki (1623-1675) gehörte zu den prominentesten Anführern des polnischen Sozinianismus im 17. Jahrhundert. Er entstammte einer aristokratischen Familie, hatte eine vielseitige Erziehung genossen, die u.a. Studienreisen nach den Niederlanden und nach Frankreich in sich schloß, und war 1652 Prediger in der Kirche der polnischen Brüder geworden. Der erste nordische Krieg zwang ihn zur Flucht und veranlaßte ihn, sich beim schwedischen König für das Los seiner Glaubensbrüder einzusetzen. Da der Friedensvertrag von Oliva (1660) die erwartete Wiederherstellung der Glaubensfreiheit fur die Sozinianer in Polen nicht verwirklichte, konnte auch Lubieniecki selbst nicht mehr in seine Heimat zurückkehren. Nach kurzen Aufenthalten in Dänemark und Pommern ließ er sich 1662 in Hamburg und 1668 in Altona nieder. Seine 

warden. In 1562 werd hij secretajaren laten benoemde Philips II Douai, maar ook daar bedankte hij irden van zijn tijd. Hij heeft zeer rogische onderwerpen; hij verzorgcen etc." ". NNBW.V, 498 .

An in $y A-j$

et semis in quibus non nodo

r.anequerae J.Horrei 1699 , (88) $498 \mathrm{p}$. leer, $8^{\circ}$

"In zijn Scriptoribus beschrijft Petri de levens van 165 schrijvers en geeft hij de titels van hun werken. Wat het laatste gedeelte betreft, is het zeer belangrijk." H.Brugmans in NNBW, V, 498 .

25 Prideau,H. Alt-und Neues Testament in eine Connexion mit der Juden und benachbarten Völcker Historie gebracht, vom Vervall der Reiche Israel und Juda an, biss auf Christi Himmelfahrt. Nach der Achtten Englischen Auflage, ins hoch-Teutsche übersetzet....Hinzugefügte älteste Geschichte der Welt...und Profan-scribenten vermehrt... und allerhand Kupffern.

Dresden J.M. Lobecken 1726,2 vol. in I. $(22)+96+56+724(32)+(18)$

$808(130) \mathrm{p}$. Leather, $4^{\circ}$

Nicely izlustrated edition of this esteemed account of the history of the Jewish people in the last centuries before the Christian era.

"... contains a large mass of erudition-and accurate information on every topic of Jewish history and antiquities. It is indispensable to the biblical and interesting to the general scholar."

New Schaff-Herzog, IX, 246; Oxford Dict.of Christian Church, p.1103; Dict. Nat.Biography XVI, 352 .

26 Psalmen Davids, met korte bemerkingen op den Historischen, Geestelijken en zedelijken zin. Benevens eenige Lof-zangen der H.Schriftuur, voornamelijk de gene die volgens de order van den Roomschen Brevier wekelijks in de Getyden der H.Kerke gelezen worden. Ghendt Fr.\& Dom.vander ween 1725, 2 vol. in I. (86) $326+(2)$ $414(10) \mathrm{p}$. velIum, $8^{\circ}$

27 Quistorp,J.N. Zhthmata in Epistolas I. et II. Johannis. Disputationibus VIII.

Wismariae \& Lipsiae J.Chr.Schmid 1708, 152p.new bound, 40 - 85,-

28 Raphelenchius, G. Annotationes in Sacram Scripturam, historicae in vetus, philologicae in Novum Testamentum, ex Xenophonte, Polybio, Arriano et Herodoto.

Iug.Bat. J.A.Langerak 1747, 2 vol. (164)680(2) + (2)802 +77(34)p. vellum, $4^{\circ}$

H.J.de Jonge, De bestudering van het NT. aan de Noordnederlandse universiteiten en Rem. Seminarie van 1575 tot 1700, 1980, 22-26.

29 Reineccio,M.Chr. Grammaticae Hebraeo-Chaldaicae...Harmanice \& Synoptice adornatae. Ed.novissima.

Viennae J.Th.Trattnern 1778, 152p. cloth, $8^{\circ}$

30 (...) De Regte Gronden van het Geloove, hope en Liefde;veroordeelt door de bul Unigentius, in haren Natuurlyken zin. Tot onder-regtinge van het Gemeen der Christenen en Verdediging der R.C. die om het niet aannemen van di Bul in Brandand en elders vervolgt worden. 's Gravenhage Bern.van Holzen 1731, (16)102 + (10)420p. leather, $8^{\circ}$ 
UD TON BOLLAND | antiquariaat $\mid$ veilingen $\mid$ taxaties

enkele malen tot hoogleraar werd benoemd, maar steeds bedankte. Afwisselend woonde hij in Leuven en zijn vaderstad Leeuwarden. In 1562 werd hij secretaris en bibliothecaris van Granvelle. Enkele jaren laten benoemde Philips II hem aan de nieuw gestichte Universiteit van Douai, maar ook daar bedankte hij voor. "Petri was een van de beroemdste geleerden van zijn tijd. Hij heeft zeer vele geschreven over philosophische en philologische ondemverpen; hij verzorgde klassieke tekstuitgaven, historische werken etc.". NNBW.V, 498. De Scriptoribus Frisiae Decades XVI, et semis in quibus non nodo peculiares Frisiae....

Franequerae J.Horrei 1699, (88)498p. Ieer, $8^{\circ}$

"In zijn Scriptoribus beschrijft Petri de levens van 165 schrijvers en geeft hij de titels van hun werken. Wat het laatste gedeelte betreft, is het zeer belangrijk." H.Brugmans in NNBW, V, 498 .

25 Prideau, H. Alt-und Neues Testament in eine Connexion mit der Juden und benachbarten völcker Historie gebracht, vom Vervall der Reiche Israel und Juda an, biss auf Christi Himmelfahrt. Nach der Achtten Englischen Auflage, ins hoch-Teutsche übersetzet....Hinzugefügte älteste Geschichte der Welt...und Profan-Scribenten vermehrt... und allerhand Kupffern.

Dresden J.M.Lobecken 1726,2 vol. in I. $(22)+96+56+724(32)+(18)$ $808(130) \mathrm{p}$. leather, $4^{\circ}$ - 475, Nicely illustrated edition of this esteemed account of the history of the Jewish people in the last centuries before the Christian era.

"....contains a large mass of erudition-and accurate information on every topic of Jewish history and antiquities. It is indispensable to the biblical and interesting to the general scholar."

New Schaff-Herzog, IX,246; Oxford Dict.of Christian Church, p.1103; Dict.Nat.Biography XVI, 352 .

26 Psalmen Davids, met korte bemerkingen op den Historischen, Geestelijken en Zedelijken Zin. Benevens eenige Lof-zangen der H.Schriftuur, voornamelijk de gene die volgens de Order van den Roomschen Brevier wekelijks in de Getyden der H.Kerke gelezen worden. Ghendt Fr.\& Dom.vander Ween 1725, 2 vol. in I. (86) $326+$ (2) $414(10) \mathrm{p}$. vellum, $8^{\circ}$

27 Quistorp, J.N. Zhthmata in Epistolas I. et II. Johannis. Disputationibus VIII.

Wismariae \& Lipsiae J.Chr.Schmid 1708, 152p.new bound, $4^{\circ}-85,-$

- 28 Raphelenchius, G. Annotationes in Sacram Scripturam, historicae in Vetus, philologicae in Novum Testamentum, ex Xenophonte, Polybio, Arriano et Herodoto.

Lug.Bat. J.A.Langerak 1747, 2 vol. (164)680(2) + (2) $802+77(34)$ p. vellum, $4^{\circ}$

H.J.de Jonge, De bestudering van het NT. aan de Noordnederlandse universiteiten en Rem. Seminarie van 1575 tot 1700, 1980, 22-26.

29 Reineccio,M.Chr. Grammaticae Hebraeo-Chaldaicae...Harmanice \& Synoptice adornatae. Ed.novissima.

Viennae J.Th.Trattnern 1778, 152p. cloth, $8^{\circ}$

30 (...) De Regte Gronden van het Geloove, hope en Liefde; veroordeelt door de bul Unigentius, in haren Natuurlyken zin. Tot onder-regtinge van het Gemeen der Christenen en Verdediging der R.C. die om het niet aannemen van di Bul in Brandand en elders vervolgt worden. 's Gravenhage Bern.van Holzen 1731, (16) $102+$ (10)420p. leather, $8^{\circ}$ 
It is suggested that the overall organisation of the Temple Scroll follows the Pentateuchal order The table on $\mathrm{p} 15$ which should support this suggestion, rather contradicts it It leaves out of the picture Genesis and Ex 1-24 and shows the following sequence Ex 25-40, Lev Num, Ex 25-40, Lev Num Deut The author further ascertains that the claim for authority is manifest in the use of the term "Torah" In col $2 \mathrm{e} g$ the expression Torat hammišpat is understood as designating the title of the whole book presenting it as an alternative to the canonised 'Torah' However, the status constructus in this expression hardly allows such an interpretation As for Zadok it is true that the issue of his identity has been treated only casually in previous scholarly publications (p 99) It is likely that Zadok in the Qumran texts (except in the quotation of Ez 44,15) refers to the Teacher of Righteousness (p 140) However it is not so sure that the term usually transliterated as Zadok was meant as a name The term is interchangeable with $s d q$ and $s d y k$ and may mean 'righteousness' or 'righteous' This is e g suggested by 1 Q S 9,14 which reads bny hsdwq Sons of Righteousness, and not bny $s d w q$ Sons of Zadok as in Wacholder p $264 \mathrm{n} 188$ The prophetic text of Ex 44,15 has played an important role in the community, not because it contained the name of Zadok, but because it was possible, by means of the midrashic canon of interpretation, to read the meaning 'Sons of Righteousness' into bny $h s d w q$ (see P Wernberg-Møller in $V T 3$, (1953, 314) Moreover, it should not be taken for granted that the title "Teacher of Righteousness" and equivalent titles always refer to one and the same person Wacholder strongly suggests that the term 'Wicked Priest' applies to a succession of persons We would have liked to see a similar suggestion applied to the title 'Teacher of Righteousness' (see $\mathbf{J}$ Starcky in BETL XLVI, Gembloux Leuven, 1978, p 249-256) The two topics of the 'Second Tordh', and of 'Zadok' are brought together in the assertion that 'Zadok' or the Teacher of Righteousness was not only the finder of the 'Second Torah' (CD 5,5) but also its author The latter part of the assertion is hinted at several times e g p 4,33 However it does not seem to be explicitly argued and backed by a solid argumentation The interesting chronology defended by Wacholder depends to a large extent on the literal interpretation of the data given in the CD 1,5-10 However, the 390 years mentioned there almost certanly refer to Ez 4,5 and seem to have a symbolic meaning It is doubtful whether they may also be taken literally

The book is completed with a bibliography and with several helpful indexes All future scholarly research on Qumran will have to consider this daring work seriously

H J DE JONGE De bestudering van het Nueuwe Testament aan de Noordnederlandse universitetten en het Remonstrants Seminarte van 1575 tot 1700 (Verhandelingen Kon Ned Academie van Wetenschappen, Afd Letterkunde, N R 106 ) Amsterdam-Oxford-New York, Noord-Hollandsche Uitgevers Maatschappı, $198018 \times 26$, $99 \mathrm{p}$

Nous avons eu deja l'occasion de presenter les etudes de $\mathrm{H} \mathbf{J}$ de Jonge sur l'edition des Elzevier et l'historre de l'exegese neotestamentarre aux Pays-Bas pendant le $17^{\mathrm{c}}$ siecle (cf ETL 56, 1980, 390-396, voir p 391, n 8, Evangelica, 934-940) Dans le volume commemoratif Leiden University in the Seventeenth 
Century (1975) il a écrit le chapitre sur The Study of the New Testament (p. 65109). Le présent travail traite la même période de 1575 à 1700 . La première date est celle de la fondation de l'université de Leiden, qui fut suivie par l'établissement d'autres universités et facultés de théologie: Franeker (1585), Groningen (1614), Utrecht (1636), Harderwijk (1648) et le Séminaire arminien à Amsterdam (1634). La période s'achève vers 1700 avec la publication des grands ouvrages de Clericus. Après un premier chapitre sur l'organisation des études à une université protestante, l'Auteur parle successivement de la critique textuelle, l'enseignement du grec, l'exégèse philologique, l'explication harmonistique et archéologique et l'étude des Pères Apostoliques (11-68). Des questions plus spéciales font l'objet de quatre appendices (69-83), suivis d'une bibliographie annotée sur l'histoire de l'exégèse (85-91) et plusieurs registres. L'Auteur a bien montré le rôle important qu'ont joué les professeurs des facultés des arts. Il dispose d'une connaissance de première main et son exposé est agréable à lire.

Une remarque cependant à propos du chapitre sur l'exégèse philologique, où il fait l'éloge de Drusius, De Dieu et Heinsius. Ses jugements sur l'originalité de leurs positions ont parfois besoin d'être nuancés. Ainsi, à propos de $\alpha \gamma \alpha \pi \eta \tau$ ró en Mc 1,11 et par. au sens de fils «unique» (C. H. Turner, 1926): «Na meer dan drie eeuwen wordt zo in zekere zin eer betuigd aan Heinsius' kennis van het Grieks en opmerkingsgave» (54). Mais bien avant Heinsius, Maldonat avait déjà écrit:

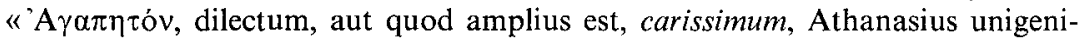
tum interpretatur. Hoc enim epitheto non apud Homerum solum, sed etiam in sacris litteris unigenitos filios solitos appellari». Autre exemple: Mc 14,72

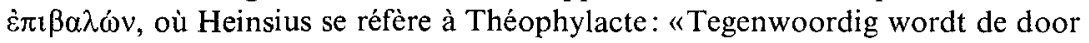
Heinsius bepleite interpretatie algemeen geprefereerd of zonder meer aanvaard [ $B-D, T W N T$, Bauer] ... Dat voor zover bekend Heinsius de eerste is geweest die dit belangrijke getuigenis [van Theophylactus] heeft geciteerd en gehonoreerd zal men noch daar, noch in enig ander naslagwerk of commentaar meer lezen» (53). Mais l'on peut lire la référence à Théophylacte entre autres chez notre Cornelius Jansenius (Gandavensis) (1571) et encore chez Lucas Brugensis (1606): «in quem sensum Interpretes Latinus et Syrus verterunt Coepit flere. Eadem autem alia interpretatio Theophylacti, magna vehementia coepit flere». Un troisième exemple est celui de L. de Dieu qui traduit à $\varepsilon_{\varepsilon} \chi \varepsilon t$ en Mc 14,41 par «peractum est», en accord avec la version syriaque (49). Ici encore Lucas Brugensis peut être cité. Il note la difficulté de la traduction courante: «Graece est $\dot{\alpha} \pi \dot{\chi} \chi \varepsilon 1$, quod verbum magnam movet difficultatem peritis Graece: non videtur significare sufficit». Il cite la version syriaque ( Advenit finis venitque hora») et il ne fait pas de doute qu'il explique $\dot{\alpha} \pi \dot{\chi} \chi \varepsilon 1$ dans ce sens: «Ea quae sunt de me finem habent» (cf. Lc 22,37).

F. NEIRYNCK

Kurt Aland (éd.). Vollständige Konkordanz zum griechischen Neuen

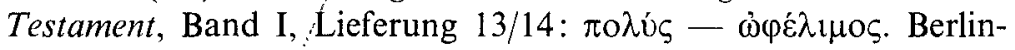
New York, Walter de Gruyter, 1983. $23 \times 31$, pp. 1153-1352. DM 236.

Commencée en 1975/la publication de la nouvelle Concordance s'achève avec ce fascicule double signé par son éditeur le 31 octobre 1982. Le tout se présente maintenant en deux parties: Teil 1, A- $\Lambda$ (p. 1-752) et Teil $2, M-\Omega$ (p. 753-1352), avec une introduction par K. Aland (Vorbemerkung, p. V-VII) et les «Indications 
zoewel alle nadruk gelegd wordt op een ex sstentièle mensopvatting in navolging van S. Kierkegaard, wordt jier her geloof benaderd als een uitstaan van de mens naar de Ander als uiteindelijk centrum van alle ingeving.

Aichel, Marc. Voses nowvelles pour la théologie, Paris, Ed. du Cerf, ISBN 2-204-01656-X,1980, 11 × 18 , $13 \mathrm{blz}$.

Aarc Michel, 'professeur à l'Université des sciences humaines de Strasbourg', probért in dit kleine werkje oor leken duidelijk te maken hoe de theologie door invlued van de menswetenschíppen in onze tijd nieuwe regen is gegaan $\mathrm{Hij}$ doet dit door enerzijds aan te tonen hoe de theologie is opgenomen in de iermeneutische evolutie van de menswetenschappen en anderzijds door hét eigen wetenschapskarakter van e theologie als geloofswetenschap te verduidelijken. Hij begint met de constatering dat theologie een chrift-gegeven is (un fait d'écriture) in de spanning van her-schtrifven van het geschrevene, van lezing en rer-lezing. Een inleiding tot de theologie heeft dan ook als eerste taak te leren lezen. De auteur doet dit aan e hand van twee teksten, van Augustinus en van Vat.II In,en tweede hoofdstuk wordt vervolgens, in een eer summier overzichit van de geschiedenis, gewezegr op de verschillende schrijf-modellen welke de heologie in de loop de eeuwen heeft ontwikkeld. Het derde hoofdstuk beschrijft ten slotte de korte lominantie van één model, het dogmatisch mode/, en hoe dit model het veld moet ruimen voor een meer iermeneutische aanpak dank zij de ontwikketing in de exegese, de historische wetenschappen en de nenswetenschappen Hiermee is voor de theologie een nieuwe ruimte geopend de theologie wordt een orm van hermeneutiek. De auteur laat eít zien 0 a. aan de hand van de progressieve ontwikkeling van erkelijke uitspraken over de autoritejt van schrift en traditie. Als één vorm van hermeneutick heeft de heologie toch een specifieke waarbeídsbenadering: niet die van het weten, maar die van de onthulling. Het roekje eindigt met een korte analyse van de huidige christologie als voorbceld niet alleen van het lermeneutisch theologiseren maar ook als exposite van de sleutelpositie van dit tractaat voor alle verder heologiseren.

Het gaat hier om een zeer beknopte studic. Voor de vakmensen bevat dit werk niet veel nieuws, maar voor tocenten die belast zijn met de taak studenten in de theologie te introduceren bevat dit boekje interessante ranwijzingen en zeer bruikbare voorbeelden.

W. G. Tillmans

onge, H. J. de. De bestudering van bet Nieuwe Testament aan de Noordnederlandse universitetten en bet Remonstrants Seminarse van 1575 tot 1700, (Verhandelingen der Konnklijke Nederlandse Akademie van Wetenschappen, Afd. Letterkunde, Nieuwe Reeks, deel 106), Amsterdam, North-Holland Publ. Comp., ISBN 0-4448-5501-7, 1980, 18 x 26, 99 blz., US\$ 22,-, f 45,-.

Kümmel heeft in zijn geschiedenis van de exegese van het NT slechts de laatste twee eeuwen, de opkomst en te bloei van de historisch-kritische methoden behandeld

De Jonge toont aan dat veel van de principes, die de latere bijbelcritici huldigden, reeds hun wortels hebben in de $16^{\mathrm{e}}$ en $17^{\mathrm{c}}$ eeuw. In zijn boek behandelt hij slechts het onderzoek naar het NT aan de wetenschappelijke nstituten in Noord Nederland; de beschrijuing is gebaseerd op een keuze uit het enorme bronnenmateriaal. Criterium is daarbij, wat achteraf als van duurzaam belang te karakteriseren is. Daarom veel aandacht voor de eerste sporen van tekstkritiek (II Tekstkritiek en oude vertalingen; VI Vroegchristelijk letterkunde). Het criterium 'tekstkritisch' weegt echter ook zwaar in 2 van de andere 4 capita (I Dogmatische en filologische interesse in het NT: V Harmonische en oudheidkundige verhandelingen over NT stof).

De eigenheid echter van opvattingen aangaande $17^{\mathrm{e}}$-eeuwse onderzoeksmethoden (m.n. die van de bijbel) blijven op de achtergrond. Als er ooit een groter onderzoek komt naar de geschiedenis van de NTische exegese, dan ontkomt men er niet aan juist ook de uitlegprincipes van de ontstaanstijd nader te bestuderen. Foucault (cfs. Les Mots et les Choses, p.92e.v.) heeft laten zien hoe de relatie tussen woorden en dingen in de $17^{c}$ eeuw fundamenteel anders is dan die van het voorafgaand tijdperk. $\mathrm{H}_{i j}$ vat het zo samen: Het

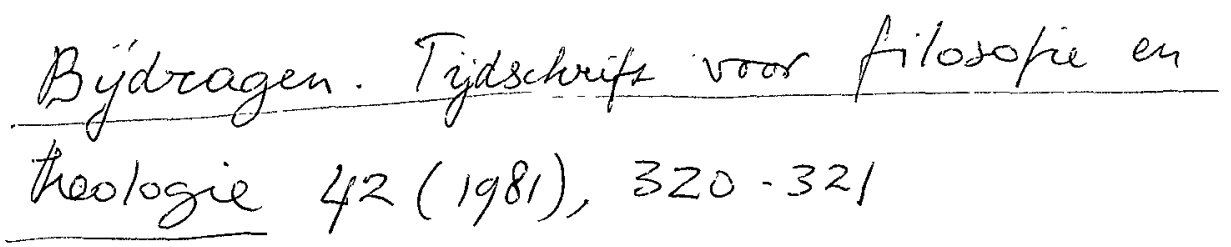


commentaar - dat de taal als zodang ntet bevradgt - heeft plaats gemaakt voor de kritıek - $d w z$ de analyse van het voorstellingsvermogen van de taal - Kritiek betekende in de $17^{e}$ eeuw een neuwe aandacht voor hoe de woorden zich verhouden Dit leidde o a tot grammaticaonderzoek en zelfs tot klankonderzoek (cfr een vru)wel vergeten Nederlander 1635, de Spreeckkonste van Petrus Montanus, bedınaar Goots Woord)

De adndacht voor het Grieks zoals de Jonge beschryft was onderdeel van een hausse in grammatica en filologisch onderzoek (III Het Grieks van het NT, IV filologische verklaring van het NT)

Een onderzoek in hoeverte deze kritiek doorwerkte valt buiten de beperking van de Jonge Toch ontneemt het criterıum "aandacht voor de bujbel in zijn ontstaanstıj" ( 14 r 30 cfr ook p 15 r 30, p 16 r 11, p 17 r 17) te vaak het zicht op de eigen methodes en de eigen invalshoek van de $17^{\mathrm{c}}$ eeuw

Het leesbare en moot uitgevoerde boekje van de Jonge is in zı) beperkingen in alle opzichten een aanwinst voor de geschredenıs van de (Nederlandse') exegese Het toont echter de noodzaak van een meer uitgebreide studie dubbel en dwars aan

Bart-Jan Koet

Staples, Peter The Church of England 1961-1980, (IIMO Research Pamphlet no 3), Utrecht, Heidelberglaan 2, 1981, $17 \times 23,116 \mathrm{blz}, f 7,50$

Dit is een zeer informatıef boekje over recente ontwikkelıngen binnen de Anglikaanse kerk in Engeland Nadat de auteur eerst het te behandelen tıjdvak globaal heeft gekenschetst (1), en geprobeerd heeft de Kerk van Engeland te definıeren en een indruk te geven van haar pluriformiteit (2), ordent hij vervolgens zijn materiaal onder drie hoofden mensen, strukturen en gebouwen (3), het geloof en de praktijk van de Kerk van Engeland (4, daarın worden de konflıktueuze ontwikkelıngen op het terrein van de leer, de moraal en de liturgie beschreven), en tenslotte de externe relaties, $d$ met de andere (onafhankelijke) kerken van de Anglikaanse Communo, met de andere kerken in Engeland en daarbuten, en met de Staat en de Maatschappy (5) Een (zeer korte) epiloog, een beknopte biblıgrafie en een dito lisst van persoonsnamen besluten het werk

De ontwikkeling die zich in deze jaren in de Kerk van Engeland aftekent is nog niet afgesloten, daarom is ook het boekje meer beschrijvend dan evaluatıef Maar ze is wel beslıssend, want een fundamenteel beginsel van het Anglikanisme, nl het beroep op de traditıe van de eerste vif feeuwen, is tengevolge van de nieuwe hermeneutrek op verschillende terreinen zın geldingskracht aan het verliezen

De recensent heeft met interesse gelezen hoe de Kerk van Engeland probeert om binnen haar episkopale struktuur een plaats te geven aan een synodale bestuursvorm (er is sinds 1969 een Generale Synode, met drie 'kamers', die van de bisschoppen, van de clerus en van de leken) Daarbı) is het opmerkelıjk dat in zaken ais de hereniging met de Methodisten en de toelating van de vrouw tot het kerkelijk ambt de bisschoppen progressiever stemden dan de clerus en de leken

Op drie punten werd mijn nieuwsgierigheld net bevredigd wat is nu de etgenheid van de Anglikaanse theologie (in Engeland) in vergelıjking met de kontınentale? in welke lagen van de engelse maatschappi) is de Kerk van Engeland het diepst geworteld' en zıjn er verschijnselen die vergelijkbaar zıjn met wat ten onzent basisbeweging heet?

A H C van Eıjk

Scheele, Paul-Werner Alle Esns, Theologische Bettrage II, Paderborn, Bonfacius Verlag, ISBN 3-87088-205-0, 1979, 15 x 23, $269 \mathrm{blz}$, DM 24,-

Het tweede deel van P.W Scheeles theologische opstellen (vgl Budragen 39(1978)94) onder de tutel Alle eins biedt een uitvoerige ecclesiologie als prolegomenon voor een, in het tweede deel, even uitvoerig geschreven oecumenische theologie Zijn ecclesıologie staat in het teken van de Triniteit vanwaaruit hij ook het principe van een dynamische en concrete eenheid-in-veelheid ontwikkelt dat als gids zal dienen voor het oecumenisch gesprek In her ecclesılogisch gedeelte worden successievelijk de Kerk besproken als mysterte, het tuebehoren tot die in Kerk in alle varıatıe, de binnenkerkelıje dialoog en de na te streven houdingen in deze daloog, de verhouding van kerkelıjke en wereldlıke vooruitgang, de eucharıstie als teken van adnwezige $\mathrm{t} n$ komende eenheid, het leven in de Geest en, daarmee verbonden, de betekenis van het vormsel en tenslotte de vragen rond het ambt en her primaat In het gedeelte over de oecumenische theologie valt de nadruk op de mogelıjkheden van eenheid over de grenzen heen van kerkelijke confessie en op de huidige 